ESTIMATES OF CONSUMPTIVE USE AND GROUND-WATER RETURN FLOW USING WATER BUDGETS IN PARKER VALLEY, ARIZONA AND CALIFORNIA, 1981-84

By Sandra J. Owen-Joyce

U.S. GEOLOGICAL SURVEY

Water-Resources Investigations Report 88-4063

Prepared in cooperation with the

U.S. BUREAU OF RECLAMATION

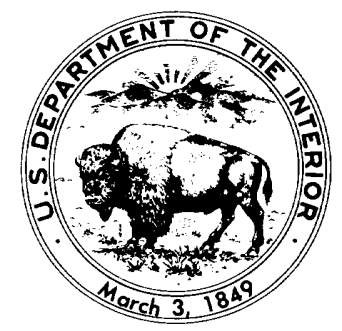




\section{DEPARTMENT OF THE INTERIOR \\ DONALD PAUL HODEL, Secretary}

U.S. GEOLOGICAL SURVEY

Dallas L. Peck, Director

For additional information write to:

U.S. Geological Survey

Box FB-44

Federal Building

300 West Congress Street

Tucson, Arizona 85701-1393
Copies of this report can be purchased from:

U.S. Geological Survey Books and Open-File Reports Section Federal Center, B1dg. 810

Box 25425

Denver, CO 80225 


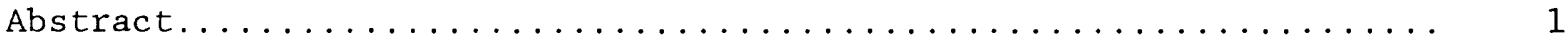

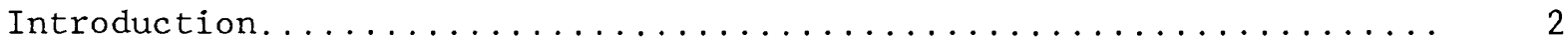

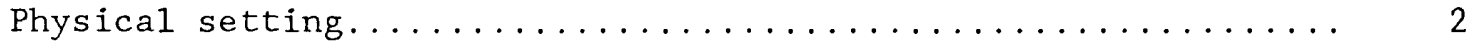

Consumptive-use terminology..................... 4

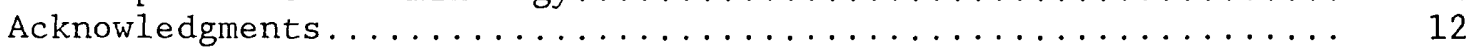

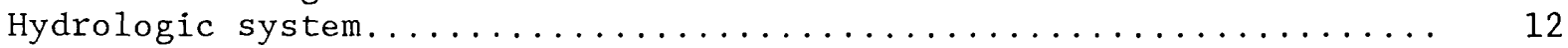

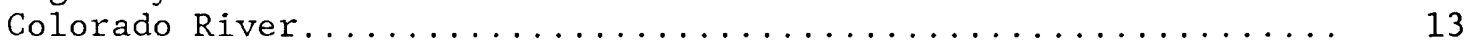

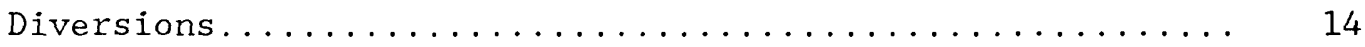

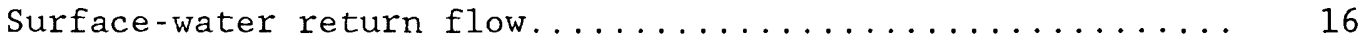

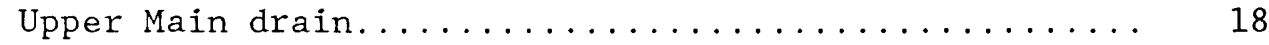

Palo Verde drain........................ 20

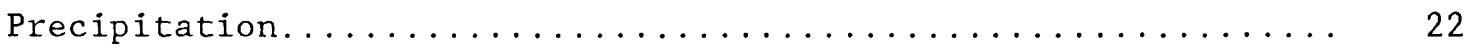

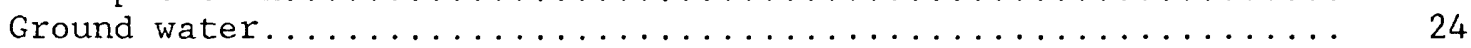

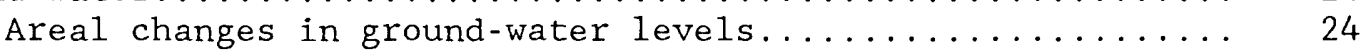

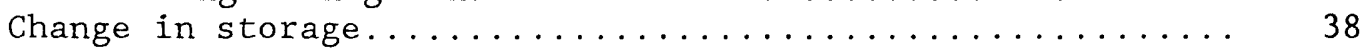

Consumptive use............................. 41

Area drained by drainage ditches.................. 41

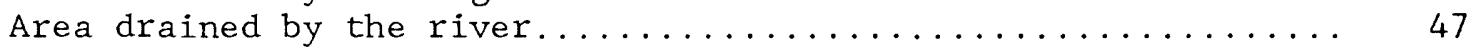

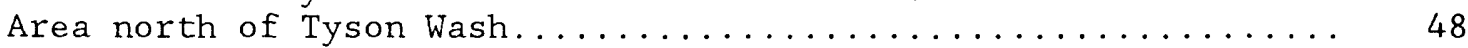

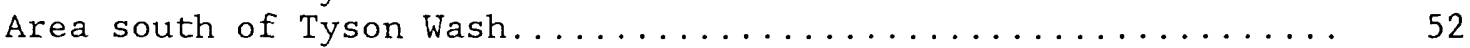

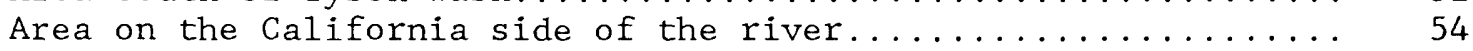

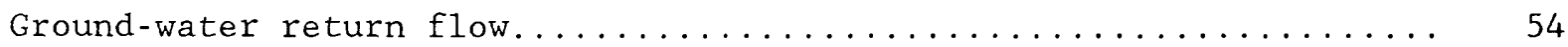

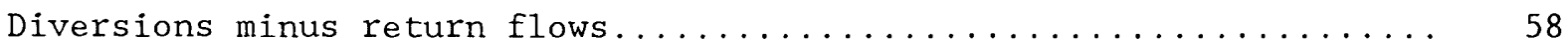

Comparison of consumptive-use estimates................. 59

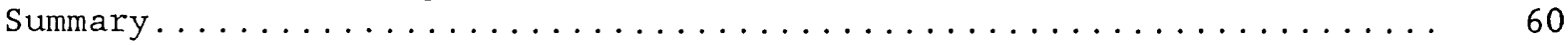

Selected references............................ 62

\section{ILLUSTRATIONS}

Figure 1. Map showing location of study area............. 3

2. Map showing Parker Valley and location of streamflowgaging stations and surface-water measurement sites... 6

3. Graph showing annual total cropped area, diversions, applied water, and return flows in Parker Valley,

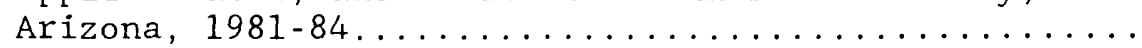

4. Graph showing annual total cropped area, cultivated area, and acreages by crop type in Parker Valley,

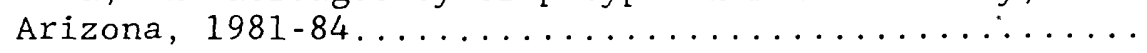

5. Graph showing annual flow in the Colorado River, $1960-84$. 
Figure 6. Graph showing daily mean flow in the Colorado

River below Parker Dam, 1980-84.............. 14

7. Graph showing daily mean gage height of the Colorado River at Parker Cross Section No. 7,

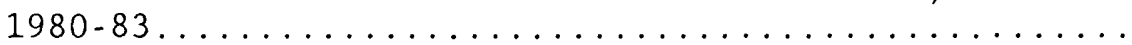

8. Graph showing annual flow diverted at Headgate Rock Dam into the Colorado River Indian Reservatior Main Canal and surface-water return flows to the Colorado River through wasteways and drains in Parker Valley,

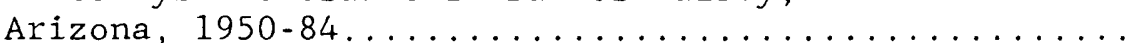

9. Graph showing annual flow in the Colorado River Indian Reservation (CRIR) Main Canal, Colorado River Indian Reservation (CRIR) Lower Main drain, Upper Main drain, and Palo Verde drain in Parker Valley,

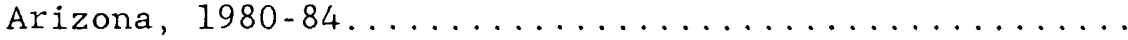

10. Graph showing annual precipitation at Parker, Arizona, $1938-84 \ldots \ldots \ldots \ldots \ldots \ldots \ldots \ldots$

11. Map showing average water-table altitude in Parker Valley, Arizona, $1982 \ldots \ldots \ldots \ldots \ldots \ldots \ldots$

12. Map showing average water-table altitude

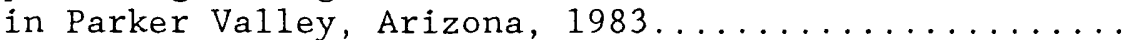

13. Map showing average water-table altitude in Parker Valley, Arizona, 1984...............

14. Map showing water-table altitude in the southern part of Parker Valley,

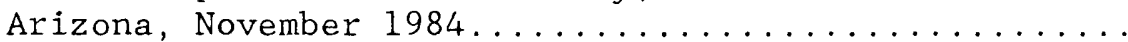

15. Map showing change in annual average ground-water levels in Parker Valley,

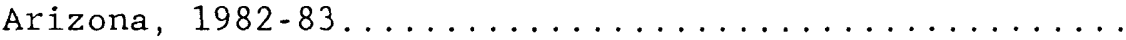

16. Map showing change in annual average ground-water levels in Parker Valley, Arizona, $1983-84 \ldots \ldots \ldots \ldots \ldots \ldots \ldots \ldots \ldots \ldots \ldots$

17. Hydrographs showing water levels in selected wells in northern Parker Valley, Arizona,

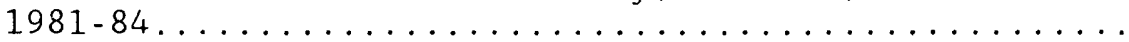

18. Hydrographs showing water levels in selected we1ls south of Poston wasteway in Parker

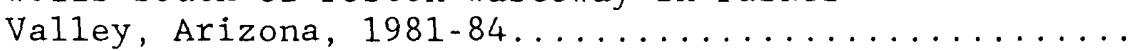

19. Graph showing comparison of consumptive use by vegetation and evapotranspiration in Parker

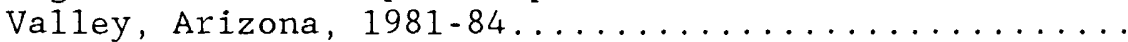

20. Graph showing comparison of consumptive use by vegetation and evapotranspiration per unit vegetated area in Parker Valley, Arizona,

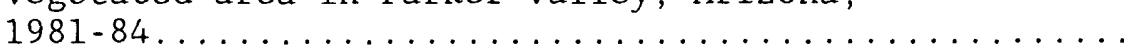

21. Graph showing comparison of consumptive use by vegetation determined from a water budget and consumptive use of Colorado River water determined from diversions minus return flows in Parker Valley, Arizona, 1981-84.............. 
Table 1. Estimates of irrigation requirements and evapotranspiration by vegetation north of Tyson Wash in Parker Valley, Arizona,

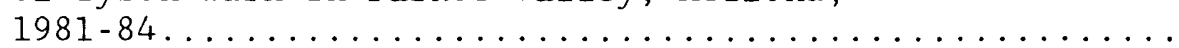

2. Diversions to Parker Valley, Arizona,

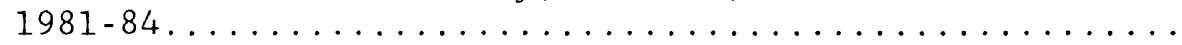

3. Estimates of surface-water return flows to the Colorado River in Parker Valley,

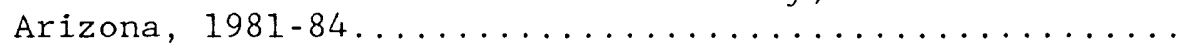

4. Estimates of Colorado River seepage in Palo Verde drain in Parker Valley, Arizona, 1981-84....

5. Annual precipitation for Parker, Arizona,

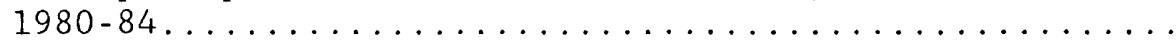

6. Annual water-level changes in the area drained by the Colorado River in

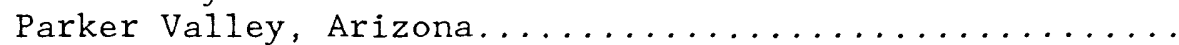

7. Change in ground-water storage for Parker

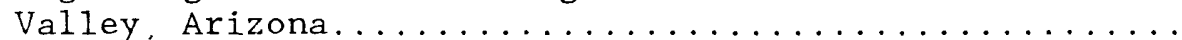

8. Estimates of consumptive use by vegetation in Parker Valley, Arizona, 1981-84..............

9. Water budgets for the area drained by drainage ditches in Parker Valley, Arizona, $1981-84 \ldots \ldots \ldots \ldots \ldots \ldots \ldots \ldots \ldots \ldots \ldots . \ldots \ldots \ldots$

10. Estimates of surface-water diversions to irrigated land north of Tyson Wash in

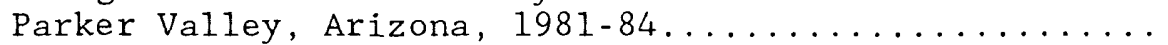

11. Evapotranspiration per unit vegetated area

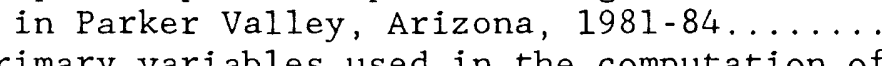

12. Primary variables used in the computation of consumptive use by vegetation and groundwater return flow north of Tyson Wash in Parker Valley, Arizona, and sensitivity of results to a change in specified value............

13. Estimates of surface-water diversions to irrigated land south of Tyson Wash in

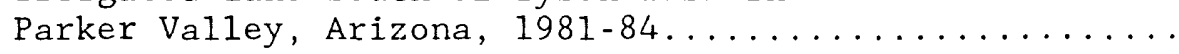

14. Areas by crop type south of Tyson Wash in

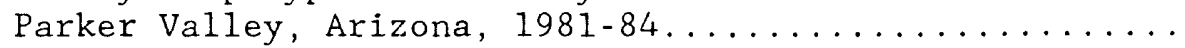

15. Estimates of evapotranspiration and consumptive use by vegetation south of Tyson Wash in

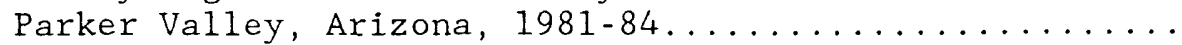

16. Estimates of evapotranspiration and consumptive use by vegetation on the California side of the river in Parker Valley, Arizona, $1984 \ldots \ldots \ldots \ldots \ldots$

17. Water budgets for the area drained by the Colorado River in Parker Valley, Arizona, $1981-84$ 
For readers who prefer to use metric (International System) units rather than inch-pound units, the conversion factors for the terms used in this report are listed below:

\begin{tabular}{|c|c|c|}
\hline Multiply inch-pound u & By & To obtain metric unit \\
\hline inch (in.) & 25.4 & millimeter $(\mathrm{mm})$ \\
\hline foot (ft) & 0.3048 & meter (m) \\
\hline mile (mi) & 1.609 & kilometer $(\mathrm{km})$ \\
\hline square mile $\left(\mathrm{mi}^{2}\right)$ & 2.590 & square kilometer $\left(\mathrm{km}^{2}\right)$ \\
\hline foot per mile $(\mathrm{ft} / \mathrm{mi})$ & 0.1894 & $\begin{array}{l}\text { meter per kilometer } \\
(\mathrm{m} / \mathrm{km})\end{array}$ \\
\hline $\begin{array}{l}\text { foot squared per day } \\
\qquad\left(\mathrm{ft} \mathrm{t}^{2} / \mathrm{d}\right)\end{array}$ & 0.0929 & $\begin{array}{l}\text { meter squared per day } \\
\left(\mathrm{m}^{2} / \mathrm{d}\right)\end{array}$ \\
\hline $\begin{array}{l}\text { cubic foot per second } \\
\left(\mathrm{ft}^{3} / \mathrm{s}\right)\end{array}$ & 0.02832 & $\begin{array}{l}\text { cubic meter per second } \\
\left(\mathrm{m}^{3} / \mathrm{s}\right)\end{array}$ \\
\hline acre & 0.4047 & $\begin{array}{l}\text { square hectometer } \\
\left(\mathrm{hm}^{2}\right)\end{array}$ \\
\hline acre-foot (acre-ft) & 0.001233 & $\begin{array}{l}\text { cubic hectometer } \\
\left(\mathrm{hm}^{3}\right)\end{array}$ \\
\hline $\begin{array}{l}\text { acre-foot per square } \\
\text { mile }\left(\text { acre-ft } / \mathrm{mi}^{2}\right)\end{array}$ & 0.000476 & $\begin{array}{l}\text { cubic hectometer per } \\
\text { square kilometer } \\
\left(\mathrm{hm}^{3} / \mathrm{km}^{2}\right)\end{array}$ \\
\hline
\end{tabular}

Sea level: In this report "sea level" refers to the National Geodetic Vertical Datum of 1929 (NGVD of 1929) -A geodetic datum derived from a general adjustment of the first-order level nets of both the United States and Canada, formerly called "Sea Level Datum of 1929." 


\title{
ESTIMATES OF CONSUMPTIVE USE AND GROUND-WATER RETURN FLOW USING WATER BUDGETS IN PARKER VALLEY, ARIZONA AND CALIFORNIA, 1981-84
}

\author{
By
}

Sandra J. Owen-Joyce

\begin{abstract}
Annual water budgets were used to estimate consumptive use by vegetation (crops and phreatophytes) and ground-water return flow from 1981 to 1984 in Parker Valley, Arizona and California. Consumptive use by vegetation was estimated to be 482,800 acre-feet in $1981,432,000$ acrefeet in 1982, 413,500 acre-feet in 1983, and 420,900 acre-feet in 1984 on the Arizona side of the Colorado River. Consumptive use by vegetation was estimated to be 45,400 acre-feet in 1984 on the California side of the river. Ground-water return flow from the area north of Tyson Wash in Arizona was estimated to be 0 acre-feet in 1981, 1983, and 1984 and 1,900 acre-feet in 1982. No ground-water return flow occurred from the area south of Tyson Wash and on the California side of the river; consumptive use by vegetation in those areas exceeded the measured diversion of river water to croplands because of the additional evapotranspiration by phreatophytes.
\end{abstract}

Water-budget estimates of consumptive use by vegetation were compared to estimates of evapotranspiration and estimates of consumptive use of Colorado River water calculated as measured diversions minus surface-water and ground-water return flows. Evapotranspiration was calculated as the sum of products of areas of vegetation types and wateruse rates. Estimates of evapotranspiration were from 1 percent less to 9 percent higher than estimates of consumptive use by vegetation in the area north of Tyson Wash. The percentage differences in the two estimates were within the measurement errors of the two major measured components in the water budget, regardless of differences in year-to-year conditions.

Estimates of consumptive use of Colorado River water calculated as measured diversions minus return flows were consistently lower than estimates of consumptive use by vegetation. Variations in tributary inflow and river stage are not accounted for in the calculation of measured diversions minus return flows, and induced seepage from the river to replace ground water transpired by phreatophytes is not accounted for as a diversion. Estimates of consumptive use of Colorado River water were from 18 to 37 percent lower than estimates of consumptive use by vegetation. 


\section{INTRODUCTION}

A decree by the U.S. Supreme Court (1964) apportions the waters of the lower Colorado River to the States of California, Arizona, and Nevada in terms of consumptive use, which is defined in the decree as $" * * *$ diversions from the stream less such return flow thereto as is available for consumptive use* $* *$." The decree requires that, for each diverter, the quantities of diversion and consumptive use be published annually.

Ground-water return flow is estimated in order to credit the States with total return flows from their diversions. The quantity of ground-water return flow is needed in order to estimate consumptive use as defined by the decree. Consumptive use of lower Colorado River water was estimated as diversions minus surface-water and ground-water return flows. Diversions and surface-water return flows were measured. Ground-water return flow cannot be measured but was estimated from a water budget for part of the area in Parker Valley, Arizona (Leake, 1984) and Palo Verde Valley, California (Owen-Joyce, 1984).

The U.S. Geological Survey, in cooperation with the U.S. Bureau of Reclamation, is developing a new method of calculating consumptive use and apportioning it to lower Colorado River water users. The Colorado River between Parker Dam and Imperial Dam (fig. 1) is being used as a test site for the proposed new method. The estimate of consumptive use calculated from a surface-water budget (streamflow depletion) will be compared to the estimate of consumptive use calculated as diversions minus surface-water and ground-water return flows. Consumptive use calculated as diversions minus return flows was estimated separately for each of the three valleys in the Parker Dam to Imperial Dam reach.

This report is one of three reports and describes that part of the study that estimated consumptive use by vegetation (crops and phreatophytes) and ground-water return flow in Parker Valley for calendar years 1981, 1982, 1983, and 1984 using a modified version of the method described by Leake (1984). Included in this report are (1) a brief description of the hydrologic system, (2) estimates of consumptive use by vegetation and ground-water return flow determined from water budgets, (3) estimates of evapotranspiration, (4) a comparison of estimates of evapotranspiration to estimates of consumptive use by vegetation, (5) estimates of consumptive use of river water calculated as measured diversions minus return flows, and (6) a comparison of the estimates of consumptive use by vegetation to estimates of consumptive use of river water as measured diversions minus return flows. All annual data given in this report are for calendar years.

\section{Physical setting}

Parker Valley contains about $205 \mathrm{mi}^{2}$ of Colorado River flood plain in western La Paz County, Arizona, and eastern Riverside County, California 


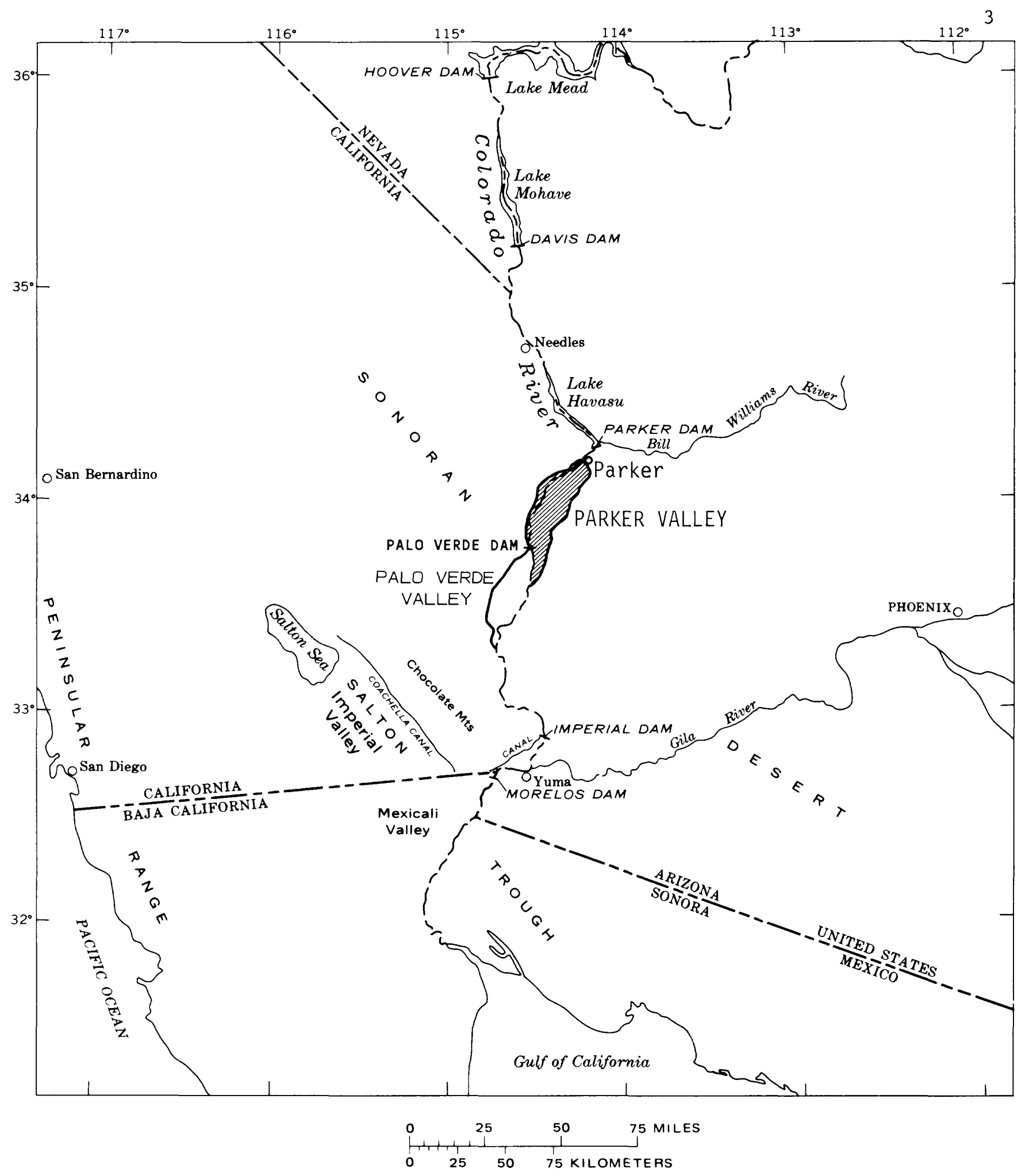

Figure 1.--Location of study area (shaded). 
(fig. 1). Most of Parker Valley lies within the Colorado River Indian Reservation. The main population center is Parker, Arizona (fig. 2). Most of the flood plain is used for agriculture. About 77,000 acres are cultivated and some fields are double cropped annually. All crops are irrigated because the average annual precipitation of 3.82 in. (Sellers and Hill, 1974, p. 358) is insufficient for growing crops. About 30,000 acres are covered with phreatophytes.

Diversions to Parker Valley, the mixture of crops grown, and river stage changed from 1980 to 1984. Diversions to the valley varied particularly during 1983 (fig. 3). In 1983 and 1984 no double cropping was reported by the U.S. Bureau of Indian Affairs (written commun., 1985). During 1983 and to a smaller extent in 1984, the Federal government instituted the PIK (Payment-In-Kind) program in which cotton growers were subsidized for not planting as much as half of their usual cotton acreage. The largest change in the crop mixture occurred during 1983 because of the PIK program (fig. 4). Many of the fields left fallow in 1983 were irrigated and cultivated to preserve soil structure. Volunteer vegetation grew in response to irrigation and cultivation but no records were kept on the quantity of volunteer vegetation that grew. In 1984 the area of fallow fields was within 200 acres of the area in 1982. Diversions to the valley and applied water varied from year to year and followed the same trend as the total cropped area (fig. 3). Flow in the river exceeded downstream requirements for part of 1980 and for 1983 and 1984.

Principal crops in Parker Valley were cotton, alfalfa, and small grair:s (mostly wheat with some rye or barley). Most of the "other crops" included melons, spring and fall lettuce, bermuda, sudan, and milo with some garlic, onions, tomatoes, and maize. Cotton was the main crop by acreage in 1981 and 1982, whereas alfalfa was the main crop by acreage in 1983 and 1984 (table 1). Second crops included cotton, milo, melons, and fall lettuce that followed spring lettuce, wheat, and melons (Raymond and Rezin, 1986, p. 3).

Principal phreatophytes in Parker Valley were mesquite and arrowweed with some saltcedax, saltbush, cottonwood, and willow. Phreatophytes comprised from 25 to 31 percent of the vegetated area from 1981 to 1984; vegetated area includes the cropped area (areas from fields with double crops are counted twice) and the area of phreatophytes (table 1).

\section{Consumptive-Use Terminology}

The results of each of three methods of estimating water use were given different terms to distinguish one from another and for the purpose of comparison. In Parker Valley water is used mainly for agriculture; therefore, the largest percentage of each of the three water-use values is agricultural water use. Water also is consumptively used by phreatophytes and as a domestic and municipal supply. Water diverted from the river is applied to crops. Some of the diverted water is used by crops and some of 
the unused water that percolates to the water table is used by phreatophytes prior to being discharged into drainage ditches or the river. Water use by crops and phreatophytes cannot be separated; therefore, it is collectively referred to as water used by vegetation.

Consumptive use by vegetation is the loss of water from an area through evapotranspiration and evaporation from bare-soil (nonvegetated areas or fallow irrigated fields) and open-water surfaces (excluding the river). An estimate of consumptive use by vegetation for part of the valley is needed in order to estimate ground-water return flow. Consumptive use by vegetation is calculated from a ground-water budget. Consumptive use by vegetation for that part of the shallow alluvial aquifer drained by drainage ditches may be expressed as:

$$
C U v_{d}=S W D_{d}+P_{\text {eff }}+G W I F+R O_{t r}+S_{c r}-S W R F-P-\Delta S_{d} \text {, }
$$

where

$$
\begin{aligned}
& C U v_{d}=\text { estimated consumptive use by vegetation, in acre-feet, in } \\
& S W D_{d}=\text { that part of the measured surface-water diversion ( } S W D \text { ), } \\
& P_{\text {eff }}=\text { effective precipitation, in acre-feet; } \\
& \text { GWIF = ground-water inflow, in acre-feet, from the area east of } \\
& \begin{aligned}
R O_{t r}= & \text { tributary runoff, in acre-feet, from the area east of the } \\
& \text { flood plain. }
\end{aligned} \\
& S_{c r}=\text { seepage, in acre-feet, from the Colorado River; } \\
& S W R F=\text { measured surface-water return flow, in acre-feet, to the }
\end{aligned}
$$

Evapotranspiration is the loss of water from a land area through transpiration by vegetation and evaporation from the soil surface under the vegetation. Estimates of evapotranspiration were used to adjust the $C U v_{d}$ for use in the area drained by the river. The percentage difference in 


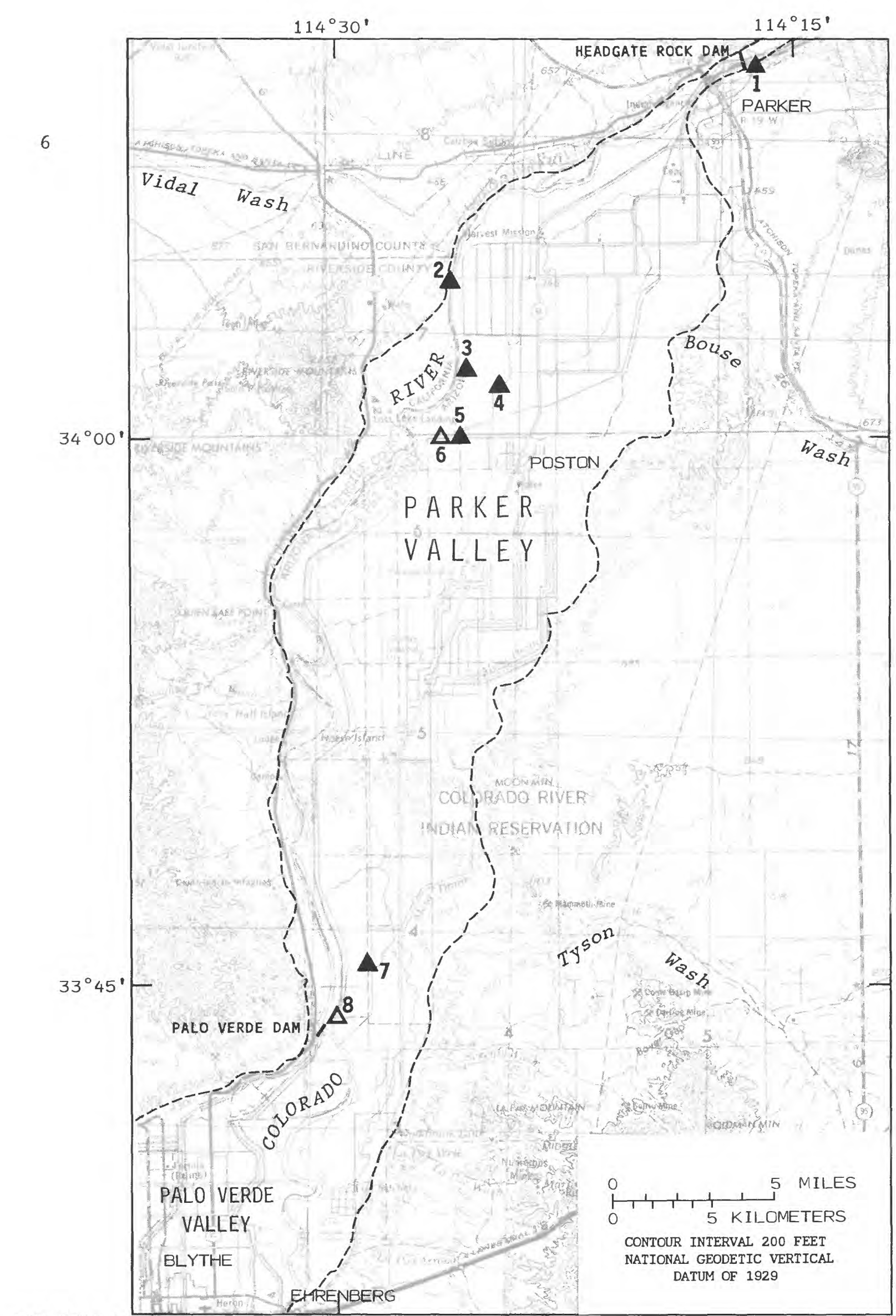

BASE FROM U.S. GEOLOGICAL SURVEY $1: 250,000$ SALTON SEA, 1959-69 AND NEEDLES, 1959-69

Figure 2.--Parker Valley and location of streamflow-gaging stations and surface-water measurement sites. 


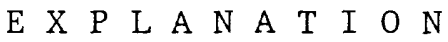

$\hat{1}$

CONTINUOUS-RECORD STREAMFLOW-GAGING STATION-Number, 1 , corresponds to station names listed below

$\frac{\Delta}{6}$

MEASUREMENT SITE-Number, 6, corresponds to site names listed below

COLORADO RIVER FLOOD-PLAIN BOUNDARY

Index of gaging stations and measurement sites

1. Colorado River Indian Reservation Main Canal near Parker

2. Colorado River at Parker Cross Section No. 7

3. Gardner lateral spill near Parker

4. Upper Main drain near Poston

5. Poston wasteway spill gates

6. Poston wasteway near Poston

7. Colorado River Indian Reservation Lower Main drain near Parker

8. Palo Verde drain near Parker

Colorado River below Parker Dam-Gaging station located 14 miles upstream from Headgate Rock Dam (this station does not have a number because it is

located outside of the map area) 


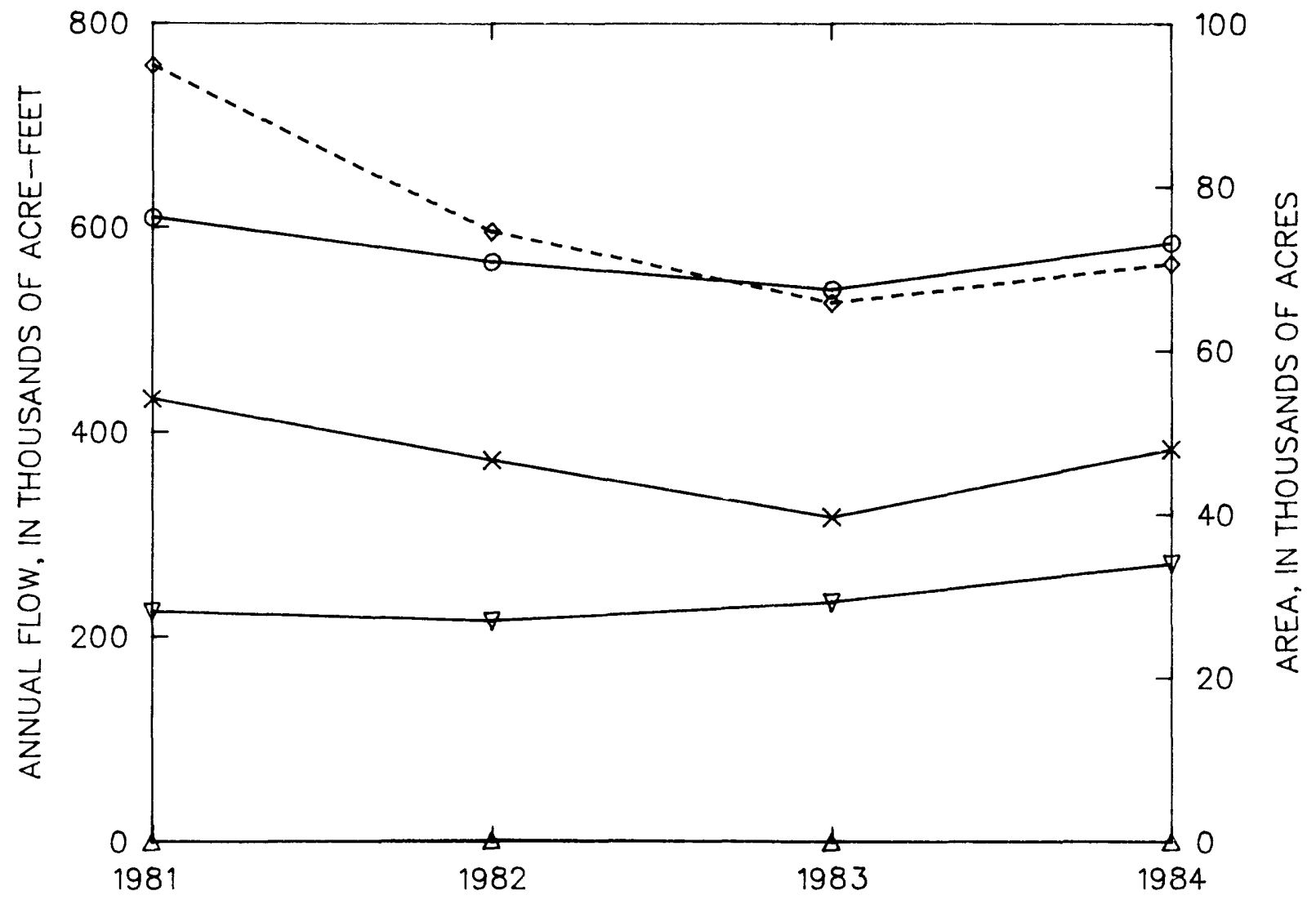

EXPLANATION

AREA

$\diamond-\cdots \quad$ Total crops

FLOW

$\odot$ Diverted irrigation water

$\lessdot$ Applied irrigation water

$\gtrless$ Surface-water return flow

$\triangle \quad$ Ground-water return flow

Figure 3.--Annual total cropped area, diversions, applied water, and return flows in Parker Valley, Arizona, 1981-84. 


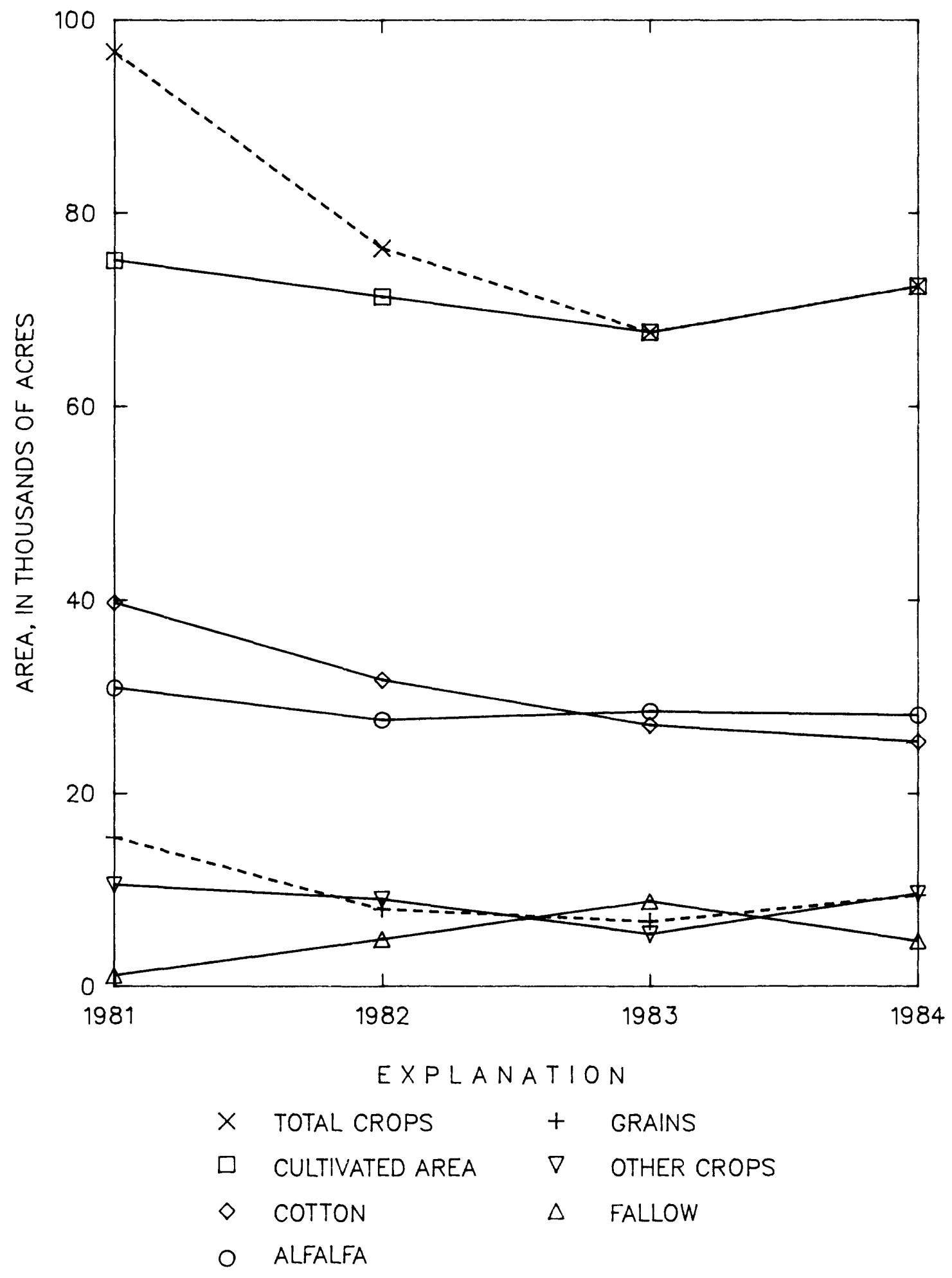

Figure 4.--Annual total cropped area, cultivated area, and acreages by crop iype in Parker Valley, Arizona, 1981-84. 


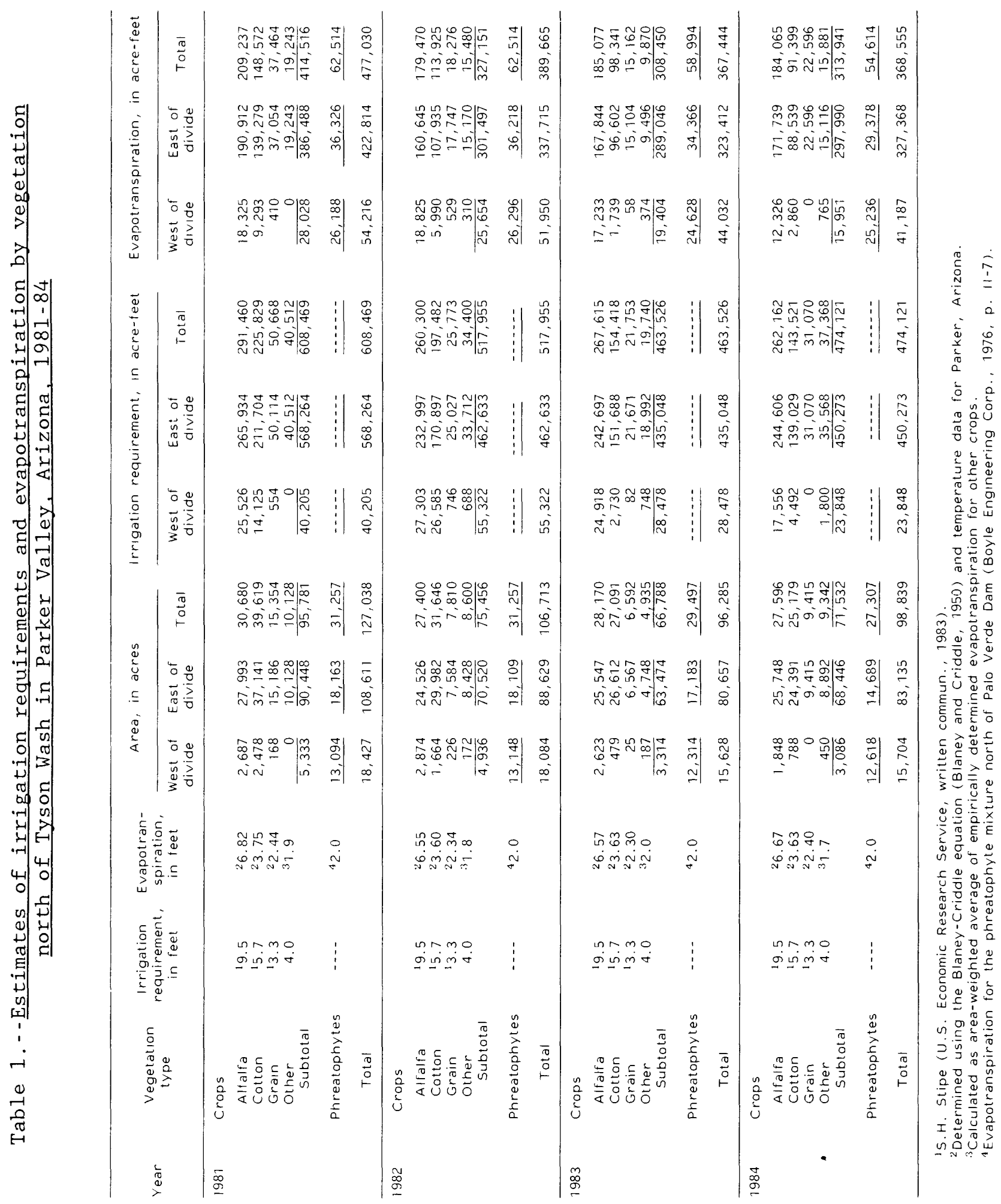


evapotranspiration between the two drainage areas was assumed to apply to the estimates of consumptive use by vegetation and reflects the difference in the distribution of vegetation types in the two drainage areas. Evapotranspiration may be expressed as:

$$
E T=\Sigma A \times W u
$$

where

$$
\begin{aligned}
& E T \quad=\text { estimated evapotranspiration, in acre-feet; } \\
& A \quad=\text { the area, in acres, of each vegetation type; and } \\
& W u \quad=\text { water-use rate, in feet, for that vegetation type. }
\end{aligned}
$$

Consumptive use of Colorado River water is the loss of water from the Colorado River defined by the decree (see section of report entitled "Introduction" for definition) and may be expressed as:

$$
C U_{C r}=S W D-S W R F-G W R F,
$$

where

$$
\begin{aligned}
C U_{C r}= & \text { estimated consumptive use, in acre-feet, of Colorado River } \\
& \text { water; } \\
S W D= & \text { measured surface-water diversion, in acre-feet, from the } \\
& \text { river; } \\
S W R F= & \text { measured surface-water return flow, in acre-feet, to the } \\
& \text { Colorado River from the drainage ditches; and } \\
G W R F= & \text { estimated ground-water return flow, in acre-feet, to the } \\
& \text { river. }
\end{aligned}
$$

Consumptive use of Colorado River water is accounted for annually by the U.S. Bureau of Reclamation (1982; 1984; 1985; 1986) as measured diversions minus measured return flows while a method for estimating unmeasured return flows was being developed.

Ground-water return flow is estimated from a ground-water budget for that part of the shallow alluvial aquifer drained by the river and may be expressed as:

$$
G W R F=S W D_{r}+P_{\text {eff }}-C U v_{r}-\Delta S_{r}
$$

where

$$
\begin{aligned}
S W D_{r}= & \text { that part of the measured surface-water diversion }(S W D), \\
& \text { in acre-feet, from the river applied to irrigated land in } \\
& \text { the area drained by the river; } \\
P_{e f f}= & \text { effective precipitation, in acre-feet; } \\
C U v_{r}= & \text { estimated consumptive use by vegetation, in acre-feet, in } \\
& \text { the area drained by the river; and } \\
\Delta S_{r}= & \text { change in ground-water storage, in acre-feet, in the } \\
& \text { shallow alluvial aquifer in the area drained by the river. }
\end{aligned}
$$


Acknowledgments

Conrad B. Kresge, Bill Martin, and Tom Claw of the U.S. Bureau of Indian Affairs provided irrigation and agricultural data. Hydrologic and crop data were collected by the U.S. Bureau of Indian Affairs and included regulatory waste to drainage ditches, irrigation-water deliveries to the area south of Tyson Wash, and acreages by crop type in the area south of Tyson Wash.

\section{HYDROLOGIC SYSTEM}

In Parker Valley the hydrologic system includes the highly regulated Colorado River and a shallow alluvial aquifer that underlies the flood plain. River water is diverted into a system of canals for distribution to fields on the flood plain. Ground water discharges to drainage ditches and to the river. Drainage ditches lower the water table beneath cropland and maintain it at sufficient depths to reduce waterlogging and damage to crops. The Colorado River and the drainage ditches are in hydraulic connection with ground water in the shallow aquifer. When releases from the reservoirs satisfy downstream water requirements, most of the reach adjacent to the irrigated areas north of Poston wasteway gains water from the aquifer. Most of the reach adjacent to areas of phreatophytes south of Poston wasteway loses water to the aquifer. When the annual average river stage rises, some of the gaining reaches of the river can become losing reaches, particularly where the ground-water divide is close to the river.

When flow in the river is regulated to meet downstream requirements, drainage ditches and the application of irrigation water to fields control saturated thickness in the aquifer and direction of groundwater movement through the aquifer. Water is diverted from the river into canals from which some water spills back to the river or into drainage ditches (regulatory waste), some enters the aquifer as canal seepage, some evaporates, and the rest is applied to fields. Applied water is consumptively used by crops or recharges the aquifer through deep percolation. Deep percolation of irrigation water causes mounding of the water table under the fields and creates shallow ground-water divides between drainage ditches and between drainage ditches and the river. In the area drained by drainage ditches, ground water discharges into ditches where it flows to the Colorado River as surface-water return flow. In the area drained by the river, ground water drains to the river as ground-water return flow. Some ground water is intercepted and consumed by phreatophytes, and some ground water is pumped for municipal and domestic use. Other sources of recharge to the aquifer are ground-water inflow from areas that border the flood plain and infiltration of runoff from tributary areas. Precipitation is insufficient for recharge; however, precipitation that falls on the vegetation is available for consumptive use.

South of Poston wasteway, the river loses water directly to the aquifer through seepage and ground water moves away from the river and into the drainage ditch about $0.5 \mathrm{mi}$ east of the river. Whether ground water 
flows out of the flood plain into bordering areas north of Tyson Wash is unknown because water-level data are not available for the area drained by drainage ditches. In the area south of Tyson wash, ground water moves away from the river and out of the flood plain into bordering areas.

\section{Colorado River}

Flow in the Colorado River is controlled by a series of dams upstream from Parker Valley. Releases from Parker Dam, about $14 \mathrm{mi}$ upstream from the north end of Parker Valley (fig. 1), satisfy most downstream water and flood-control requirements. Annual releases from 1960 to 1984 ranged from 6.3 to 20.5 million acre-ft (fig. 5). Flows in 1980, 1983, and 1984 exceeded downstream requirements because water was released for flood control. From 1960 to 1984, annual flow in the Colorado River at Palo Verde Dam near the south end of Parker Valley ranged from 5.1 to 18.3 million acre-ft (fig. 5). The decrease in flow between the two gages indicates the diversion and consumptive use of Colorado River water.

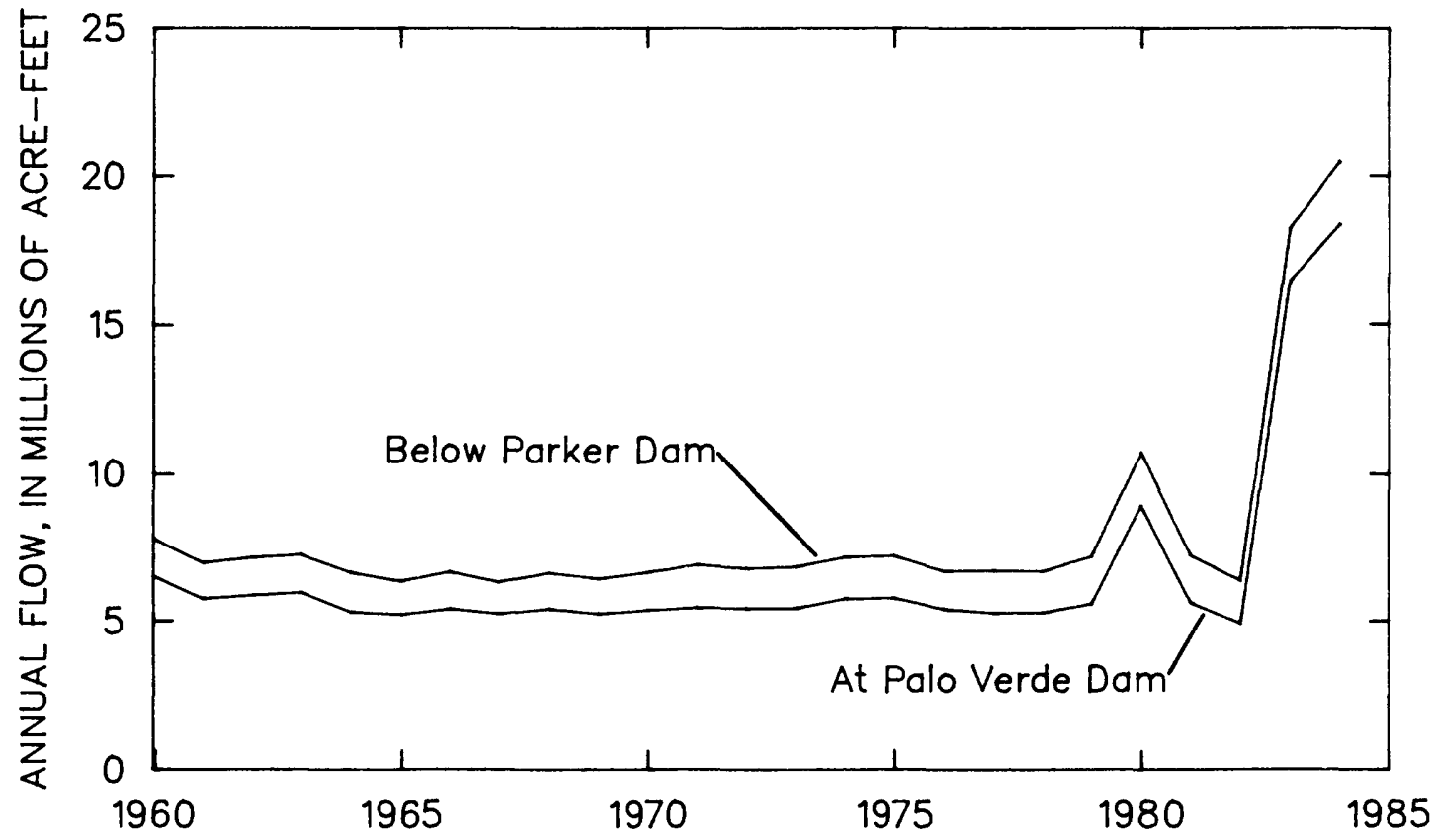

Figure 5.--Annual flow in the Colorado River, 1960-84.

Flow in the Colorado River varies daily, seasonally, yearly, and from place to place along the river. Releases of water for irrigation and power generation, diversions, evapotranspiration, spillage from canals, and return flows to the river contribute to daily fluctuations in flow. Seasonal variations occur because releases from Parker Dam are highest in summer when the irrigation needs are greatest such as in 1981 and 1982 
(fig. 6). During the latter half of 1980 and in 1983 and 1984 , flood-control releases from Parker Dam dominated, and seasonal variations did not occur.

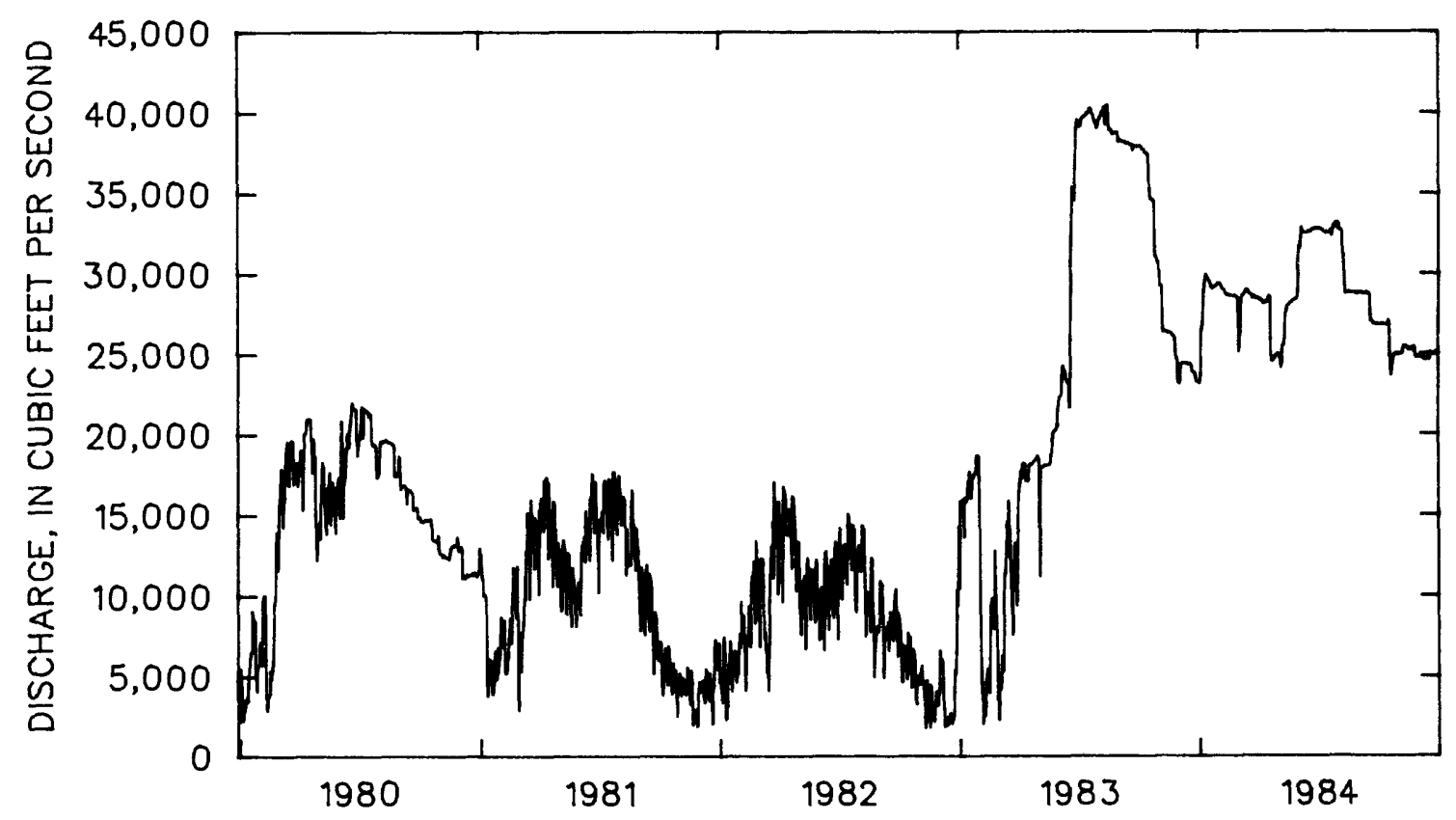

\section{Figure 6.--Daily mean flow in the Colorado River below Parker Dam, 1980-84.}

Changes in river stage in the Colorado River correlate with changes in flow (figs. 6 and 7). Changes in river stage cause fluctuations in ground-water levels beneath the flood plain and in the quantity of ground water in storage. The river is hydraulically connected to ground water in the alluvium. River stage was higher in 1983 and 1984 than it was in 1982, as was shown for the reach adjacent to Palo Verde Valley (OwenJoyce and Kimsey, 1987, fig. 8). The same relation exists in Parker Valley but cannot be shown because increases in flow in May 1983 (fig. 6) began to wash out the gages in the river adjacent to Parker Valley. River-stage data are incomplete because data collection stopped when the recorders were removed to prevent the loss of equipment (fig. 7).

\section{Diversions}

Headgate Rock Dam is a diversion structure for most of the irrigation water supplied to the Colorado River Indian Reservation (CRIR) on the Arizona side of the river (fig. 2). The annual diversion of water at Headgate Rock Dam into the CRIR Main Canal ranged from 209,700 to 677,300 acre-ft between 1950 and 1984 ( $\mathrm{fig}$. 8). The records for the gaging station on the canal are rated excellent or within 5 percent. Water is 


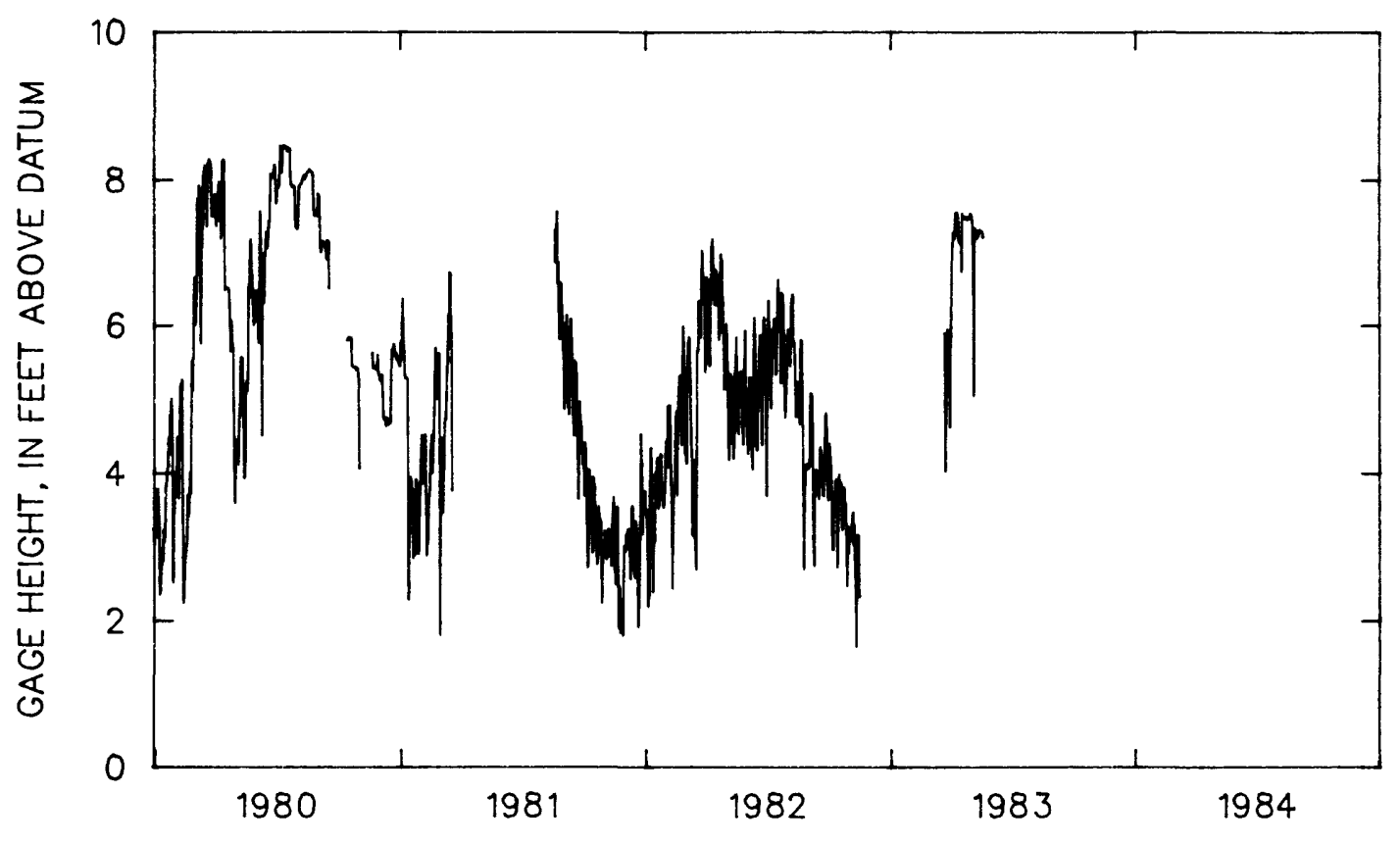

Figure 7.--Daily mean gage height of the Colorado River at Parker Cross Section No. 7, 1980-83.

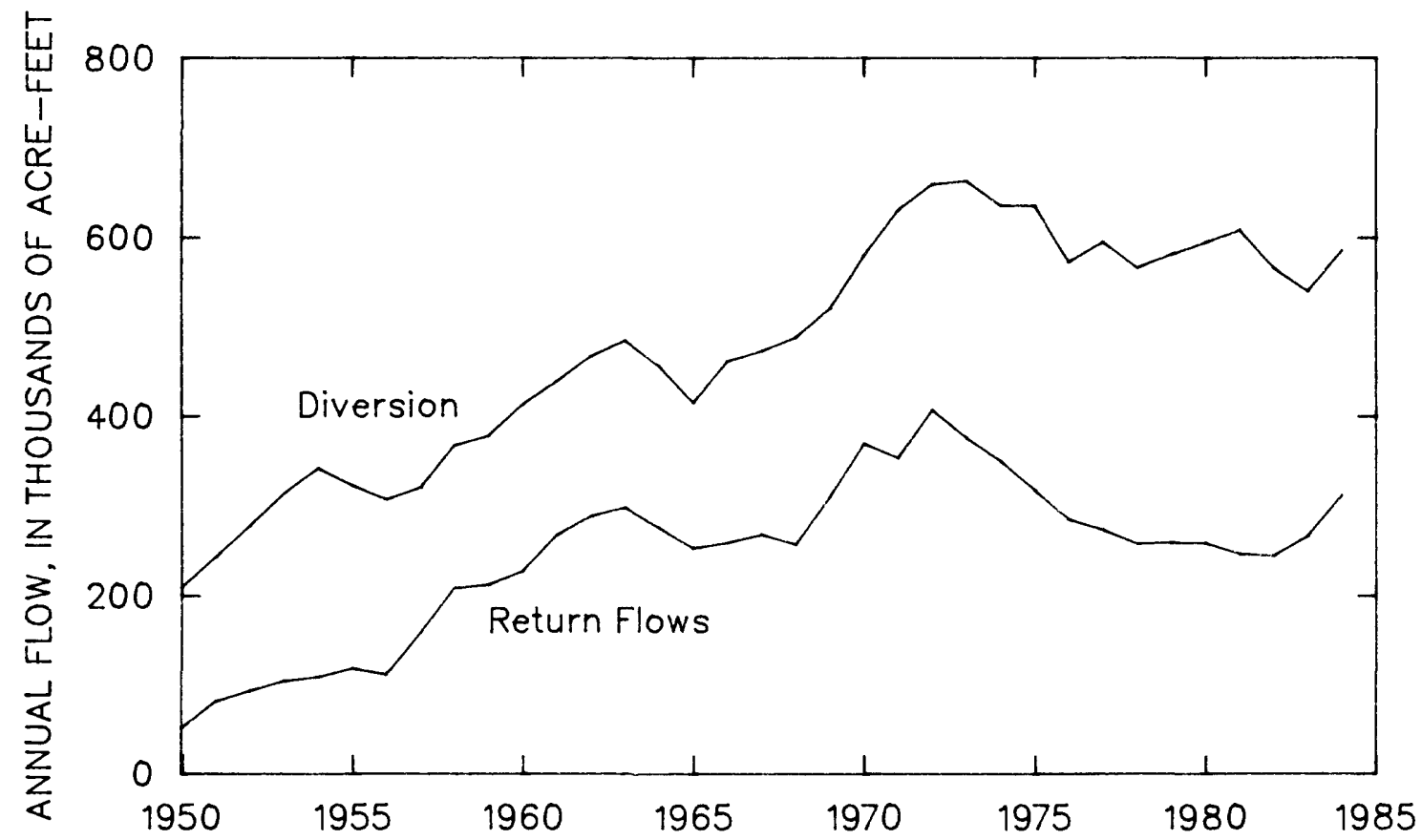

Figure 8.--Annual flow diverted at Headgate Rock Dam into the Colorado River Indian Reservation Main Canal and surfacewater return flows to the Colorado River through wasteways and drains in Parker Valley, Arizona, 1950-84. 
pumped at various other sites along the river and applied to local irrigated areas in Arizona and California, some of which are on the reservation ( $t a b 1 e$ 2). The use of pumps about 1 mi upstream from Palo Verde Dam was suspended in 1982 when canals were completed that bring water from the diversion at Headgate Rock Dam.

\section{Surface-Water Return Flow}

Surface-water return flow includes water that spills from canals, laterals, and wasteways and ground water that returns to the river in about $120 \mathrm{mi}$ of open-channel drainage ditches (Bill Martin, U.S. Bureau of Indian Affairs, oral commun., 1984). Surface-water return flow to the Colorado River ranged from 51,400 to 407,600 acre-ft between 1950 and 1984 (fig. 8). Surface-water return flow was computed at two canal spillways and three drainage ditches (fig. 2) for 1981 to 1984 (table 3). Records for the gaging stations on the drainage ditches are rated good to fair or within 10 to 15 percent. A11 three stations on the drainage ditches are affected by backwater when flows in the river exceed downstream requirements. Use of the total surface-water return flow in the water budget, summed as in table 3 , assumes that all the flow originated from the diversion at Headgate Rock Dam and does not consider seepage from the river. Seepage enters the drainage ditches especially during high flows in the river.

Flow in the drainage ditches (drains) originates as return flow from applied irrigation water, seepage from the river, and tributary ground-water and surface-water inflows. The estimates of annual tributary inflows are small in comparison to irrigation return flows and river seepage; quantification of tributary inflows in the drains is difficult. During years when flow in the river was regulated to meet downstream requirements, 1960 to 1979 (fig. 5), most of the flow in the drains was irrigation return flows with smaller amounts of river seepage. During high-flow years-1980, 1983, and 1984 (fig. 6) -river seepage increased and became a more significant component.

Changes in flow in the drainage ditches generally follow the same trend as the changes in the diversion at Headgate Rock Dam (fig. 8). On a year-to-year basis, however, diversions and return flows do not follow the same trend-for example, from 1954 to 1955,1967 to 1968,1970 to 1971, 1972 to 1973,1974 to 1975,1976 to 1977,1980 to 1981 , and 1982 to 1983 (fig. 8). An expansion of the plots from 1980 to 1984 of the individual drains compared to the diversion shows that flow in the drains decreased from 1980 to 1981 as the diversion increased, and flow in all the drains increased from 1982 to 1983 when the diversion decreased (fig. 9).

Decreased flow in the drains between 1980 and 1981 indicates an effect caused by a decrease in flow in the river rather than an effect caused by increased diversion (fig. 9). Decrease in flow in the river corresponds to a decrease in stage (fig. 7), movement away from the river of the ground-water divide between the river and the westernmost drainage ditch, an increase in the area drained by the river, and bank storage returning to the river rather than moving through the alluvium to discharge into the drains. 
Table 2.--Diversions to Parker Valley, Arizona, 1981-84, in acre-feet per year

\begin{tabular}{|c|c|c|c|c|}
\hline & 1981 & 1982 & 1983 & 1984 \\
\hline \multicolumn{5}{|l|}{ Diversions $^{1}$ : } \\
\hline Headgate Rock Dam ${ }^{2}$ & 608,100 & 566,300 & 539,500 & 584,800 \\
\hline $\begin{array}{l}\text { Colorado River Indian } \\
\text { Reservation pumps }\end{array}$ & 1,542 & 0 & 0 & 0 \\
\hline $\begin{array}{l}\text { Colorado River Indian } \\
\text { Reservation pumps }\end{array}$ & 13,780 & 10,950 & 6,461 & 8,955 \\
\hline Clayton/Raynor pumps 5 & 4,916 & 4,916 & 1,830 & 936 \\
\hline Clayton/Raynor wel16 & 280 & 280 & 374 & 1,266 \\
\hline $\begin{array}{l}\text { Total Arizona } \\
\text { diversion (rounded) }\end{array}$ & $\underline{\underline{628,600}}$ & $\underline{\underline{582,400}}$ & $\underline{\underline{548,200}}$ & 596,000 \\
\hline $\begin{array}{l}\text { Colorado River Indian } \\
\text { Reservation pumps } \\
\text { and wells }\end{array}$ & 14,046 & 3,407 & 3,430 & 3,670 \\
\hline $\begin{array}{l}\text { Colorado River Indian } \\
\text { Reservation Big River } \\
\text { wel18 }\end{array}$ & 1,402 & 2,339 & 2,224 & 890 \\
\hline R.L. Lye we $11^{9}$ & 108 & 108 & $\ldots \ldots$ & 60 \\
\hline $\begin{array}{l}\text { Pascal and Ludwig } \\
\text { Engineering pump } 10\end{array}$ & $\ldots \ldots$ & 146 & $\ldots \ldots$ & $\ldots \ldots$ \\
\hline $\begin{array}{l}\text { Total California } \\
\text { diversion (rounded) }\end{array}$ & 15,600 & 6,000 & 5,700 & 4,600 \\
\hline TOTAL DIVERSIONS & 644,200 & 588,400 & 553,900 & 600,600 \\
\hline
\end{tabular}

${ }^{1}$ U.S. Bureau of Reclamation (1982; 1984; 1985; 1986).

${ }^{2}$ Gaged by the U.S. Geological Survey, Colorado River Indian Reservation Main Canal near Parker.

${ }^{3}$ About 1 mi upstream from Palo Verde Dam.

${ }^{4}$ About $3 \mathrm{mi}$ downstream from Palo Verde Dam.

${ }^{5}$ About $6.5 \mathrm{mi}$ downstream from Palo Verde Dam.

${ }^{6}$ Pumping from wells on the flood-plain aquifer is considered use of Colorado River water.

${ }^{7}$ Various sites located in the 13 -mile reach north of Palo Verde Dam.

${ }^{8}$ About $7 \mathrm{mi}$ downstream from Headgate Rock Dam.

${ }^{9}$ About $25 \mathrm{mi}$ upstream from Palo Verde Dam and $1.7 \mathrm{mi}$ west of the river.

${ }^{10}$ About $10 \mathrm{mi}$ upstream from Palo Verde Dam. 
Table 3.--Estimates of surface-water return flows to the Colorado River in Parker Valley, Arizona, 1981-84, in acre-feet per year

\begin{tabular}{|c|c|c|c|c|}
\hline Site number ${ }^{1}$ & 1981 & 1982 & 1983 & 1984 \\
\hline $\begin{array}{l}\text { Gardner lateral } \\
\quad \text { spill }\end{array}$ & 741 & 1,190 & 696 & 1,760 \\
\hline $\begin{array}{l}\text { Poston wasteway } \\
\text { spil1 gates }\end{array}$ & $\underline{21,190}$ & 27,390 & $\underline{32,100}$ & $\underline{38,880}$ \\
\hline $\begin{array}{l}\text { Subtotal of surface-water } \\
\text { return flows that spill } \\
\text { from canals (rounded) }\end{array}$ & 21,900 & 28,600 & 32,800 & 40,600 \\
\hline $\begin{array}{l}\text { Poston wasteway } \\
\text { from Upper Main } \\
\text { drain }\end{array}$ & 73,520 & 67,650 & 74,200 & 79,920 \\
\hline Palo Verde drain & 27,120 & 24,930 & 30,310 & 48,170 \\
\hline $\begin{array}{l}7 \quad \mathrm{CRIR}^{3} \text { Lower } \\
\text { Main drain }\end{array}$ & $\underline{124,200}$ & $\underline{123,400}$ & $\underline{129,400}$ & 143,700 \\
\hline $\begin{array}{l}\text { Subtotal of surface-water } \\
\text { return flows from the } \\
\text { drainage system (rounded) }\end{array}$ & 224,800 & 216,000 & $\underline{\underline{233}, 900}$ & 271,800 \\
\hline $\begin{array}{l}\text { Total surface-water } \\
\text { return flows (rounded) }\end{array}$ & 246,700 & 244,600 & 266,700 & 312,400 \\
\hline
\end{tabular}

${ }^{1}$ Site number corresponds to locations shown on figure 2 .

${ }^{2}$ Equal to Poston wasteway minus Poston wasteway spill gates.

${ }^{3}$ Colorado River Indian Reservation.

${ }^{4}$ Assumes all the flow originated from the diversion at Headgate Rock Dam.

Between 1982 and 1983, increased flow in the drains was associated with a decrease in the quantity of water diverted (fig. 9) during the PIK program. All the drains had an increase in flow, which correlated with the rise in flow in the river (fig. 6) because of flood-control releases. From 1983 to 1984, the diversion as well as flow in the river and drains increased.

Upper Main drain.--Flow is measured in Upper Main drain about $3.5 \mathrm{mi}$ upstream from the mouth (fig. 2, site 4) because of a backwater problem near the mouth. Flow at this site originates from irrigation return flow even during high-flow years because the ground-water divide 


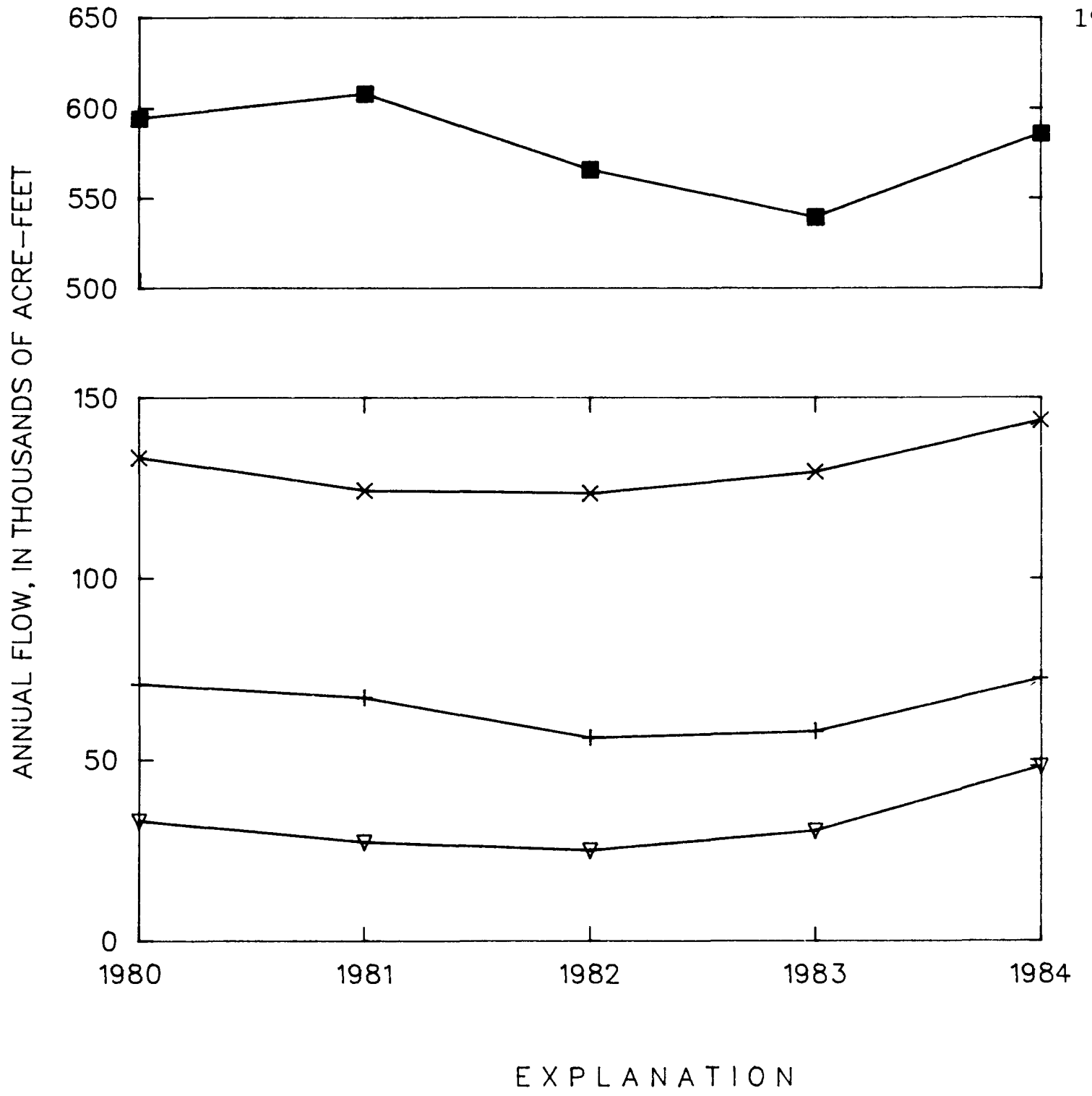

DIVERSION

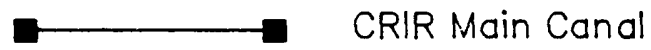

RETURN FLOWS

$\longleftarrow \quad$ CRIR Lower Main drain

$\longrightarrow$ Upper Main drain

$\longmapsto$ Palo Verde drain

Figure 9.--Annual flow in the Colorado River Indian Reservation (CRIR) Main Canal, Colorado River Indian Reservation (CRIR) Lower Main drain, Upper Main drain, and Palo Verde drain in Parker Valley, Arizona, 1980-84. 
1 ies between this site and the river (see figs. 11-13 in the section entitled "Ground Water" for the location of the ground-water divide). Upper Main drain empties into Poston wasteway about $100 \mathrm{ft}$ below the canal spill gates. Flow that reaches the river at Poston wasteway is computed as the sum of the flow in Upper Main drain (fig. 2, site 4), estimates of inflow from small tributary drains to Upper Main drain below site 4, and the flow discharged through the spill gates into the wasteway. The increase in flow between site 4 and the wasteway originates from irrigation return flow and seepage from the river. The largest difference in flow between the two sites, about 16,000 acre-ft, occurred in 1983 when the river had the largest annual rise.

Palo Verde drain.--Flow in Palo Verde drain originates from two sources-irrigation return flow and seepage from the Colorado River. Palo Verde drain parallels the river about $1 \mathrm{mi}$ east. The quantity of river seepage intercepted by Palo Verde drain cannot be precisely determined. Annual quantities of river seepage in the drain can be estimated, following the method of Leake (1984, p. 8), as shown in table 4.

Leake (1984, p. 8) estimated that irrigation return flow from about 10,000 acres of cropland drained into Palo Verde drain in 1981. Total cropped area varied from year to year. In order to incorporate changes in irrigation return flow with changes in the total cropped area, the 10,000 acres estimated by Leake was varied in this analysis to reflect the percentage change in the total cropped area east of the divide from year to year (table 4). Most of the changes in total cropped area from year to year are caused by changes in double-cropped area and changes in cotton acreage as a result of the PIK program. A small part of the change in total cropped area is related to the movement of the ground-water divide.

When flow in the river is regulated to meet downstream requirements, it follows seasonal flow patterns and river stage varies little from year to year. Under these conditions, the quantity of irrigation return flow that discharges into the drainage system per unit irrigated area can be calculated by dividing the surface-water return flow from the drainage system (table 3 ) by the total cropped area east of the divide (table 1). Irrigation return flow per cropped area that discharged into the drainage system was calculated in this study to be $2.49 \mathrm{ft}$ in 1981 and $3.06 \mathrm{ft}$ in 1982 (table 4). During years when flow in the river is high because of releases at Parker Dam for flood control, more water seeps into the aquifer and discharges into the drainage system. In 1983 and 1984, irrigation return flow per cropped area that discharged into the drainage system was calculated to be 3.68 and $3.97 \mathrm{ft}$, respectively (table 4). The larger quantities of irrigation return flow per cropped area during years of high flow indicate larger quantities of river seepage in the drainage system.

Irrigation return flow from the area that drains to Palo Verde drain was estimated as the product of the total cropped area that drains to Palo Verde drain and irrigation return flow per cropped area in 1981 and 1982 (table 4). Values for irrigation return flow per cropped area for 1983 and 1984 cannot be used because they include river seepage; therefore, irrigation return flow in 1983 and 1984 was calculated using irrigation 
Table 4. - Estimates of Colorado River seepage in Palo Verde drain in

Parker Valley, Arizona, 1981-84

\begin{tabular}{lcccc}
\hline & 1981 & 1982 & 1983 & 1984 \\
\hline $\begin{array}{l}\text { Irrigation return flow per unit } \\
\text { cropped area, in acre-feet/acre }\end{array}$ & 2.49 & 3.06 & $\mathbf{2 3 . 6 8}$ & $\mathbf{2 3 . 9 7}$ \\
$\begin{array}{l}\text { Percent reduction in cropped } \\
\text { area east of divide from } \\
\text { previous year }\end{array}$ & & & & \\
$\begin{array}{l}\text { Cropped area, in acres, that } \\
\text { drains to Palo Verde drain }{ }^{3}\end{array}$ & $\mathbf{4} 10,000$ & 7,800 & 7,020 & 7,582 \\
$\begin{array}{l}\text { Irrigation return flow, in } \\
\text { acre-feet, from the area } \\
\text { that drains to Palo Verde } \\
\text { drain (rounded) }\end{array}$ & & & & \\
$\begin{array}{l}\text { River seepage, in acre-feet, } \\
\text { in Palo Verde drain } \\
\text { (rounded) }\end{array}$ & 524,900 & 623,900 & 621,500 & 623,200 \\
\hline
\end{tabular}

${ }^{1} \mathrm{Calculated}$ as surface-water return flows from the drainage system (table 3 ) divided by the total crops east of the divide (table 1 ).

${ }^{2}$ Includes river seepage because of high flows in the river during 1983 and 1984.

${ }^{3}$ Assumes the percent reduction from the previous year for the area east of the divide is uniform over the area.

${ }^{4}$ Leake (1984, p. 8).

${ }^{5}$ Cropped area that drains to Palo Verde drain multiplied by irrigation return flow per cropped area in 1981.

${ }^{6}$ Annual cropped area that drains to Palo Verde drain multiplied by irrigation return flow per cropped area in 1982.

${ }^{7} \mathrm{Calculated}$ as surface-water return flows from Palo Verde drain (table 3 ) minus irrigation return flow from the area that drains to Palo Verde drain.

return flow per cropped area for 1982. The value for 1982 was selected because 1982 had the least amount of double-cropped area-about 5,000 acres compared to 22,000 acres in 1981. No double cropping was reported in 1983 and 1984, which were the years of the PIK program.

River seepage in Palo Verde drain was calculated as the difference between flow in the drain (table 3 ) and the estimate of irrigation return flow from the area that drains to Palo Verde drain. Estimated river seepage for 1981 and 1982 was 2,900 and 1,100 acre-ft, respectively, and these estimates agree with the assessment by Leake (1984, p. 10) that 
intercepted river seepage probably was on the order of several thousand acre-feet or less. The small quantities also correlate with the orientation of the water-table altitude contours for 1981 (Leake, 1984, fig. 5) and 1982 (see fig. 11 in the section entitled "Ground Water") that indicate the largest component of flow west of the drain was parallel to the river. River seepage was 8,800 and 25,000 acre-ft in 1983 and 1984, respectively. Contours of water-table altitude in 1983 (see fig. 12 in the section entitled "Ground Water") and 1984 (see fig. 13 in the section entitled "Ground Water") generally parallel the drain and indicate that the largest component of flow west of the drain was toward the drain. After more than a year of sustained high flow in the river, river seepage in Palo Verde drain became large enough to impact the calculation of consumptive use by vegetation.

\section{Precipitation}

Precipitation provides a small quantity of water, some of which is available for consumptive use by vegetation. Precipitation as a source of recharge to the aquifer is assumed to occur when the mean annual precipitation exceeds 8 in. (Metzger and Loeltz, 1973, p. 35). Annual precipitation at Parker, Arizona, ranged from 0.36 to 12.60 in. between 1938 and 1984 ( $\mathrm{fig} .10$ ), and mean annual precipitation was 4.52 in. On the average about one-third of the precipitation occurs from May to September.

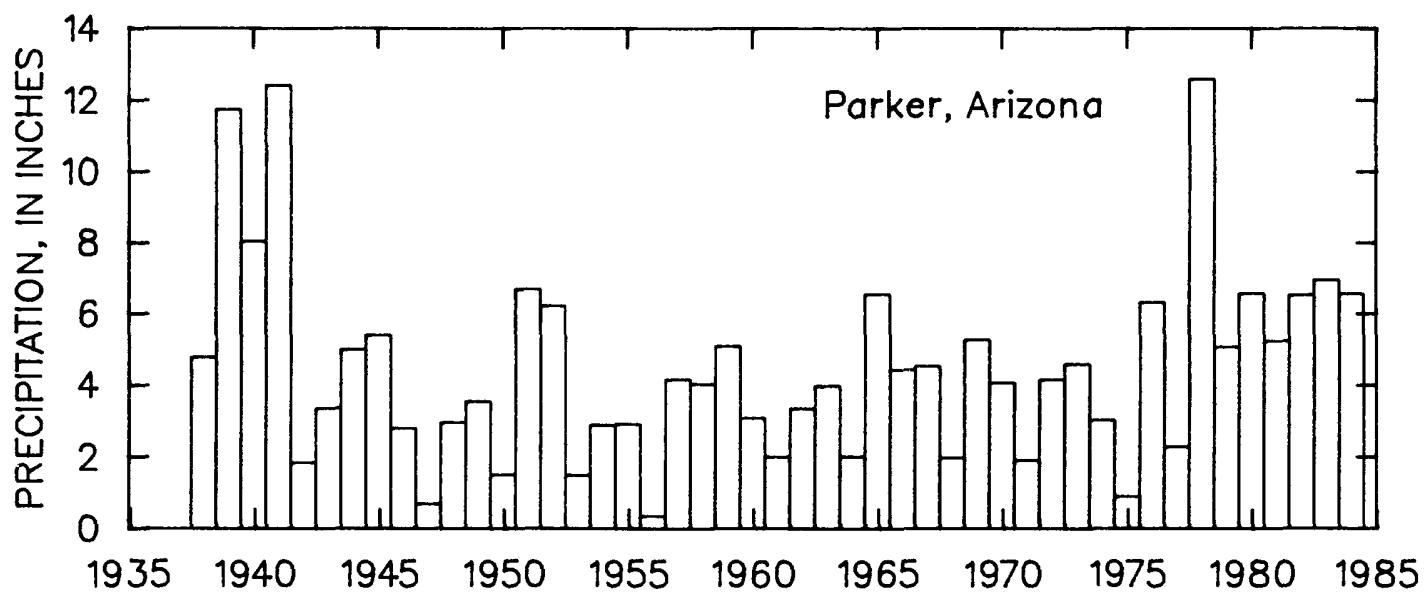

Figure 10.--Annual precipitation at Parker, Arizona, 1938-84.

Effective precipitation was used as a measure of the quantity of precipitation available for consumptive use by vegetation in the water budgets. Effective precipitation may be expressed as:

$$
P_{\text {eff }}=p_{\text {eff }}\left(A_{c}+A_{p}\right) \text {, }
$$


where

$$
\begin{aligned}
& P_{\text {eff }}=\text { effective precipitation, in acre-feet; } \\
& P_{\text {eff }}=\text { annual effective precipitation, in feet; } \\
& A_{C}=\text { cultivated area, in acres; and } \\
& A_{p}=\text { the area, in acres, of phreatophytes. }
\end{aligned}
$$

Annual effective precipitation may be expressed as:

$$
p_{\text {eff }}=\Sigma\left(\frac{R F_{0.25}}{12}\right) \text {, }
$$

where

$$
\begin{aligned}
R F_{0.25} & =\text { effective rainfall per storm, in inches } \\
& =\left(\begin{array}{cl}
R F-0.25 & \text { if } R F>0.25 \\
0 & \text { if } R F<0.25
\end{array}\right.
\end{aligned}
$$

and

$$
R F=\text { total rainfall per storm, in inches. }
$$

Estimates of annual effective precipitation (table 5) were made by summing rainfall that was in excess of 0.25 in. per storm (U.S. Bureau of Reclamation, Lower Colorado River Region, Yuma Project Office, oral commun., 1986) as a means of estimating the quantity of precipitation available to vegetation that could affect the consumptive use of Colorado River water. Annual effective precipitation from 1980 to 1984 (table 5) was computed from weather records for Parker, Arizona (National Climatic Data Center, 1980-84).

Table 5.--Annual precipitation for Parker, Arizona, 1980-84, in inches

\begin{tabular}{lcc}
\hline & \multicolumn{2}{c}{ Precipitation } \\
\cline { 3 - 3 } Year & Effective & Total \\
& & \\
1980 & 3.99 & 10.56 \\
1981 & 2.85 & 5.23 \\
1982 & 3.98 & 6.51 \\
1983 & 3.18 & 6.96 \\
1984 & 2.06 & 2.79 \\
\hline
\end{tabular}


Ground Water

The flood plain of Parker Valley on the Arizona side of the river was divided into two ground-water drainage areas using contours of annual average water-table altitude to determine the location of the ground-water divide between the river and the westernmost drainage ditch (Leake, 1984, p. 14). North of Palo Verde Dam, ground water west of the divide drains to the river and ground water east of the divide drains to drainage ditches. Annual average water-table altitudes were determined by averaging monthly water levels in 49 wells, stage measurements at 2 sites on Palo Verde drain, and water levels in piezometers installed along the river north of Poston wasteway.

Water-table contours indicate that the ground-water divide did not move significantly from 1981 to 1983 at the north end of the valley where the orientation was west-southwest to east-northeast. In 1984, the divide moved as much as $0.4 \mathrm{mi}$ closer to the river. North of Poston wasteway, the divide had the greatest amount of movement where the orientation generally was north to south (figs. 11-13; Leake, 1984, fig. 5) and the location of gaining and losing reaches varied from year to year. In 1981 and 1982, some irrigated area south of Poston wasteway drained to the river. In 1984, a smaller part of this irrigated area drained to the river and in 1983, none of the area drained to the river. Between Poston wasteway and Palo Verde Dam, most of the river lost water to the aquifer where the water either was consumed by phreatophytes between the river and Palo Verde drain or was intercepted by the drain (Leake, 1984, p. 8).

No drainage ditches exist south of Tyson Wash in Parker Valley, and water-level data from 1964 (Metzger and others, 1973, p1. 5) show that ground water flowed away from or parallel to the river. In order to delineate the south boundary of the area drained by drainage ditches, water levels were measured in available wells in November 1984 in the area south of Mesa drain. Water-level data in the area south of Tyson Wash show that ground water still flows away from or parallel to the river (fig. 14). No wells could be measured between Mesa drain and Tyson Wash. Part of this area drains to Mesa drain and part drains south under Tyson Wash, but without water-level data the ground-water divide cannot be delineated. For this study, Tyson Wash was used as the south boundary of the area drained by drainage ditches.

\section{Areal Changes in Ground-Water Levels}

Ground-water levels vary from place to place and year to year along the river. Changes in annual average water levels were determined by subtracting the annual average water-table altitude of one year from that of the following year. Maps showing annual changes in average water levels were prepared using a 1-foot contour interval (figs. 15 and 16). Contours were drawn for the area between the river and Upper Main drain north of Poston wasteway and between the river and Lower Main drain for about $6 \mathrm{mi}$ south of Poston wasteway. Changes in annual average water levels could be shown only for 1982-83 and 1983-84 because the installation of the observation wells was not completed until June 1981. Changes in annual average water levels for the area drained by the river are listed in table 6 . 
Table 6. - Annual water-level changes in the area drained by the Colorado River in Parker Valley. Arizona, in feet

\begin{tabular}{lccc}
\hline Year & $\begin{array}{c}\text { Maximum } \\
\text { decline }\end{array}$ & $\begin{array}{c}\text { Maximum } \\
\text { rise }\end{array}$ & $\begin{array}{c}\text { Average } \\
\text { water-1eve1 } \\
\text { change }\end{array}$ \\
\hline $1980-1981$ & $(1)$ & $(1)$ & $(1)$ \\
$1981-1982$ & $(1)$ & $(1)$ & $(1)$ \\
$1982-1983$ & -0.40 & 3.94 & 2.0 \\
$1983-1984$ & 0.00 & 3.55 & 1.2 \\
\hline
\end{tabular}

${ }^{1}$ No water-level data available.

In the area between the river and the westernmost drainage ditch, the changes in ground-water levels are controlled mainly by changes in river stage. Higher flow in the river in 1983 than in 1982 (fig. 6) caused water levels to rise in the aquifer along the river in 1983. Water levels within about $0.5 \mathrm{mi}$ of the river rose more than $4 \mathrm{ft}$ from 1982 to 1983 (fig. 15). Water levels declined about $1 \mathrm{ft}$ along and within about $1 \mathrm{mi}$ of the northern part of Upper Main drain, in a small area west of Poston, and in the area north of wells P47 and P48. In 1984 flow in the river was maintained at high levels similar to 1983 (fig. 6). From 1983 to 1984, water levels rose as much as $3 \mathrm{ft}$ over most of the area, with some local declines of $1 \mathrm{ft}$ in a small area along the northern part of Upper Main drain and a small area north of well P47 (fig. 16). Water levels declined along Upper Main drain. These declines could be related to the PIK program. Some fields in this area had crops in 1982 and were fallow in 1983 .

Changes in ground-water levels in areas between drainage ditches are controlled by changes in the quantity of irrigation water applied to fields. Water-level declines in the area west of Poston and near wells $P 47$ and $P 48$ probably were caused by variations in the quantity of applied irrigation water. Less irrigation water was applied to fields in 1983 than in 1982. Several areas that had crops in 1982 were fallow in 1983 because of the PIK program. More irrigation water was applied to fields in 1984 than in 1983, and water levels rose in most of the area. In two localized areas west and southwest of Poston, water levels rose as much as $3 \mathrm{ft}$. These local changes probably were caused by water being applied to areas that were fallow in 1983 and cropped in 1984. A change from a crop type with a low irrigation requirement to one with a high irrigation requirement also could contribute to water-level rises.

Hydrographs for selected wells in northern Parker Valley show water-level changes from June 1981 through 1984 and show the relation between location and water-level changes (fig. 17). We1ls P9 and P10 are 0.1 and $0.5 \mathrm{mi}$ from the river, respectively, and are between the river and the ground-water divide. Water-level changes in wells P9 and P10 correlate 


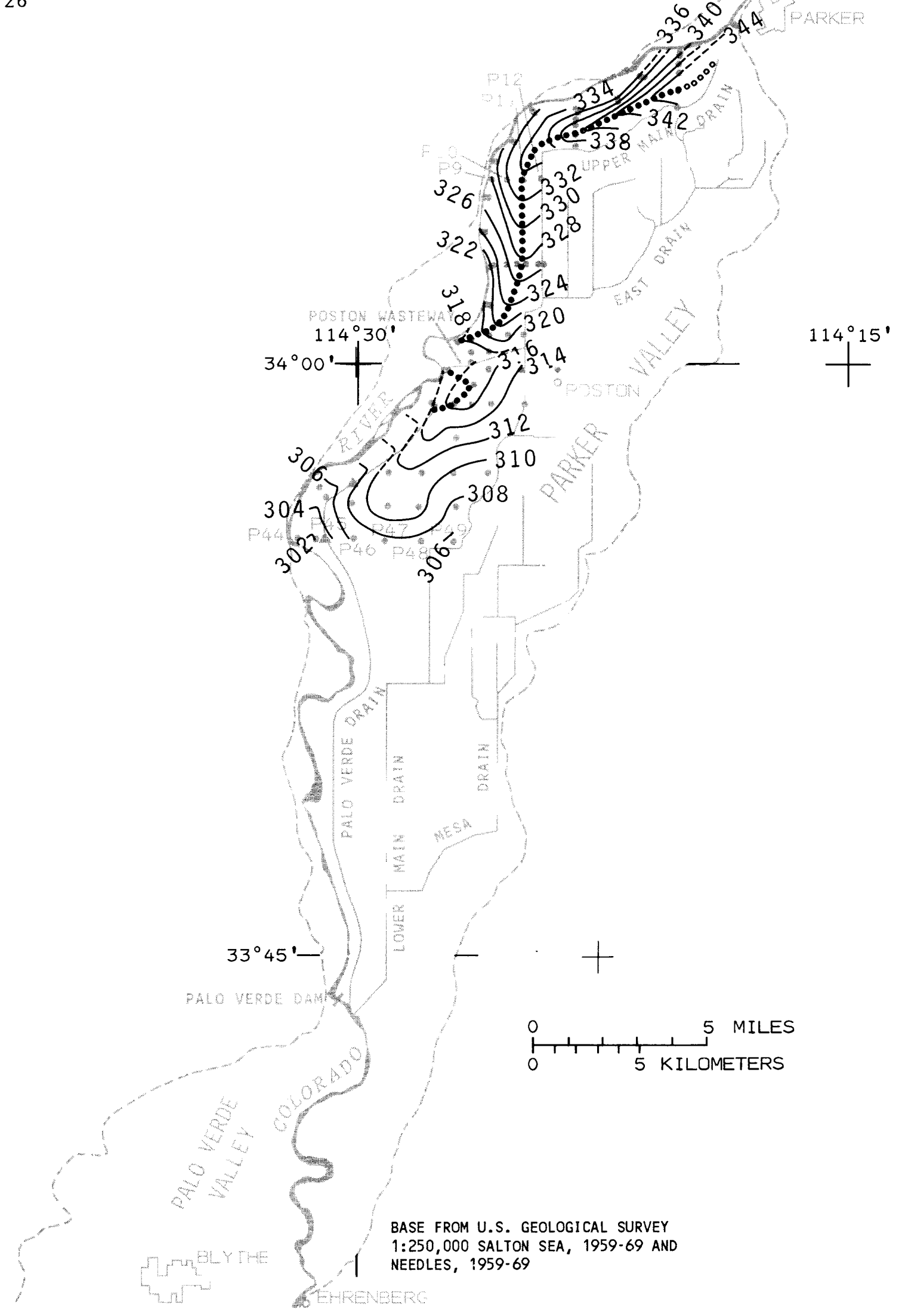

Figure 11.--Average water-table altitude in Parker Valley, Arizona, 1982. 
310 WATER-TABLE CONTOUR-Shows average altitude of water table, 1982. Dashed where approximately located. Contour interval 2 feet. Datum is sea level

SHALLOW OBSERVATION WELL OR PIEZOMETER-Number, P47, is a well number that corresponds to the hydrographs on figures 17 and 18

A STAGE-MEASUREMENT SITE

DRAINAGE DITCH

GROUND-WATER DIVIDE BETWEEN THE COLORADO RIVER AND DRAINAGE DITCHES-Open symbol where approximately located

COLORADO RIVER FLOOD-PLAIN BOUNDARY

Figure 11 


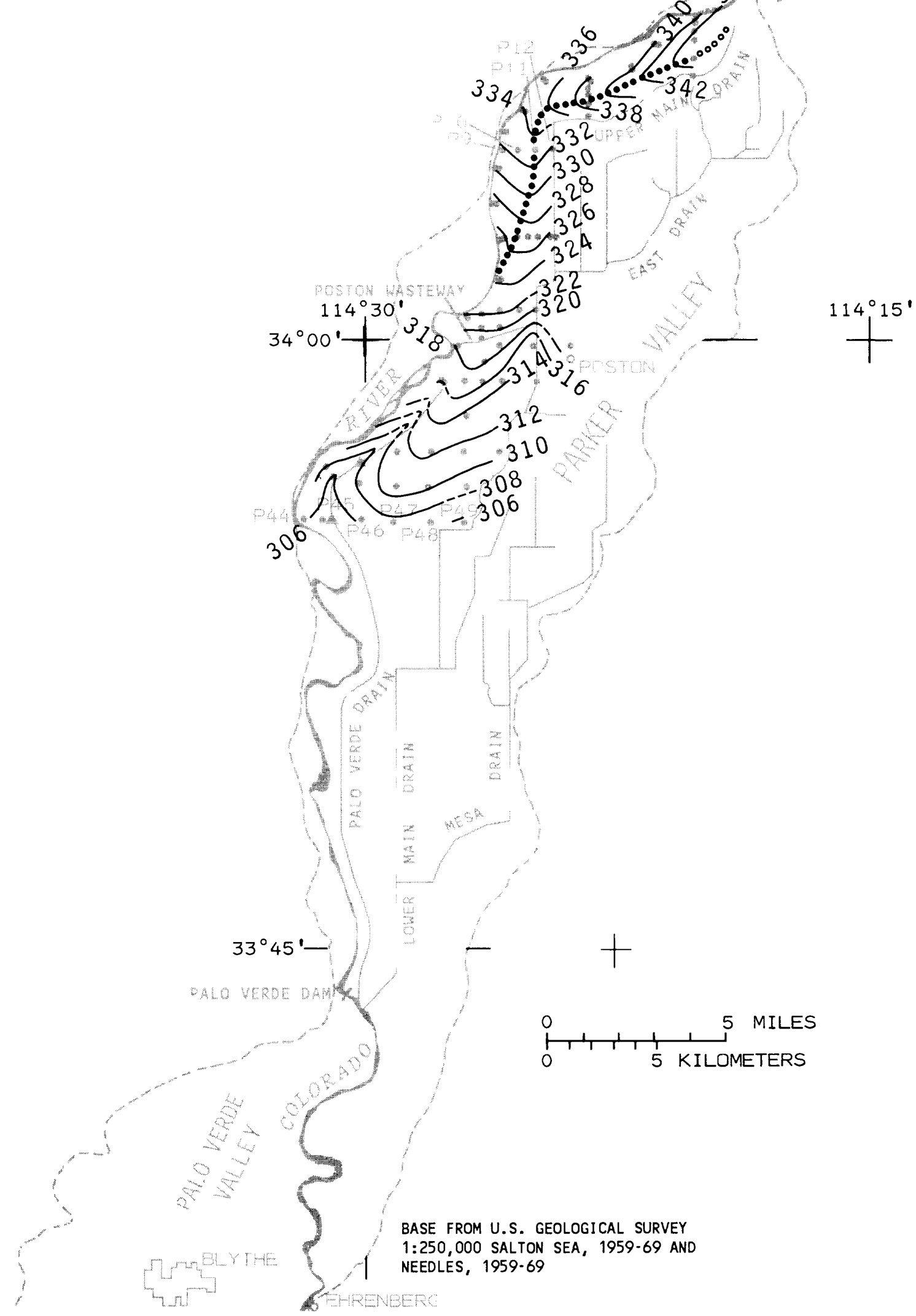

Figure 12.--Average water-table altitude in Parker Valley, Arizona, 1983. 


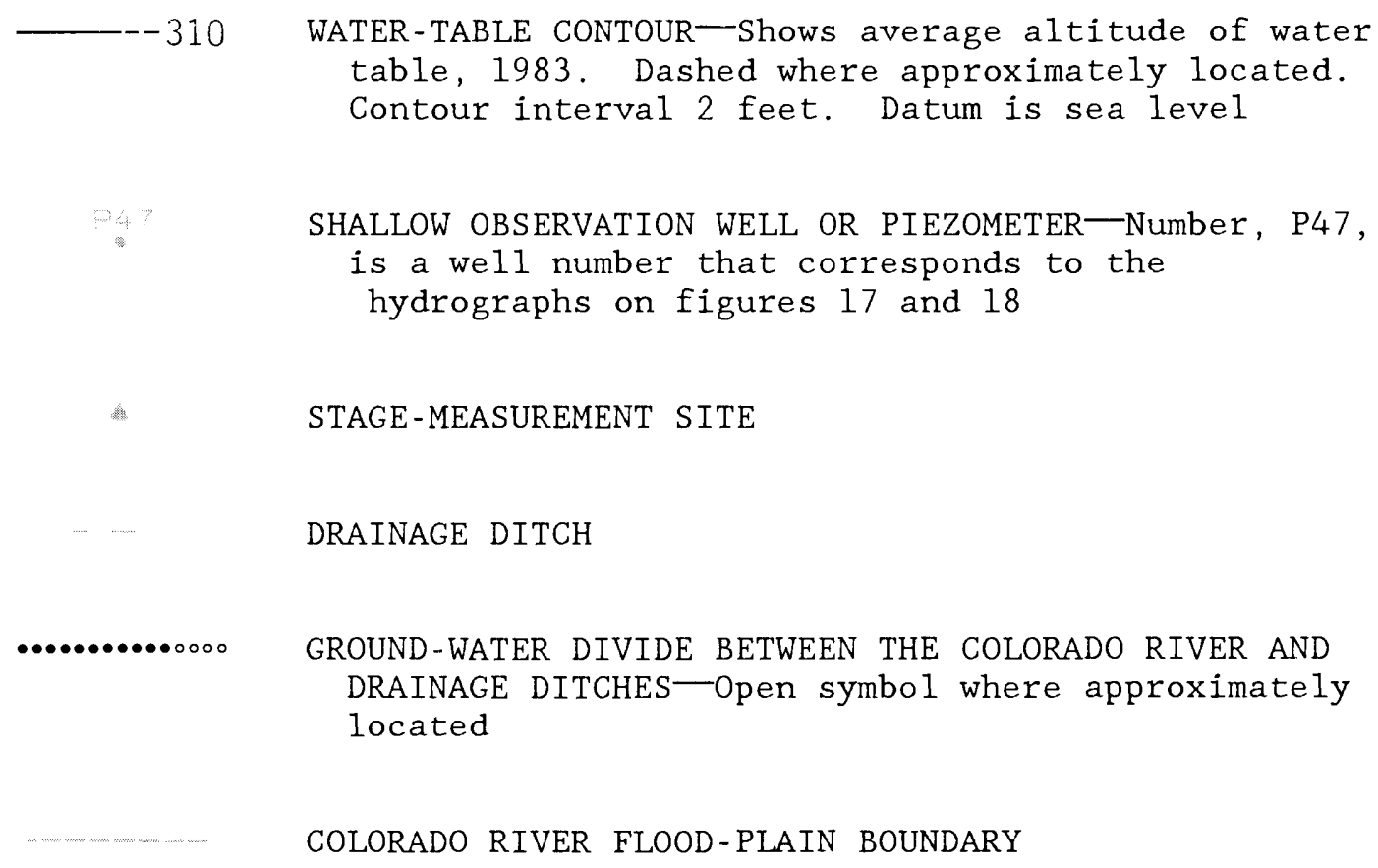




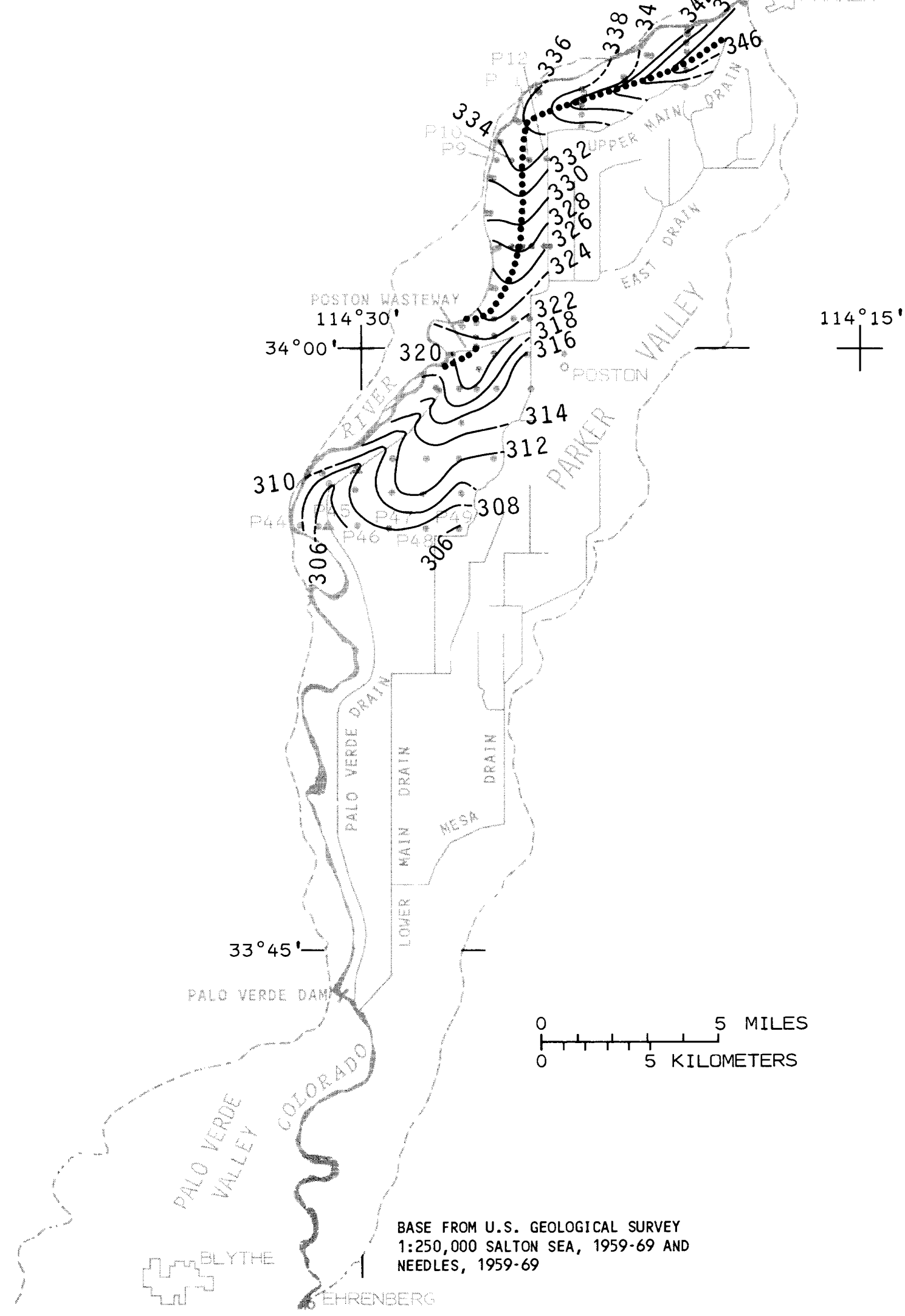

Figure 13.--Average water-table altitude in Parker Valley, Arizona, 1984. 


\footnotetext{
- - - 310 WATER-TABLE CONTOUR-Shows average altitude of water table, 1984. Dashed where approximately located. Contour interval 2 feet. Datum is sea level

SHALLOW OBSERVATION WELL OR PIEZOMETER-Number, P47, is a well number that corresponds to the hydrographs on figures 17 and 18

\&.

STAGE-MEASUREMENT SITE

DRAINAGE DITCH

GROUND-WATER DIVIDE BETWEEN THE COLORADO RIVER AND DRAINAGE DITCHES

COLORADO RIVER FLOOD-PLAIN BOUNDARY
}

Figure 13 


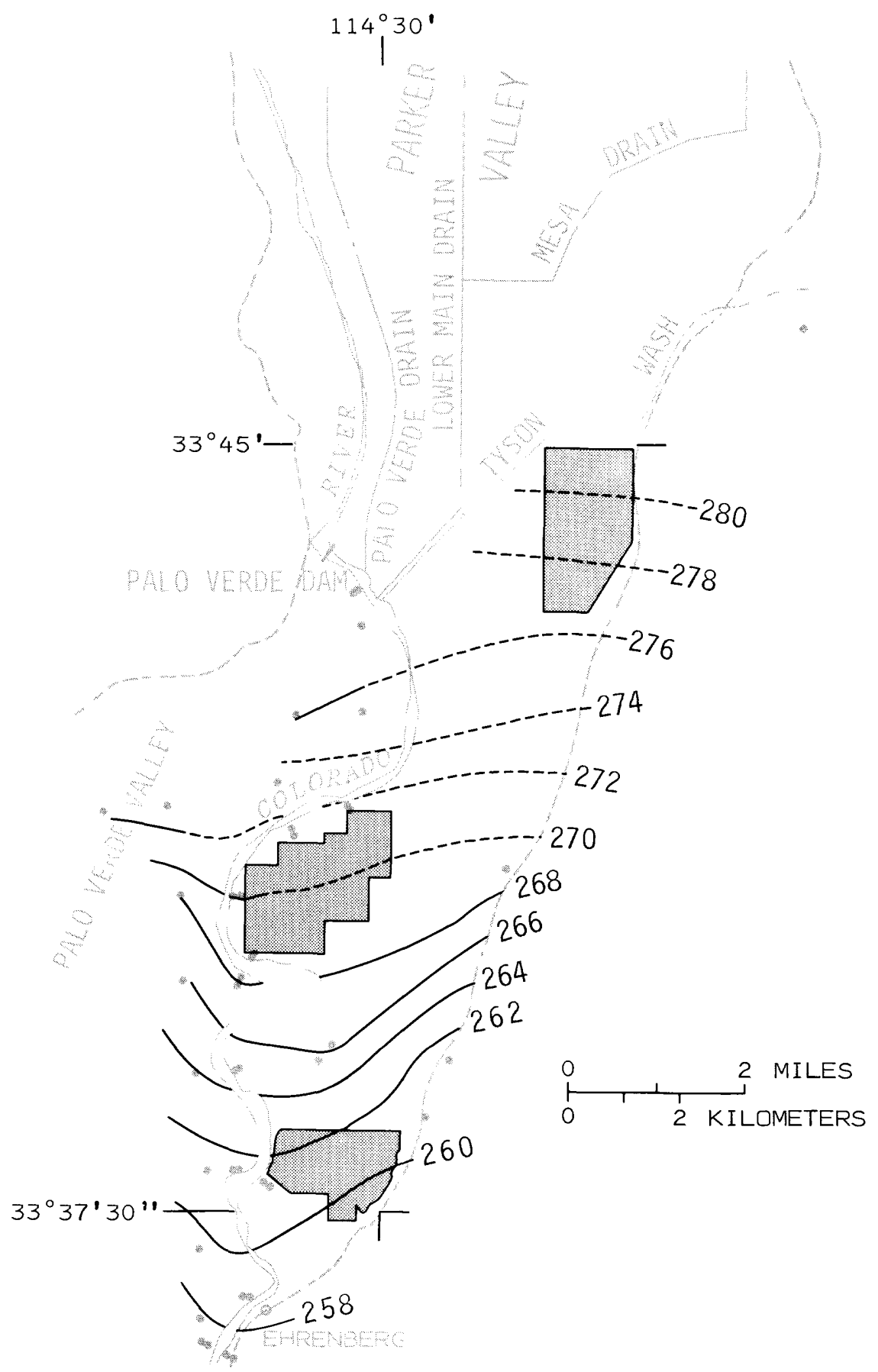

BASE FROM U.S. GEOLOGICAL SURVEY

$1: 250,000$ SALTON SEA, 1959-69

Figure 14.--Water-table altitude in the southern part of Parker Valley, Arizona, November 1984. 
E X P L A N A T I O N

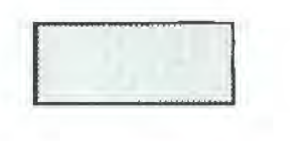

IRRIGATED LAND

$--260$

WATER-TABLE CONTOUR-Shows average altitude of water table, November 1984. Dashed where approximately located. Contour interval 2 feet. Datum is sea leve1

WELL OR PIEZOMETER

COLORADO RIVER FLOOD-PLAIN BOUNDARY

Figure 14 


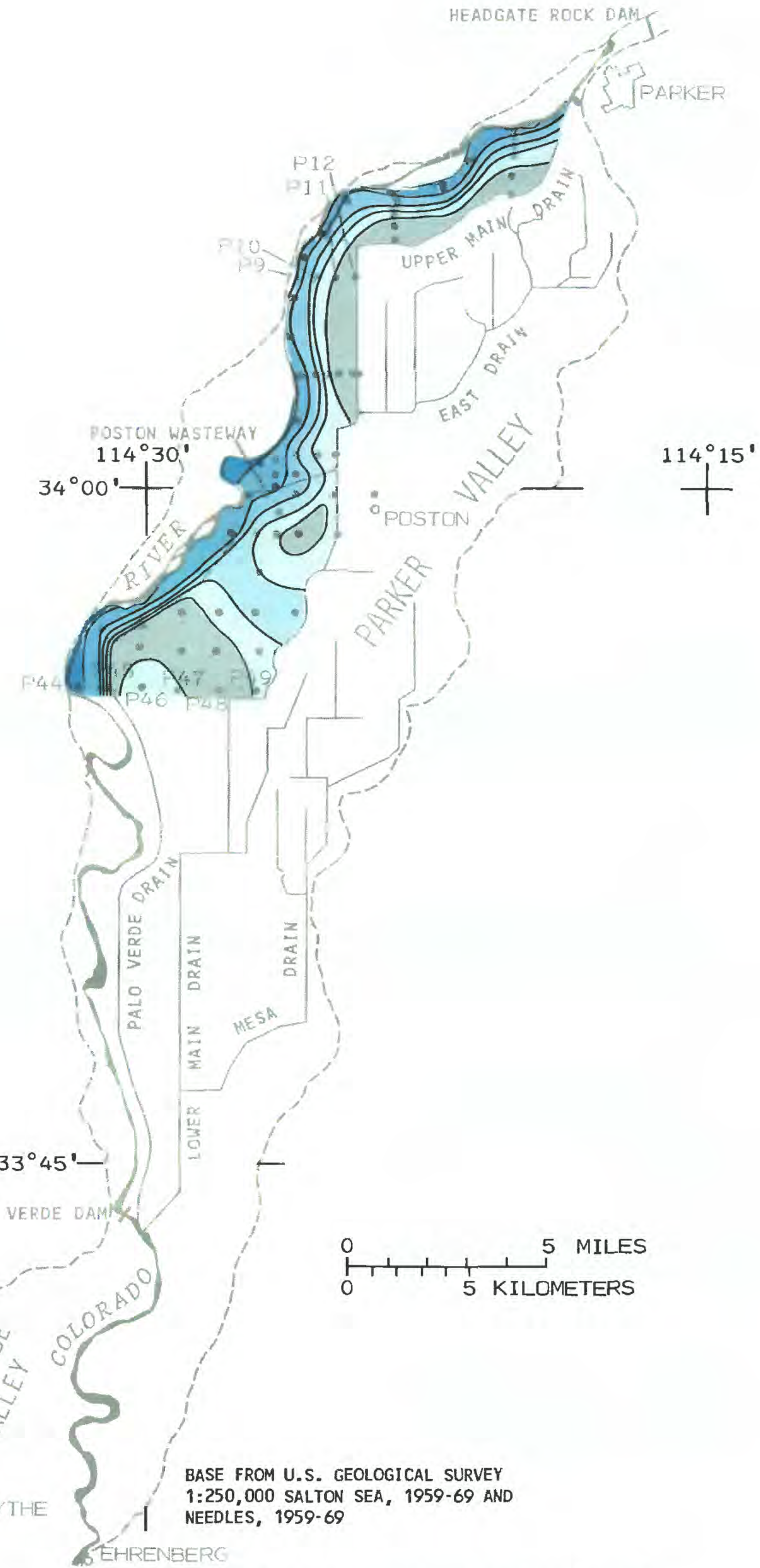

Figure 15.--Change in annual average ground-water levels in Parker Valley, Arizona, 1982-83. 
E X P L A N A T I O N

ANNUAL AVERAGE WATER-LEVEL CHANGE, IN FEET

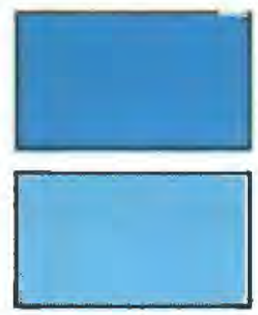

4 to less than 5

3 to less than 4

2 to less than 3

1 to less than 2

0 to less than 1

-1 to less than 0

No data

SHALLOW OBSERVATION WELL OR PIEZOMETER

STAFF GAGE AND CONTINUOUS-RECORD GAGING STATION

DRAINAGE DITCH

COLORADO RIVER FLOOD-PLAIN BOUNDARY

Figure 15 


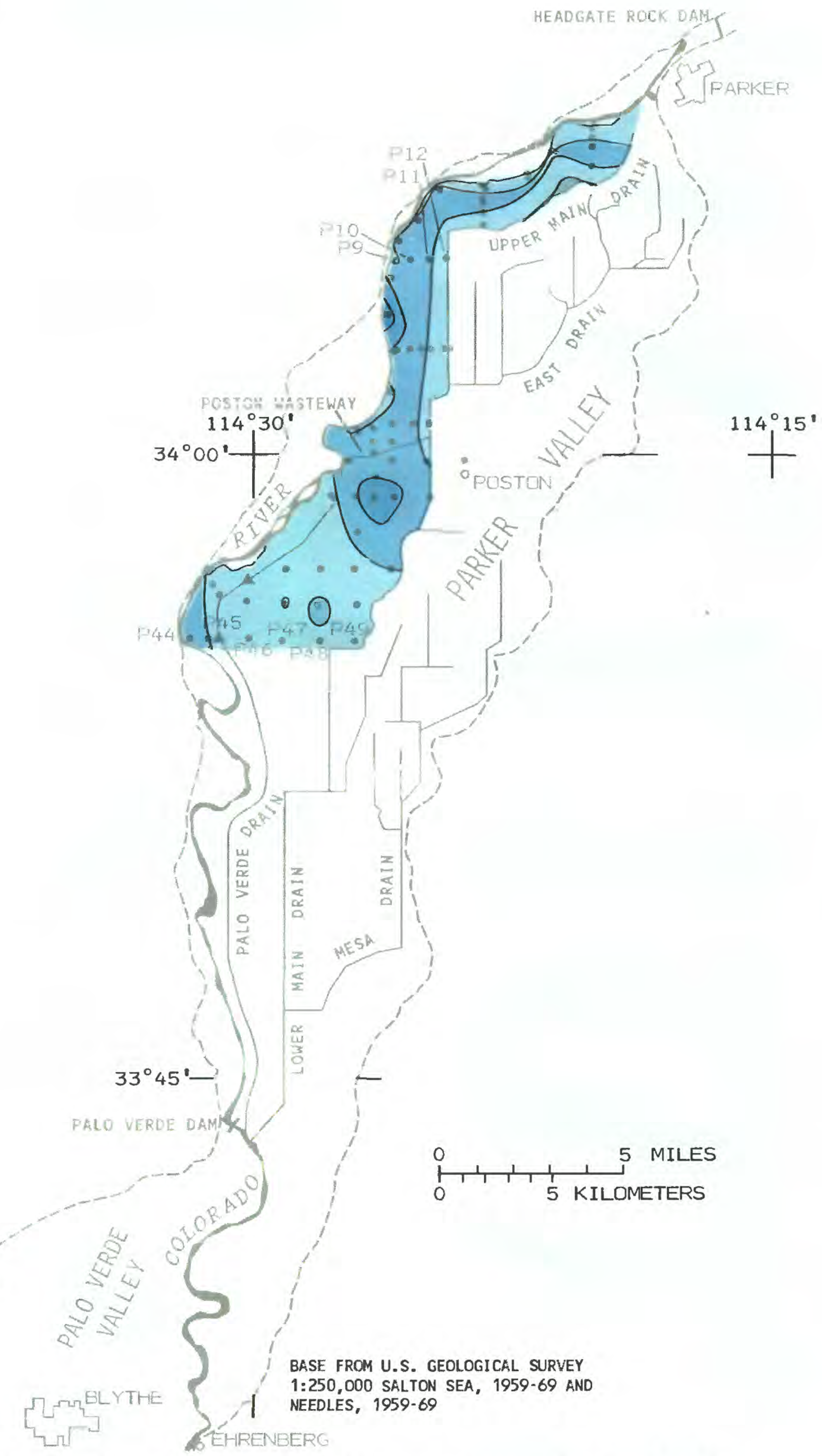

Figure 16.--Change in annual average ground-water levels in Parker. Valley, Arizona, 1983-84. 
E X P L A N A T I O N

ANNUAL AVERAGE WATER-LEVEL CHANGE, IN FEET

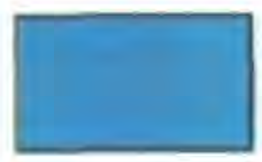

3 to less than 4

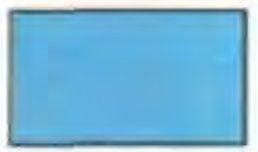

2 to less than 3

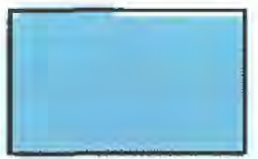

1 to less than 2

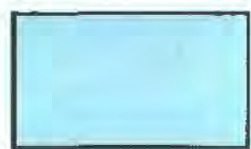

0 to less than 1

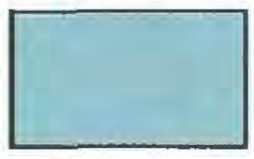

-1 to less than 0

No data

SHALLOW OBSERVATION WELL OR PIEZOMETER

STAFF GAGE AND CONTINUOUS-RECORD GAGING STATION

DRAINAGE DITCH

COLORADO RIVER FLOOD-PLAIN BOUNDARY

Figure 16 
closely with river stage (fig. 7) and flow (fig. 6). Water levels were higher in 1983 and 1984 than in 1981 and 1982. The seasonal changes were present in all years. The water level rose in summer when the irrigation application was high and declined during winter when less irrigation water was applied. We1ls P11 and P12 are 1.0 and $1.5 \mathrm{mi}$ from the river, respectively, and are between the ground-water divide and the westernmost drainage ditch. Water-leve1 changes in we11s P11 and P12 correlate with the seasonal application of irrigation water-high in summer and low in winter. The change in water levels from river stage was smal1, if any, at wel1 P11. We11. P12 showed no effect from the rise in river stage in 1983.

Hydrographs for selected wells south of Poston show similar water-level changes (fig. 18). Wells P44 and P45 are 0.2 and $0.75 \mathrm{mi}$ from the river, respectively, and are between the river and Palo Verde drain. Water-level changes in these wells closely follow changes in river stage. Seasonal. fluctuations in water levels were present during 1981 and 1982 because flow in the river was regulated for downstream water deliveries, whereas during 1983 and 1984 , the seasonal water-level fluctuations were not present because flow in the river was regulated for flood control. Wells $\mathrm{P} 44$ and $\mathrm{P} 45$ are in an area covered by phreatophytes and no irrigation water was applied. Wells P46, P47, and P48 are from 0.8 to $3.75 \mathrm{mi}$ east of Palo Verde drain, and water-level changes correspond with the seasonal application of irrigation water. Overal1, water levels in 1983 and 1984 were not significantly different from those in 1981 and 1982 in this area.

\section{Change in Storage}

Change in ground-water storage was calculated for the area drained by the river (table 7) as the product of changes in ground-water levels, areas of change, and specific yield. Changes in ground-water levels were estimated as the differences between annual average water levels to approximate the net change in ground-water storage. Areas of change were determined by integrating the areas between contours on figures 15 and 16 . Metzger and others (1973, p. 72) measured a specific yield of 0.39 for sediments above the water table in Parker Valley during soil-moisture studies, which was used to calculate change in storage.

Table 7.-- Change in ground-water storage for Parker Valley. Arizona. in acre-feet

\begin{tabular}{lcccc}
\hline & 1981 & 1982 & 1983 & 1984 \\
\hline $\begin{array}{l}\text { Area drained by } \\
\text { drainage ditches }\end{array}$ & $\left({ }^{1}\right)$ & $\left({ }^{1}\right)$ & $\left.{ }^{1}\right)$ & $\left({ }^{1}\right)$ \\
$\begin{array}{l}\text { Area drained by } \\
\text { the river }\end{array}$ & $\left({ }^{1}\right)$ & $\left({ }^{1}\right)$ & 4,600 & 2,600 \\
\hline
\end{tabular}

${ }^{1}$ No water-level data available to calculate change in storage. 


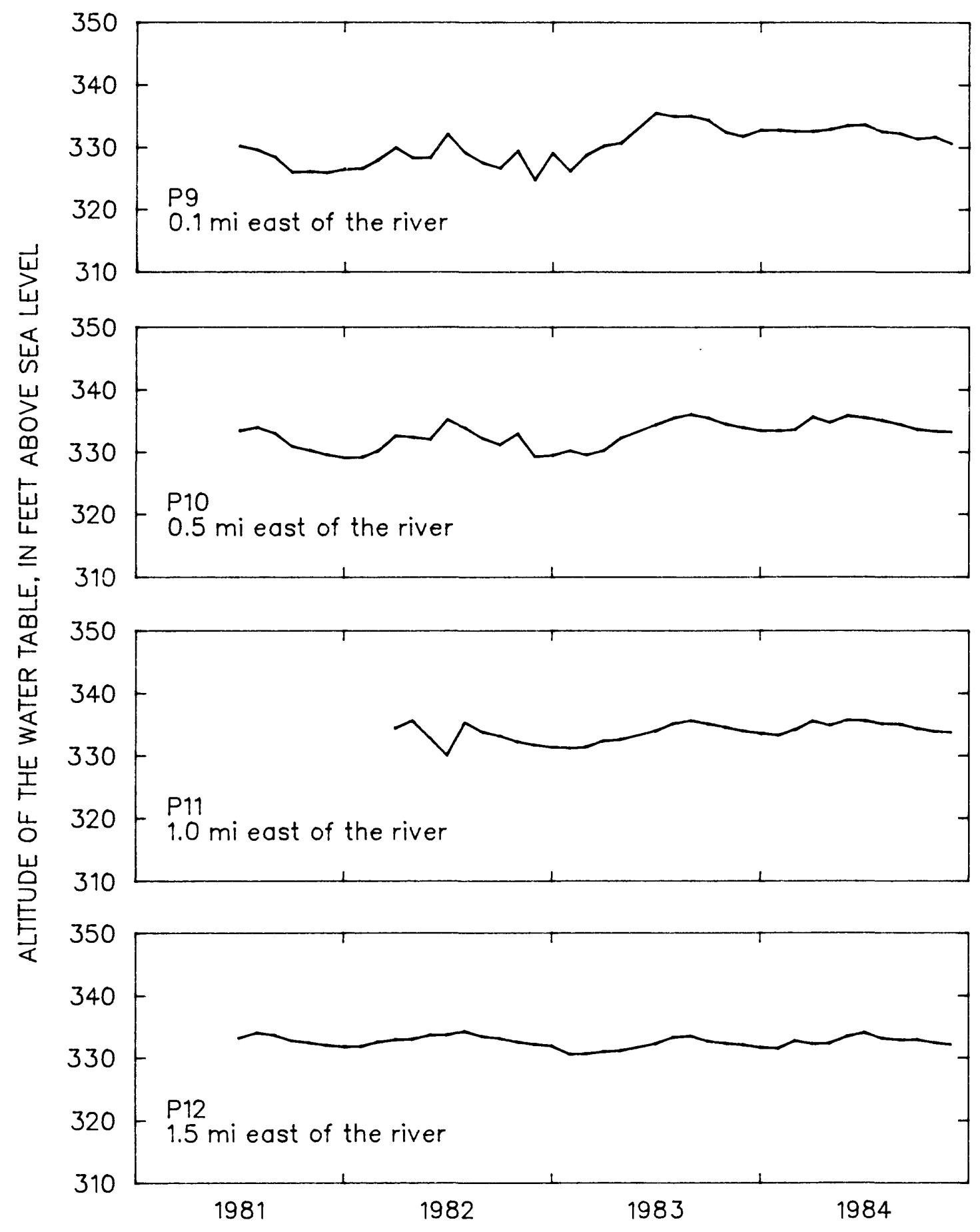

Figure 17.--Water levels in selected wells in northern Parker Valley', Arizona, 1981-84. 


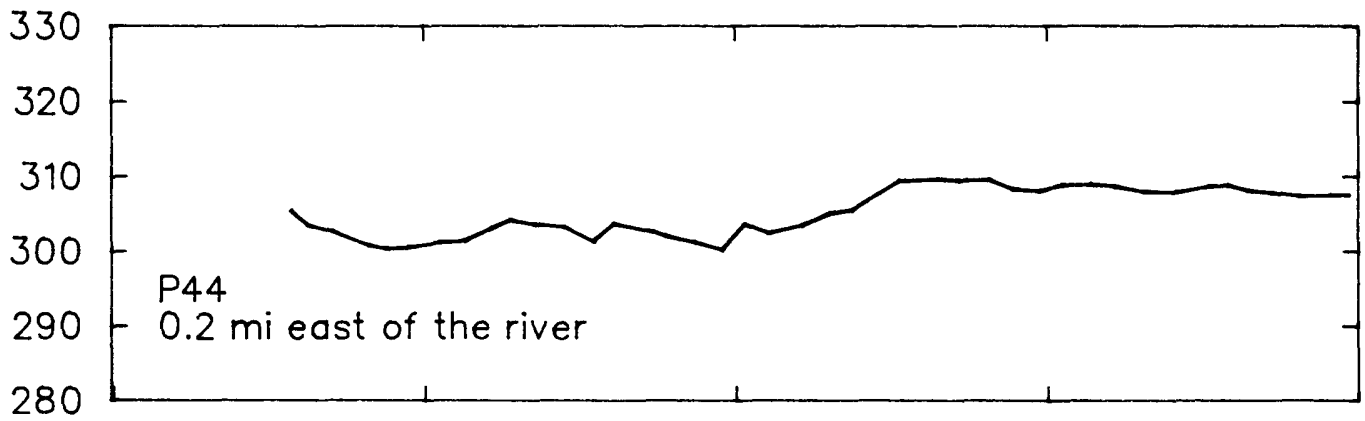

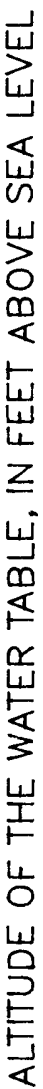
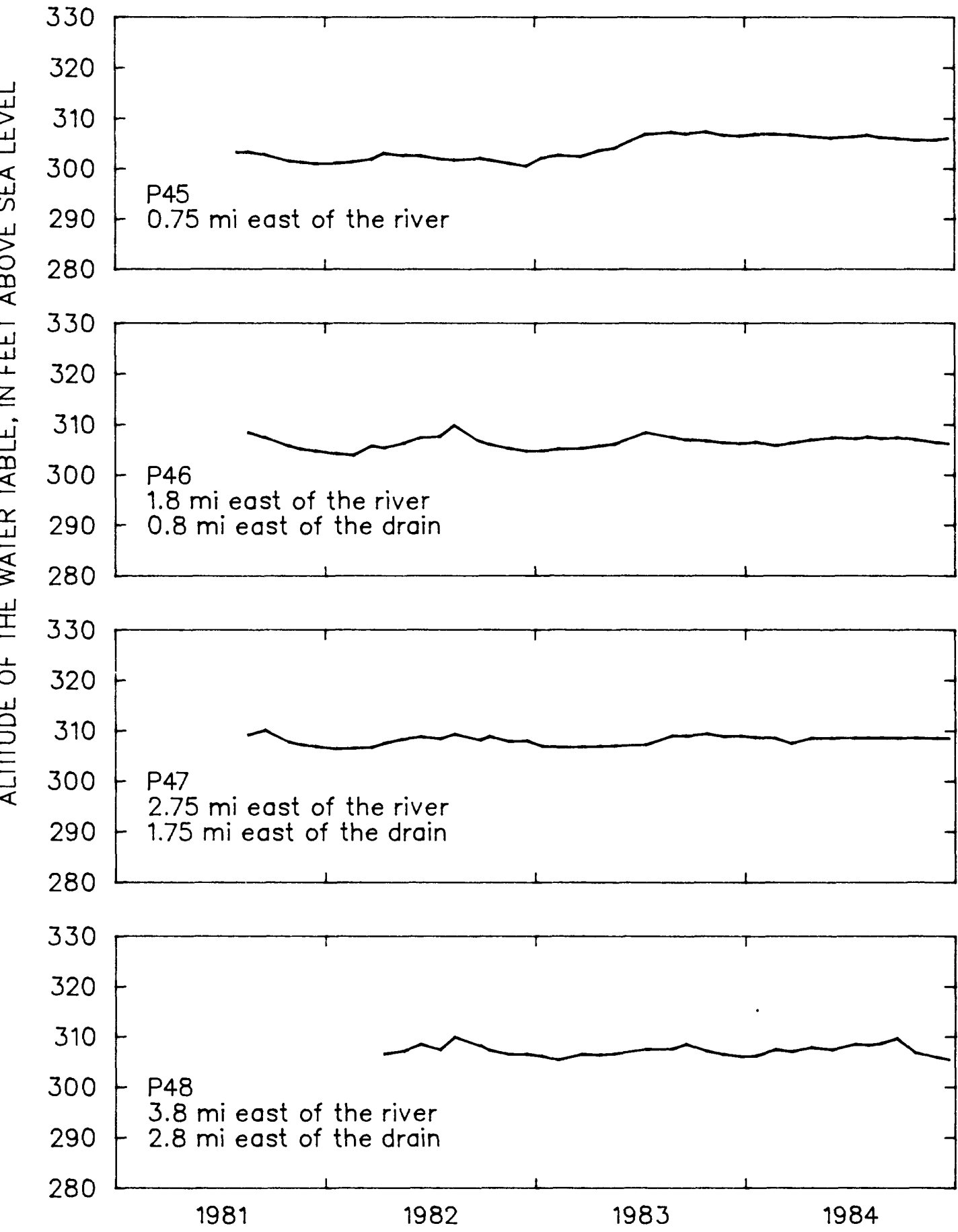

Figure 18.--Water levels in selected wells south of Poston wasteway in Parker Valley, Arizona, 1981-84. 
Change in storage could not be calculated for the area drained by drainage ditches because no observation wells were in the area. In a study to compute consumptive use by vegetation from a water budget in Palo Verde Valley, California, change in storage in the area drained by drainage ditches was such a small percentage of consumptive use by vegetation that it did not affect the computation of that component (Owen-Joyce and Kimsey, 1987). Palo Verde and Parker Valleys share the following characteristics: (1) Most of each valley is agriculturally developed, (2) each has one major point of diversion, and (3) both are drained by an extensive network of drainage ditches. Change in storage, therefore, was assumed to be negligible in the computation of consumptive use by vegetation in Parker Valley.

Estimates of change in storage are small relative to the estimates of consumptive use by vegetation and consumptive use of river water. The accuracy with which change in storage is estimated does not significantly affect either the estimate of consumptive use by vegetation calculated in a water budget or the estimate of consumptive use of Colorado River water calculated as measured diversion minus return flows. The accuracy with which change in storage is estimated has a significant effect on the estimate of ground-water return flow calculated in a water budget because change in storage is of the same magnitude as the estimate of ground-water return flow.

\section{CONSUMPTIVE USE}

Consumptive use by vegetation on the flood plain of Parker Valley is the sum of consumptive use by vegetation for the area north of Tyson Wash, the area south of Tyson Wash, the area on the California side of the river, and the islands in the river (table 8). Consumptive use by vegetation was calculated using a water budget for the area drained by drainage ditches. Consumptive use per unit vegetated area calculated for the area north of Tyson Wash was applied to the other areas. Crop data for the California side of the river was available only for 1984 from digitalimage analysis of Landsat satellite data.

\section{Area Drained By Drainage Ditches}

Consumptive use by vegetation for the area drained by drainage ditches was calculated as the residual in a water budget (equation 1 ) that accounted for inflow as (1) surface-water diversion, (2) effective precipitation, (3) ground-water inflow and tributary runoff from the area east of the flood plain, and (4) seepage from the Colorado River. Outflow occurred as (1) surface-water discharge to the river from the drainage ditches, (2) consumptive use by vegetation, and (3) pumpage (table 9). Diversions and surface-water return flows were measured. Change in storage could not be calculated for the area drained by drainage ditches because change in water-level data was not available and was assumed to be negligible as in Palo Verde Valley (Owen-Joyce and Kimsey, 1987). 
Table 8.--Estimates of consumptive use by vegetation in Parker Valley, Arizona, 1981-84

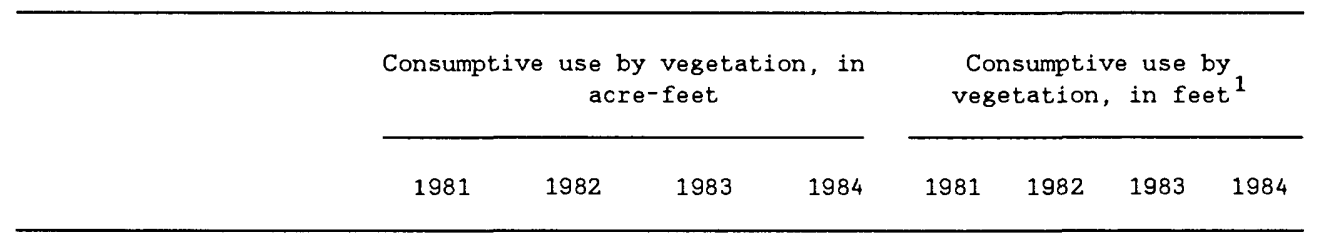

ARIZONA :

North of Tyson Wash:

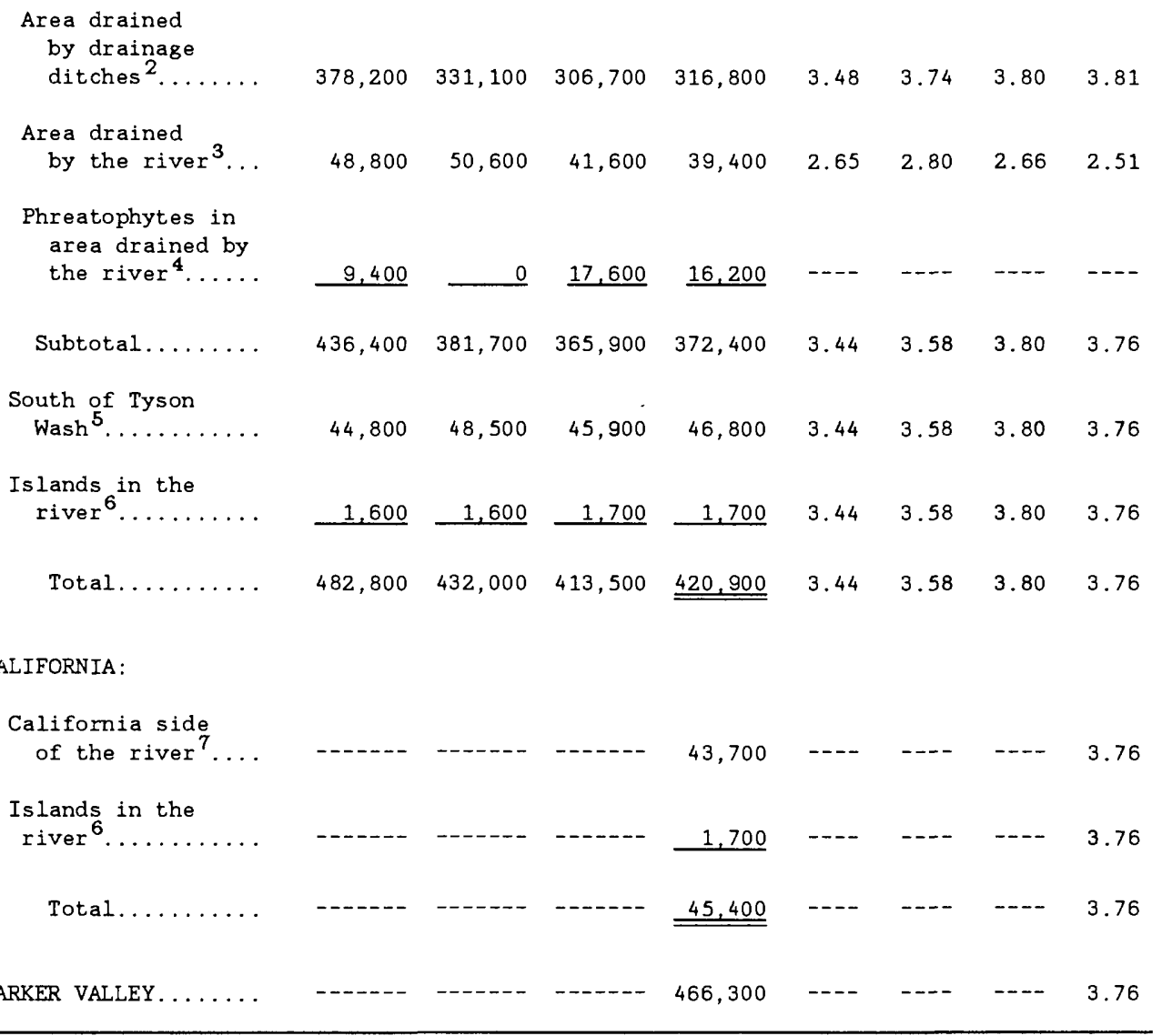

${ }^{1}$ Calculated as consumptive use per unit vegetated area (table 1 ) - the area of crops plus phreatophytes.

${ }^{2}$ Calculated from a water budget (table 9 ).

${ }^{3}$ Consumptive use per unit vegetated area determined for the area drained by drainage ditches adjusted for the unequal distribution of vegetation types in the two drainage areas multiplied by the vegetated area in the area drained by the river (west of the divide, table 1).

Negative ground-water return flow equivalent to induced river seepage consumptively used by phreatophytes (table 17).

From table 15.

${ }^{6}$ Phreatophytes cover 919 acres on islands in the river, which was divided equally between the States for estimating consumptive use by vegetation.

7 From table 16. 
Table 9.--Water budgets for the area drained by drainage ditches in Parker Valley, Arizona, 1981-84, in acre-feet per year

\begin{tabular}{|c|c|c|c|c|}
\hline & 1981 & 1982 & 1983 & 1984 \\
\hline \multicolumn{5}{|l|}{ Inflow: } \\
\hline Surface-water diversion ${ }^{1} \ldots \ldots$ & 545,500 & 483,700 & 475,600 & 514,500 \\
\hline Effective precipitation..... & 20,600 & 27,800 & 21,400 & 14,300 \\
\hline $\begin{array}{l}\text { Ground-water inflow from } \\
\text { the area east of the } \\
\text { flood plain }{ }^{2} \ldots \ldots \ldots \ldots \ldots\end{array}$ & 4,950 & 4,950 & 4,950 & 4,950 \\
\hline Tributary runoff ${ }^{3}$. & 7,400 & 7,400 & 7,400 & 7,400 \\
\hline 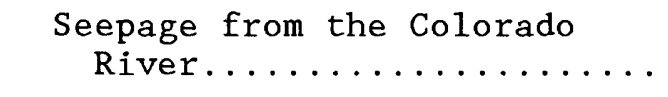 & 24,600 & 23,500 & 31.200 & 47,400 \\
\hline Total (rounded)..... & 603,100 & 547,400 & 540,600 & 588,600 \\
\hline \multicolumn{5}{|l|}{ Outflow: } \\
\hline $\begin{array}{l}\text { Surface-water discharge to } \\
\text { Colorado River from } \\
\text { drainage ditches }{ }^{4} \ldots \ldots \ldots\end{array}$ & 224,800 & 216,000 & 233,900 & 271,800 \\
\hline $\begin{array}{l}\text { Consumptive use by } \\
\quad \text { vegetation } 5 \ldots \ldots \ldots \ldots\end{array}$ & 378,200 & 331,100 & 306,700 & 316,800 \\
\hline Pumpage........... & 111 & 264 & 4 & 0 \\
\hline Total (rounded). & 603,100 & 547,400 & 540,600 & 588,600 \\
\hline Change in storage: & $\left({ }^{6}\right)$ & $\left({ }^{6}\right)$ & $\left({ }^{6}\right)$ & $\left({ }^{6}\right)$ \\
\hline
\end{tabular}

${ }^{1}$ See table 10.

${ }^{2}$ Metzger and others (1973, p. 51-52).

${ }^{3}$ Metzger and others (1973, p. 61).

${ }^{4}$ See table 3 .

${ }^{5}$ Consumptive use by vegetation calculated as inflow minus other outflows minus change in storage.

${ }^{6}$ Negligible.

The surface-water diversion to the area drained by drainage ditches was calculated by determining the quantity of water diverted from the river that (1) was applied to fields, (2) seeped from the canals, (3) spilled to the river, (4) was wasted to drainage ditches, and (5) evaporated from canals and by summing the proportion of each component that 
occurred in the drainage area (table 10). The applied water was apportioned between the two drainage areas using the percentages determined from irrigation requirements (table 1) -the volume of water per unit area required to grow each crop-in order to account for the effect of areal distribution of crops on the areal distribution of applied water (OwenJoyce, 1984, p. 27). Canal seepage and evaporation were apportioned by canal length (Owen-Joyce, 1984, p. 29). The quantity of water spilled to the river was estimated by the U.S. Bureau of Indian Affairs (Tom Claw, written commun., 1985). The surface-water diversion to the area drained by drainage ditches (east of the divide) may be expressed as:

$$
S W D_{d}=S W D\left(\frac{I R Q_{e}}{I R Q_{e}+I R Q_{w}}\right)+S_{c}\left(\frac{C l e}{C l e+C 1 w}\right)+R w+E_{c}\left(\frac{C l e}{C l e+C 1 w}\right)
$$

where

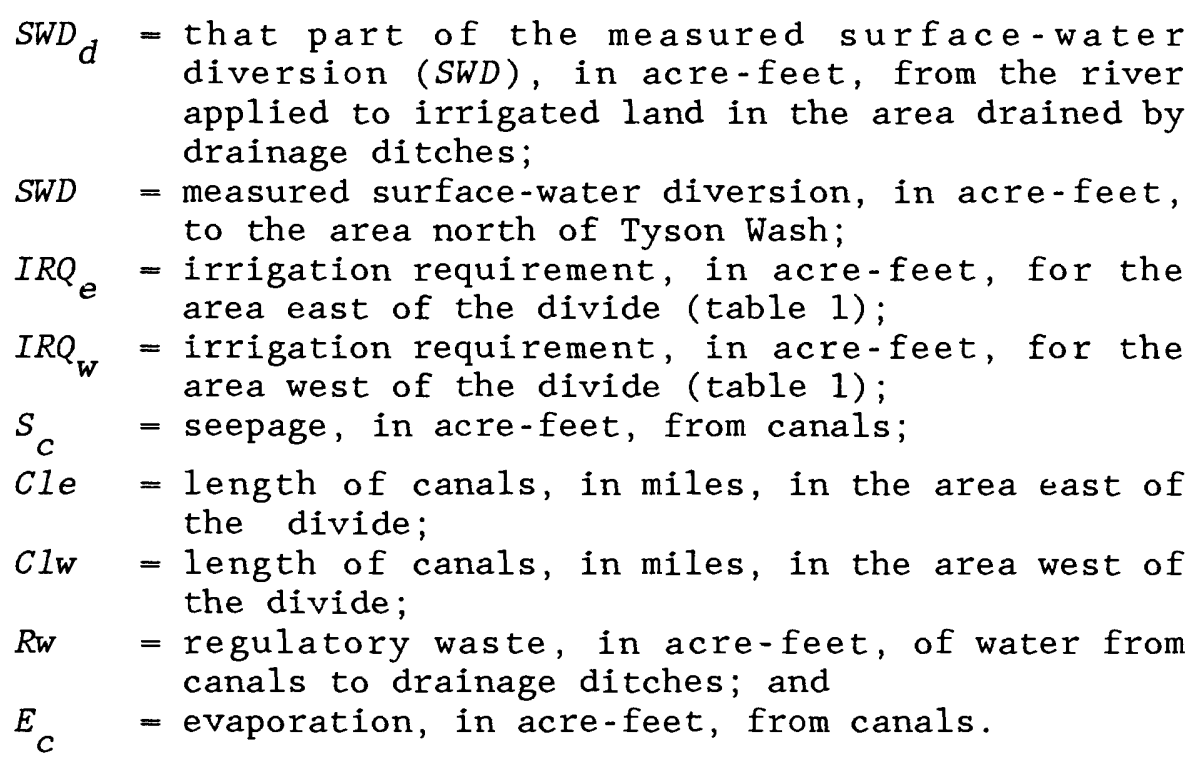

In a study by Boyle Engineering Corp. (1976, p. III-52), seepage and evaporation from canals were estimated to be 92,639 acre-ft/yr and 3,940 acre-ft/yr, respectively. Canal seepage and evaporation was about 15 percent ( 14 percent for seepage and 1 percent for evaporation) of the diversion during the Boyle study, which was the percentage used by the U.S. Bureau of Indian Affairs to estimate canal seepage and evaporation until some canals were lined. After the canals were lined, the U.S. Bureau of Indian Affairs reduced the estimate of canal seepage and evaporation to 12 percent (Tom Claw, oral commun., 1986). For the purpose of this study, the Boyle estimate of evaporation ( 1 percent) is used because lining the canal would not affect evaporation. The 3-percent reduction was applied to the 14-percent estimate of canal seepage, which reduced canal seepage to 11 percent. Canal seepage was then estimated as 11 percent of the diversion for 1981-84 (table 10). 
Table 10.--Estimates of surface-water diversions to irrigated land north of Tyson Wash in Parker Valley, Arizona, 1981-84, in acre-feet per year

\begin{tabular}{|c|c|c|c|c|}
\hline & 1981 & 1982 & 1983 & 1984 \\
\hline \multicolumn{5}{|l|}{ Diversion to Parker Valley: } \\
\hline $\begin{array}{l}\text { Surface-water diversion } \\
\text { at Headgate Rock Dam }{ }^{1} \text {. }\end{array}$ & 608,100 & 566,300 & 539,500 & 584,800 \\
\hline $\begin{array}{l}\text { Diversion from pumps } \\
\text { in the river }{ }^{2} \ldots \ldots \ldots \ldots \ldots\end{array}$ & 1,542 & 0 & 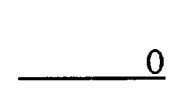 & $\longrightarrow$ \\
\hline $\begin{array}{l}\text { Subtotal of diversions } \\
\text { (rounded) } \ldots \ldots \ldots \ldots\end{array}$ & $\underline{\underline{609}, 600}$ & $\underline{\underline{566,300}}$ & $\underline{\underline{539,500}}$ & $\underline{\underline{584,800}}$ \\
\hline $\begin{array}{l}\text { Canal seepage between } \\
\text { dam and valley }{ }^{3} \ldots \ldots\end{array}$ & 2,365 & 2,365 & 2,365 & 2,365 \\
\hline $\begin{array}{l}\text { Canal seepage in valley } \\
(\text { rounded })^{4} \ldots \ldots \ldots \ldots\end{array}$ & 67,100 & 62,300 & 59,300 & 64,300 \\
\hline Spills to river ${ }^{5} \ldots \ldots \ldots \ldots$ & 21,900 & 28,600 & 32,800 & 40,600 \\
\hline $\begin{array}{l}\text { Regulatory waste to } \\
\text { drainage ditches } \\
6\end{array}$ & 77,129 & 91,324 & 119,761 & 85,608 \\
\hline Evaporation from canals ${ }^{7}$ & 3,940 & 3,940 & 3,940 & 3,940 \\
\hline $\begin{array}{l}\text { Deliveries to area south } \\
\text { of Tyson Wash }{ }^{8} \ldots \ldots \ldots\end{array}$ & 4.863 & 4,940 & 4.215 & 4,204 \\
\hline $\begin{array}{l}\text { Subtotal of water loss } \\
\quad \text { (rounded) } \ldots \ldots \ldots \ldots \ldots \ldots\end{array}$ & $\underline{\underline{177,300}}$ & $\underline{\underline{193,500}}$ & $\underline{\underline{222}, 400}$ & $\underline{\underline{201,000}}$ \\
\hline $\begin{array}{l}\text { Net water applied to } \\
\text { irrigated land.... }\end{array}$ & 432,300 & 372,800 & 317,100 & 383,800 \\
\hline \multicolumn{5}{|l|}{$\begin{array}{l}\text { Diversion to area } \\
\text { west of divide: }\end{array}$} \\
\hline $\begin{array}{l}\text { Surface water applied to } \\
\text { irrigated land........... }\end{array}$ & 28,532 & 39,890 & 19,343 & 19,190 \\
\hline $\begin{array}{l}\text { Regulatory waste to } \\
\text { drainage ditches.......... }\end{array}$ & 0 & 0 & 0 & 0 \\
\hline 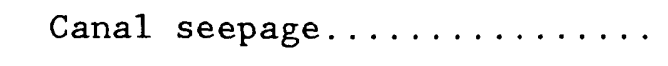 & 6,106 & 6,355 & 4,863 & 3,729 \\
\hline Evaporation from canals..... & 359 & 402 & 323 & 229 \\
\hline Total diversion (rounded).. & 35,000 & 46,600 & 24,500 & 23,100 \\
\hline
\end{tabular}


Table 10.--Estimates of surface-water diversions to irrigated land north of Tyson Wash in Parker Valley, Arizona, 1981-84, in acre-feet per year--Continued

\begin{tabular}{|c|c|c|c|c|}
\hline & 1981 & 1982 & 1983 & 1984 \\
\hline \multicolumn{5}{|l|}{$\begin{array}{l}\text { Diversion to area } \\
\text { east of divide: }\end{array}$} \\
\hline $\begin{array}{l}\text { Surface water applied to } \\
\quad \text { irrigated land.......... }\end{array}$ & 403,768 & 332,910 & 297,757 & 364,610 \\
\hline $\begin{array}{l}\text { Regulatory waste to } \\
\text { drainage ditches.......... }\end{array}$ & 77,129 & 91,324 & 119,761 & 85,608 \\
\hline Canal seepage... & 60,994 & 55,945 & 54,437 & 60,571 \\
\hline Evaporation from canals..... & 3,581 & 3.538 & 3,617 & 3,711 \\
\hline Total diversion (rounded).. & 545,500 & 483,700 & 475,600 & 514,500 \\
\hline
\end{tabular}

${ }^{1}$ Gaged by the U.S. Geological Survey, Colorado River Indian Reservation Main Canal near Parker.

${ }^{2}$ About $1 \mathrm{mi}$ upstream from Palo Verde Dam.

${ }^{3}$ Estimated by Boyle Engineering Corp. (1976, p. III-18).

4 Estimated as 11 percent of the total diversion to Parker Valley.

${ }^{5}$ Measured and computed by the U.S. Geological Survey (see table 3).

${ }^{6}$ Estimated quantity reported by the U.S. Bureau of Indian Affairs (Tom Claw, written commun., 1986).

${ }^{7}$ Estimated by Boyle Engineering Corp. (1976, p. III-52).

${ }^{8}$ Reported by U.S. Bureau of Indian Affairs (C.B. Kresge, written commun., 1987).

Ground-water inflow and tributary runoff from the area east of the flood plain and ground-water pumpage were estimated in previous studies. Ground-water inflow was estimated to total 4,950 acre-ft/yr-1, 200 acre$\mathrm{ft} / \mathrm{yr}$ from Bouse Wash, 3,400 acre-ft/yr across the northeast boundary, and 350 acre-ft/yr from Tyson Wash (Metzger and others, 1973, p. 51-52). Tributary runoff, some of which recharges the aquifer and some of which is consumed by phreatophytes, was estimated to total 7,400 acre-ft/yr-4,800 acre-ft/yr from Bouse Wash and 2,600 acre-ft/yr from Tyson Wash (Metzger and others, 1973, p. 61). Ground-water pumpage consumptively used for domestic and municipal purposes at Poston was estimated to be equivalent to the pumpage from four pumps in the river. Little, if any, of the water pumped returned to the aquifer or river because sewage returns are evaporated from lined lagoons. Pumpage was 111 acre-ft in 1981 (U.S. Bureau of Reclamation, 1982, p. 7), 264 acre-ft in 1982 (U.S. Bureau of Reclamation, 1984, p. 7), 4 acre-ft in 1983 (U.S. Bureau of Reclamation, 1985 , p. 7), and 0 acre-ft in 1984 (U.S. Bureau of Reclamation, 1986, p. 7). Pumpage began to decrease in 1983 as the source of water for Poston was transferred to wells on the mesa, which supply water to Parker. 
Total river seepage equals the quantity of river seepage in Palo Verde drain (table 4) and the quantity consumed by phreatophytes between the river and drain. About 6,600 acres of phreatophytes, which were mapped from aerial photographs and digitized, consumed about 22,400 acre-ft of ground water that originated as river seepage. Vegetation-type maps show that beiween the river and Palo Verde drain the phreatophytes are a mixture of saltcedar, mesquite, and arrowweed (Anderson and Ohmart, 1976), which is the mixture characteristic of the reach below Palo Verde Dam. Along the reach of the river below Palo Verde Dam, the annual consumptive use of water by phreatophytes is $3.4 \mathrm{ft}$ (Boyle Engineering Corp., 1976, p. II-7).

\section{Area Drained by the River}

Consumptive use by vegetation (table 8) for the area drained by the river may be expressed as:

$$
C U v_{r}=C U v_{d}\left(\frac{A v_{r}}{A v_{d}}\right)\left(\frac{E T_{r}}{E T_{d}}\right),
$$

where

$$
\begin{aligned}
C U v_{r}= & \text { estimated consumptive use by vegetation, in acre-feet, in } \\
& \text { the area drained by the river; } \\
C U v_{d}= & \text { estimated consumptive use by vegetation, in acre-feet, in } \\
& \text { the area drained by drainage ditches (see equation } 1 \text { ); } \\
A V_{r}= & \text { the area of vegetation, in acres, in the area drained by } \\
& \text { the river (west of the divide, table } 1 \text { ); } \\
A v_{d}= & \text { the area of vegetation, in acres, in the area drained by } \\
& \text { drainage ditches (east of the divide, table } 1 \text { ); } \\
E T_{r}= & \text { evapotranspiration, in acre-feet, in the area drained by } \\
& \text { the river (west of the divide, table } 1 \text { ); } \\
E T_{d}= & \text { evapotranspiration, in acre-feet, in the area drained by } \\
& \text { drainage ditches (east of the divide, table } 1 \text { ). }
\end{aligned}
$$

An analysis of evapotranspiration by vegetation types indicated that evapotranspiration per unit vegetated area was higher in the area drained by drainage ditches than that in the area drained by the river (table 11). The percent difference in evapotranspiration between the two drainage areas was used to adjust consumptive use by vegetation for the unequal distribution of vegetation types. Alfalfa and cotton covered a greater percentage of the cultivated area, which caused the higher value of evapotranspiration per unit vegetated area in the area drained by the drainage ditches. Both crops transpire more water per year than the phreatophytes. In the area drained by the river, there are more phreatophytes per unit area. 
Table 11.--Evapotranspiration per unit vegetated area in Parker Valley. Arizona, 1981-84

\begin{tabular}{llll}
\hline & \multicolumn{2}{c}{ Evapotranspiration, in feet } & \\
\cline { 2 - 4 } Year & $\begin{array}{l}\text { Area drained by } \\
\text { drainage ditches }\end{array}$ & $\begin{array}{l}\text { Area drained } \\
\text { by the river }\end{array}$ & $\begin{array}{c}\text { Percent } \\
\text { difference }\end{array}$ \\
\hline & 3.89 & 2.94 & -24 \\
1981 & 3.81 & 2.87 & -25 \\
1982 & 4.01 & 2.82 & -30 \\
1984 & 3.94 & 2.62 & -34 \\
\hline
\end{tabular}

${ }^{1}$ Evapotranspiration per unit vegetated area (table 1 ).

Area North of Tyson Wash

Consumptive use by vegetation for the area north of Tyson Wash is the sum of consumptive use by vegetation for the area drained by drainage ditches and the area drained by the river (table 8). Estimates of consumptive use per unit vegetated area for the area north of Tyson Wash ranged from 3.5 to 5.6 percent less than consumptive use per unit vegetated area for the area drained by drainage ditches (table 8 ). This difference was the result of the 2.0-foot evapotranspiration used in the analysis for the phreatophyte mixture north of $\mathrm{Pal}$ lo Verde Dam because phreatophytes covered 70 to 80 percent of the area drained by the river. The water-budget analysis was run with an evapotranspiration of $3.4 \mathrm{ft}$ for phreatophytes, which is characteristic of the area south of Palo Verde Dam (Boyle Engineering Corp., 1976, p. II-7). The difference between the two estimates of consumptive use per unit vegetated area was from 0.7 to 1.7 percent when the higher evapotranspiration value was used. The difference between the two analyses indicates that the 2.0-foot evapotranspiration was too low for Parker Valley or that different water-use rates should be used in the two drainage areas because of different phreatophyte mixtures.

A sensitivity analysis was done to determine the change in computed consumptive use by vegetation north of Tyson Wash for a specified change of a primary variable. Sensitivity values for consumptive use by vegetation (table 12) indicate that consumptive use by vegetation is most sensitive to the diversion at Headgate Rock Dam and discharge from drainage ditches to the river from the area east of the divide; both variables are measured quantities. For a valley drained by a network of drainage ditches with one major point of diversion, the estimate of consumptive use by vegetation depends mostly on the accuracy with which the diversion and surface-water return flows are measured.

Consumptive use by vegetation consistently decreased from 1381 through 1983, with a slight increase from 1983 to 1984 (fig. 19). Consumptive use by vegetation decreased with decreases in cropped area and the quantity of water diverted from the river between 1981 and 1983 


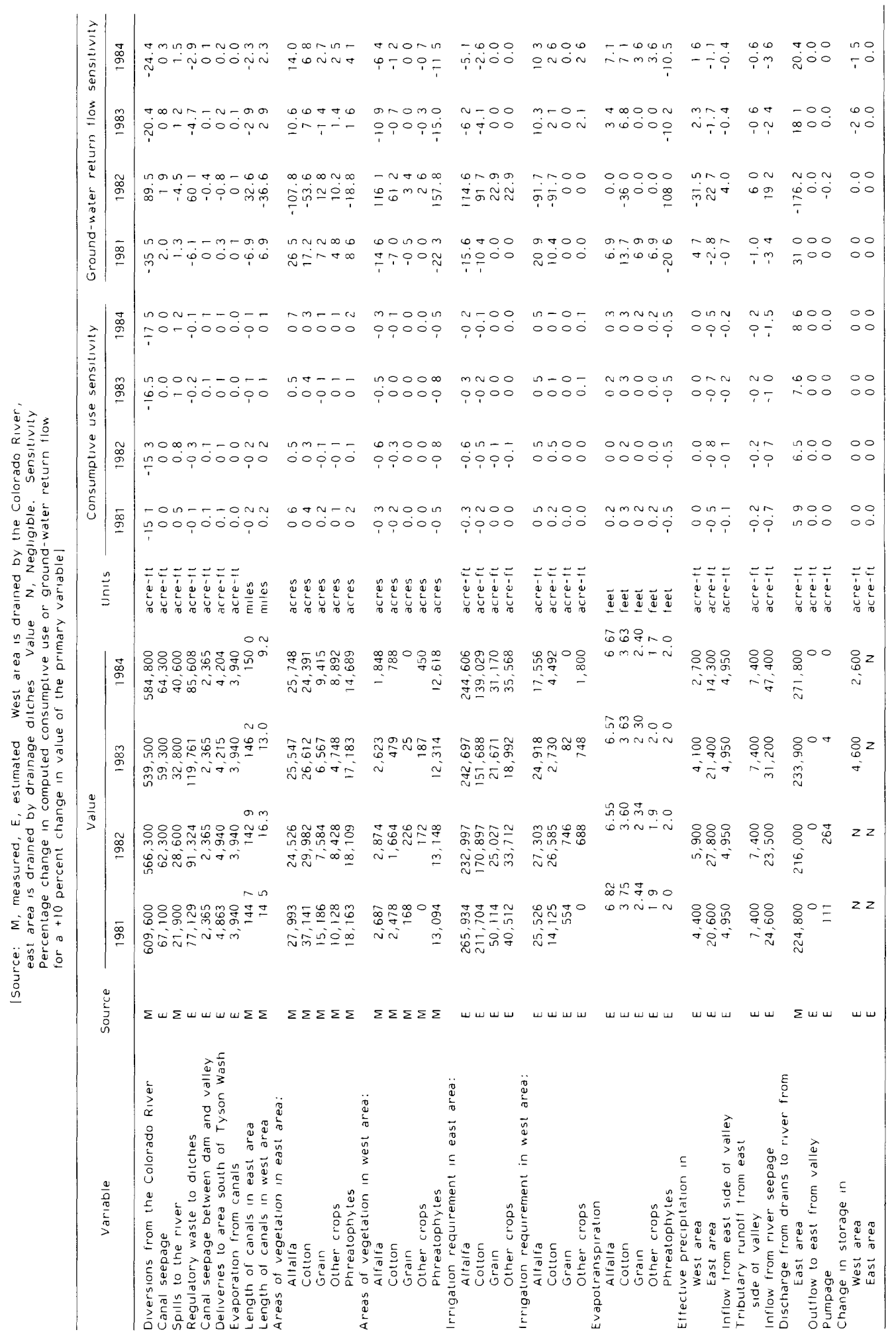


(fig. 3). From 1983 to 1984, the cropped area increased by about half of the cropped area lost from 1981 to 1982. The quantity of water diverted in 1984 exceeded the diversion in 1982. Consumptive use by vegetation increased slightly from 1983 to 1984. A comparison of the estimates of consumptive use by vegetation (table 8 ) and evapotranspiration (table 1) for Parker Valley shows that both components follow the same year-to-year trend from 1981 to 1984 (fig. 19). Consumptive use by vegetation is not equal to evapotranspiration but, evapotranspiration is a major part of consumptive use by vegetation; however, during 3 of the 4 years, estimates of evapotranspiration were higher than estimates of consumptive use by vegetation-9 percent higher in 1981, 2 percent higher in 1982, 0.5 percent higher in 1983, and 1 percent lower in 1984.

Year-to-year variations in consumptive use per unit vegetated area (fig. 20) do not follow the same trend as year-to-year variations in consumptive use by vegetation (fig. 19). Consumptive use per unit vegetated area increased from 1981 to 1983 and then decreased slightly in 1984. In a comparison of estimates of consumptive use and evapotranspiration per unit vegetated area, both components vary little from year to year but again consumptive use is less than evapotranspiration (fig. 20). The percent differences in the two components are the same for the total quantity or the quantity per unit vegetated area.

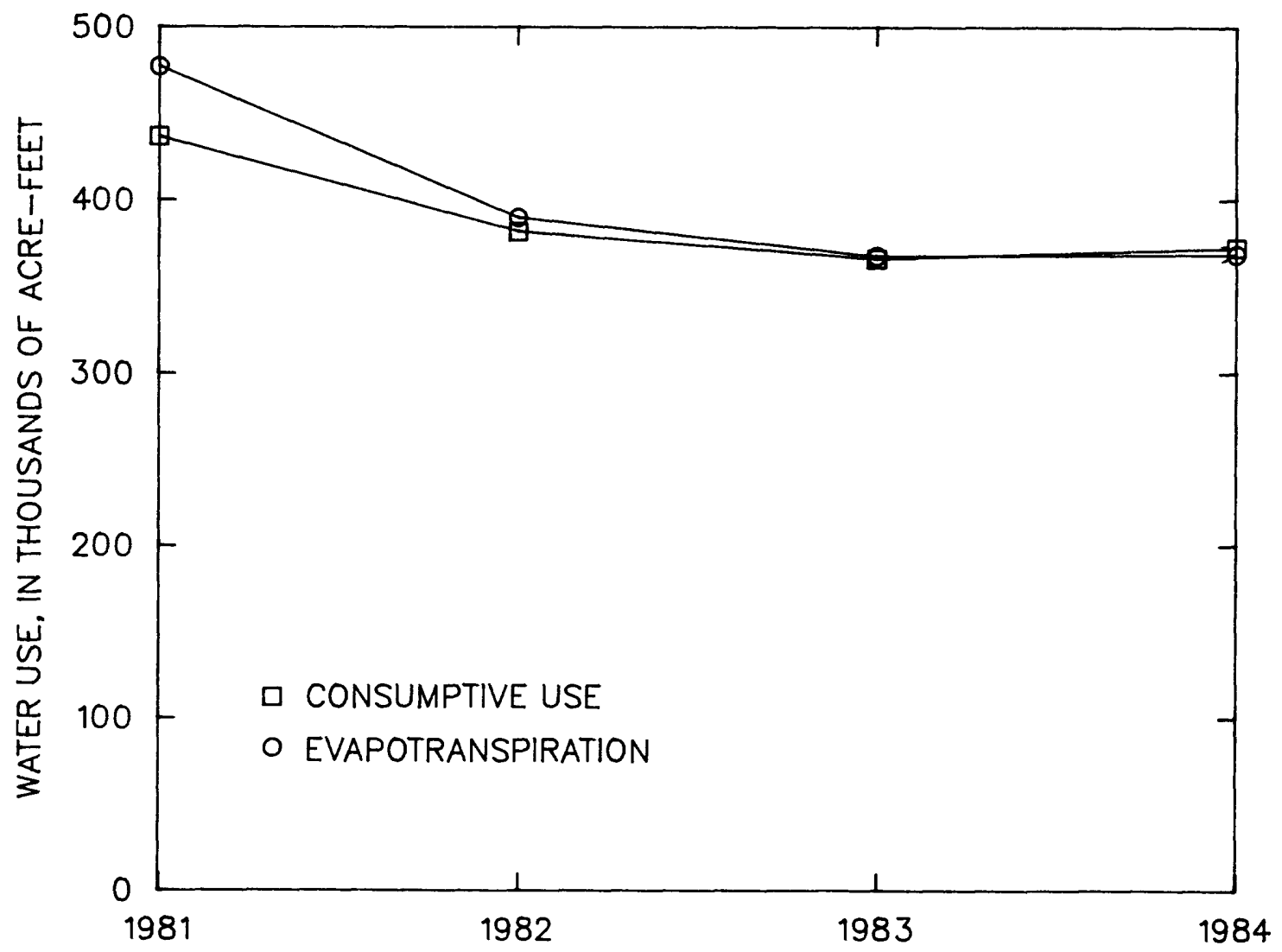

Figure 19.--Comparison of consumptive use by vegetation and evapotranspiration in Parker Valley, Arizona, 1981-84. 


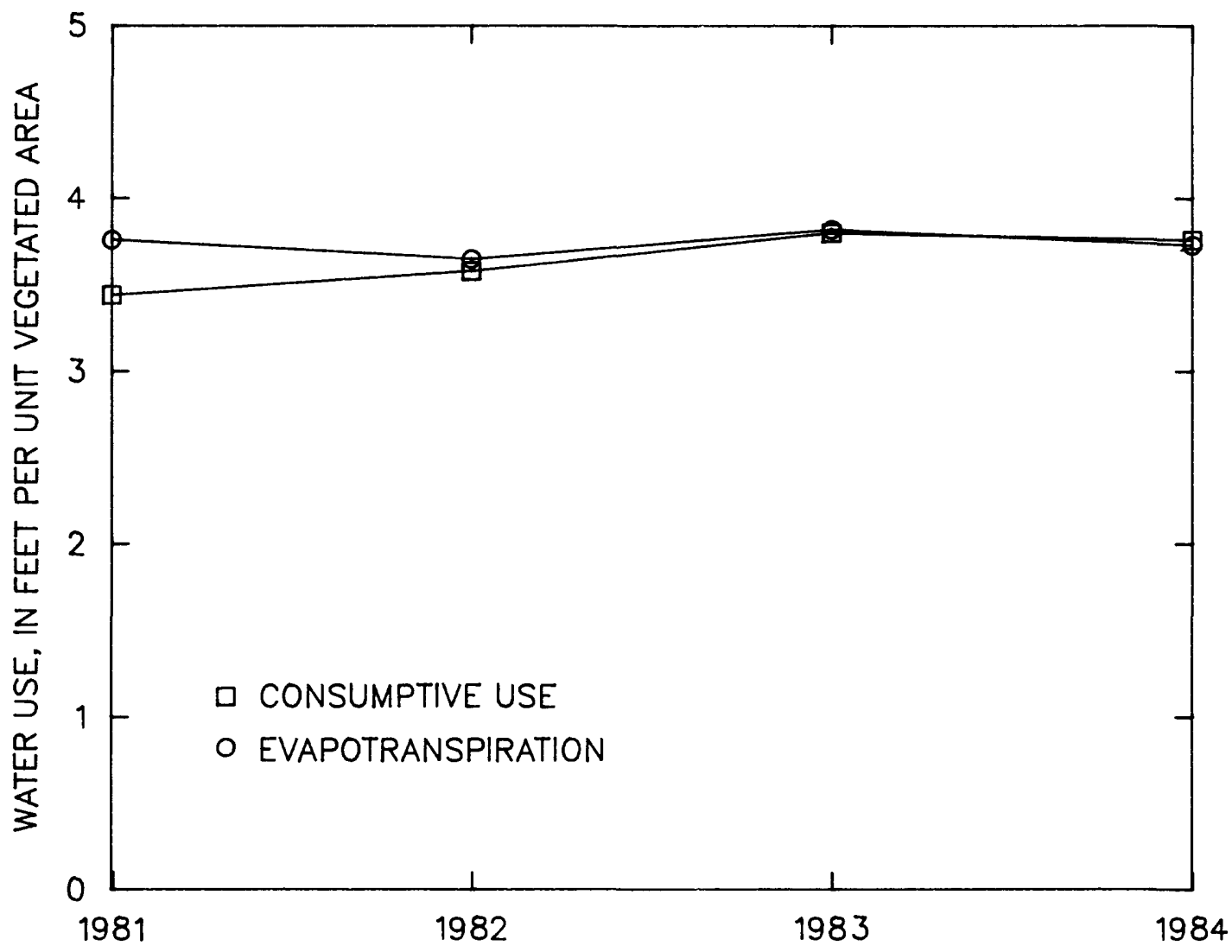

Figure 20.--Comparison of consumptive use by vegetation and evapotranspiration per unit vegetated area in Parker Valley, Arizona, 1981-84.

Percent differences between consumptive use by vegetation and evapotranspiration are within the measurement errors on the measured components. The estimates were within 2 percent for 1982 to 1984 and within 9 percent in 1981. Sensitivity analyses support the correlation and indicate that estimating consumptive use by vegetation is dependent on the accuracy with which the diversion at Headgate Rock Dam (within 5 percent) and the surface-water return flows (within 10 to 15 percent) are measured. An underestimation of the amount of seepage from the river entering the drainage ditches could result in an underestimation of consumptive use by vegetation. During all 4 years, evapotranspiration was greater than consumptive use by vegetation, which could indicate that evapotranspiration rates calculated using the Blaney-Criddle equation (Blaney and Criddle, 1950) may be too high. Evapotranspiration by phreatophytes was not calculated by using the Blaney-Criddle equation because empirical consumptive-use coefficients (K values) were not available for the phreatophyte mixture along the Colorado River. Evapotranspiration by phreatophytes is dependent on depth to water. The rise in river stage in 1983 and 1984 caused an increase in evapotranspiration during those years, which was not reflected in the evapotranspiration calculations. 
The area of Parker Valley south of Tyson Wash contains three separate agricultural areas, although most of the area is covered with phreatophytes (fig. 14). Two agricultural areas are on the Colorado River Indian Reservation. Water is delivered to the northernmost area from the diversion at Headgate Rock Dam. The two southern areas are supplied with water from pumps in the river and a well on the flood plain (table 13). Records for the crops grown in the northernmost area were available from the U.S. Bureau of Indian Affairs (table 14). Records of crop types were incomplete for the two southern areas; crop types and acreages were determined by using digital-image analysis of Landsat satellite images (L.H. Raymond, hydrologist, U.S. Geological Survey, written commun., 1987). Areas covered by phreatophytes were mapped from aerial photographs taken in August 1985 and then digitized.

Table 13.--Estimates of surface-water diversions to irrigated land south of Tyson Wash in Parker Valley, Arizona, 1981-84, in acre-feet per year

\begin{tabular}{|c|c|c|c|c|}
\hline & 1981 & 1982 & 1983 & 1984 \\
\hline $\begin{array}{l}\text { Water deliveries to that } \\
\text { part of Quail Mesa Ranch } \\
\text { south of Tyson Wash }{ }^{1}\end{array}$ & 4,863 & 4,940 & 4,215 & 4,204 \\
\hline \multicolumn{5}{|l|}{ Diversion $^{2}$ by: } \\
\hline $\begin{array}{l}\text { Colorado River Indian } \\
\text { Reservation pumps }\end{array}$ & 13,780 & 10,950 & 6,461 & 8,955 \\
\hline Clayton/Raynor pumps ${ }^{4}$ & 4,916 & 4,916 & 1,830 & 936 \\
\hline Clayton/Raynor we $11^{5}$ & 280 & 280 & 374 & 231 \\
\hline $\begin{array}{l}\text { Total diversion } \\
\text { (rounded) }\end{array}$ & 23,800 & 21,100 & 12,900 & 14,300 \\
\hline
\end{tabular}

${ }^{1}$ Estimated quantity reported by the U.S. Bureau of Indian Affairs (C.B. Kresge, written commun., 1987).

${ }^{2}$ U.S. Bureau of Reclamation (1982; 1984; 1985; 1986).

${ }^{3}$ About $3 \mathrm{mi}$ downstream from Palo Verde Dam.

${ }^{4}$ About $6.5 \mathrm{mi}$ downstream from Palo Verde Dam.

${ }^{5}$ Pumping from the flood-plain aquifer is considered use of Colorado River water. 
Table 14.- Areas by crop type south of Tyson Wash in Parker Valley, Arizona, 1981-84, in acres

Alfalfa Cotton Grains Bermuda

1981:

Quail Mesa Ranch ${ }^{1}$

Farm about $3 \mathrm{mi}$ south of Palo Verde Dam ${ }^{2}$

Clayton/Raynor Farm about $6.5 \mathrm{mi}$ south of $\mathrm{Palo}$

Verde Dam²

Total

263

142

100

418

816

208

219

$-\cdot$

601

183

$\underline{\cdots-}$

1,165

951

502

418

1982 :

Quail Mesa Ranch ${ }^{1}$

Farm about $3 \mathrm{mi}$ south of Palo Verde Dam ${ }^{2}$

211

99

171

442

Clayton/Raynor Farm about

$6.5 \mathrm{mi}$ south of Palo

Verde Dam²

562

306

43

52

395

218

Total

825

800

1,232

442

1983:

Quail Mesa Ranch ${ }^{1}$

Farm about $3 \mathrm{mi}$ south of

Palo Verde Dam ${ }^{2}$

332

-. $\quad 100$

491

Clayton/Raynor Farm about

$6.5 \mathrm{mi}$ south of Palo

Verde $\mathrm{Dam}^{2}$

662

139

70

$-\cdot-$

Total

$\frac{7}{1,001}$

276

9

$\underline{-\cdots}$

415

179

491

1984:

Quail Mesa Ranch ${ }^{1}$

Farm about $3 \mathrm{mi}$ south of

Palo Verde Dam ${ }^{2}$

487

164

$-\cdot-$

272

Clayton/Raynor Farm about

745

$-$

286

$6.5 \mathrm{mi}$ south of Palo

Verde Dam ${ }^{2}$

$\frac{\cdots}{1,232}$

469

48

$\underline{---}$

Total

633

334

272

${ }^{1}$ U.S. Bureau of Indian Affairs (C.B. Kresge, written commun., 1987).

${ }^{2}$ Crop types and areas from Landsat digital-image analys is (L.H. Raymond, U.S. Geological Survey, written commun., 1987). 
Consumptive use by vegetation for the area south of Tyson Wash was estimated as the product of vegetated area and consumptive use per unit vegetated area determined for the area north of Tyson Wash (table 15). Evapotranspiration by vegetation types was estimated as the product of vegetated area and evapotranspiration. Evapotranspiration was about 8 percent higher than consumptive use by vegetation in 1981. During the other 3 years, evapotranspiration was from 0.6 to 3 percent lower than consumptive use by vegetation. Similar to the area north of Tyson Wash, the percent differences in the two values were within 3 percent for 1982 to 1984 and within 8 percent in 1981.

\section{Area on the California Side of the River}

Consumptive use by vegetation for the flood-plain area on the California side of the river was computed as the product of the vegetated area and consumptive use per unit vegetated area determined for that part of the valley north of Tyson Wash (table 16). The flood plain on the California side of the river contains separate agricultural areas of which three showed about 600 acres of crops in the digital-image classification for 1984. Evapotranspiration for the crops was computed using the Blaney-Criddle equation. The rest of the flood-plain area was covered in phreatophytes, a mixture of mainly saltcedar and mesquite. Away from the river in Parker Valley, mesquite is the predominant phreatophyte; whereas adjacent to the river, a saltcedar-mesquite mixture was mapped by Anderson and Ohmart (1976). Saltcedar uses about twice as much water as mesquite; therefore, in the calculation of evapotranspiration on the California side of the river, the value of evapotranspiration per unit area for the reach below Palo Verde Dam was used because that reach contains saltcedar (Boyle Engineering Corp., 1976, p. II-7). A comparison of consumptive use by vegetation and evapotranspiration for the flood-plain area in California showed that the estimate of consumptive use by vegetation was 10 percent higher than the estimate of evapotranspiration.

\section{GROUND-WATER RETURN FLOW}

North of Tyson Wash, annual ground-water return flow to the river for 1981 to 1984 (table 17) was computed using water budgets (equation 4). Annual diversions to the area drained by the river (table 10) and consumptive use by vegetation were estimated as described in the section entitled "Consumptive Use." Water-budget calculations for ground-water return flow resulted in negative values for 1981, 1983, and 1984 (table 17); therefore, ground-water return flow was 0 acre-ft in 1981, 1983, and 1984, and 1,900 acre-ft in 1982. The negative values for ground-water return flow show that consumptive use exceeded the amount of water applied to the area drained by the river. Vegetation mainly phreatophytestranspired ground water, which was replaced by induced seepage from the river.

The negative values for ground-water return flow indicate that the use of annual average water-table-altitude maps to delineate the area drained by the river can be misleading if there are insufficient data 
Table 15.--Estimates of evapotranspiration and consumptive use by vegetation south of Tyson Wash in Parker Valley, Arizona, 1981-84

$\begin{array}{ccccc}\text { Evapotran- } & \text { Consumptive } & \text { Area, } & \text { Evapotran- } & \text { Consumptive } \\ \text { spiration, } & \text { use, in } & \text { in } & \text { spiration, } & \text { use, in } \\ \text { in feet } & \text { feet }^{1} & \text { acres in acre-feet } & \text { acre-feet }\end{array}$

1981:

\begin{tabular}{lrrrrr} 
Alfalfa & 26.86 & 3.44 & 1,165 & 7,992 & 4,008 \\
Cotton & 23.77 & 3.44 & 951 & 3,585 & 3,271 \\
Grains & 22.45 & 3.44 & 502 & 1,230 & 1,727 \\
Bermuda & 24.34 & 3.44 & $\frac{418}{3,036}$ & $\frac{1,814}{14,621}$ & $\underline{1,438}$ \\
$\quad$ Subtotal & & & $\underline{9,980}$ & $\underline{33,932}$ & $\underline{34,331}$ \\
Phreatophytes & 33.4 & 3.44 & $\underline{9,000}$ & 48,600 & 44,800 \\
\multicolumn{2}{l}{ Total (rounded) } & & 13,000
\end{tabular}

1982:

$\begin{array}{lll}\text { Alfalfa } & 26.66 & 3.58 \\ \text { Cotton } & 23.65 & 3.58 \\ \text { Grains } & 22.40 & 3.58 \\ \text { Bermuda } & 24.20 & 3.58 \\ \quad \text { Subtotal } & & \\ \text { Phreatophytes } & 33.4 & 3.58\end{array}$

Total (rounded)

\begin{tabular}{rrr}
825 & 5,495 & 2,954 \\
800 & 2,920 & 2,864 \\
1,232 & 2,957 & 4,411 \\
442 & 1,856 & $\frac{1,582}{12,811}$ \\
\hline 3,299 & $\frac{35,728}{13,228}$ & $\underline{33,932}$ \\
\hline, 980 & $\underline{3}$ & 48,500
\end{tabular}

1983:

$\begin{array}{lll}\text { Alfalfa } & 26.69 & 3.80 \\ \text { Cotton } & 23.69 & 3.80 \\ \text { Grains } & 22.36 & 3.80 \\ \text { Bermuda } & 24.22 & 3.80 \\ \quad \text { Subtotal } & & \\ \text { Phreatophytes } & 33.4 & 3.80\end{array}$

Total (rounded)

3.58

3.58

3.58

3.58

13,300

1,001

415

179

491

2,086

9,980

6,697

1,531

422

$\frac{2,072}{10,722}$

1,577

680

$\frac{1,866}{7,927}$

37, 924

12,100

44,700

45,900

1984:

$\begin{array}{lrrrrr}\text { Alfalfa } & 26.75 & 3.76 & 1,232 & 8,316 & 4,632 \\ \text { Cotton } & 23.67 & 3.76 & 633 & 2,323 & 2,380 \\ \text { Grains } & 22.42 & 3.76 & 334 & 808 & 1,256 \\ \text { Bermuda } & 24.24 & 3.76 & \underline{272} & \frac{1,153}{12,600} & \frac{1,023}{9,291} \\ \quad \text { Subtotal } & & & \underline{2,471} & \underline{33,932} & \underline{37,525} \\ \text { Phreatophytes } & 3.4 & 3.76 & \underline{9,980} & \\ \quad & & 12,500 & 46,500 & 46,800\end{array}$

${ }^{1}$ Consumptive use calculated for the area north of Tyson Wash (table 8).

${ }^{2}$ Determined using the Blaney-Criddle equation and temperature data from Ehrenberg, Arizona (Blaney and Criddle, 1950).

${ }^{3}$ Boyle Engineering Corp. (1976, p. II-7). 
Table 16.--Estimates of evapotranspiration and consumptive use by vegetation on the California side of the river in Parker Valley. Arizona, 1984

$\begin{array}{ccccc}\text { Evapotran- } & \text { Consumptive } & \text { Area, } & \text { Evapotran- } & \text { Consumptive } \\ \text { spiration, } & \text { use, in } & \text { in } & \text { spiration, } & \text { use, in } \\ \text { in feet } & \text { feet }^{1} & \text { acres in acre-feet } & \text { acre-feet }\end{array}$

1984:

\begin{tabular}{lrrrrr}
$\begin{array}{l}\text { Alfalfa } \\
\text { Cotton }\end{array}$ & 26.67 & 3.76 & 46 & 307 & 173 \\
$\quad 23.63$ & 3.76 & $\underline{561}$ & $\underline{2.036}$ & $\underline{2.109}$ \\
$\quad$ Subtotal & & & 607 & 2,343 & 2,282 \\
Phreatophytes & 3.4 & 3.76 & $\underline{11.005}$ & $\underline{37.417}$ & $\underline{41.379}$ \\
\multicolumn{2}{l}{ Total (rounded) } & & 11,600 & 39,800 & 43,700
\end{tabular}
(table 8).

${ }^{1}$ Consumptive use calculated for the area north of Tyson Wash

${ }^{2}$ Determined using the Blaney-Criddle equation and temperature data from Parker, Arizona (Blaney and Criddle, 1950).

${ }^{3}$ Boyle Engineering Corp. (1976, p. II-7). Used the evapotranspiration for the area south of Palo Verde Dam because the vegetation maps of Anderson and Ohmart (1976) show substantial amounts of a saltcedar-mesquite mixture along the river on the California side, which is more characteristic of the area south of Palo Verde Dam.

points within $0.5 \mathrm{mi}$ of the river, particularly in dense phreatophyte areas. The configuration of the water table under the fields can indicate that ground water flows toward the river, when actually it is flowing into the area of phreatophytes that line an old meander channel. Here, the ground water is being consumed by the phreatophytes and is not returning to the main river channel; therefore, ground-water return flow is not available for use downstream. The ground-water return flow drained into an area of backwater that was created when the rise in river stage filled the old meander channel. The quantity of ground water that flows toward the river is insufficient for the phreatophytes; therefore, the use of additional ground water from the shallow aquifer results in induced seepage from the river, a naturally occurring but unmeasured diversion from the river.

The negative values for ground-water return flow support the assessment that seepage from the river was underestimated. Seepage from the river can be a component in the water budget to estimate ground-water return flow. A negative value for ground-water return flow is an estimate of river seepage as an inflow component (natural diversion) in the area drained by the river. 
Table 17. - -Water budgets for the area drained by the Colorado River in Parker Valley, Arizona, 1981-84, in acre-feet per year

\begin{tabular}{|c|c|c|c|c|}
\hline & 1981 & 1982 & 1983 & 1984 \\
\hline \multicolumn{5}{|l|}{ Inflow: } \\
\hline $\begin{array}{l}\text { Surface-water diversion.... } \\
\text { Effective precipitation... }\end{array}$ & $\begin{array}{r}35,000 \\
4,400 \\
\end{array}$ & $\begin{array}{r}46,600 \\
5,900 \\
\end{array}$ & $\begin{array}{r}24,500 \\
4,100 \\
\end{array}$ & $\begin{array}{r}23,100 \\
2.700 \\
\end{array}$ \\
\hline Total ....... & $\underline{\underline{39.400}}$ & $\underline{\underline{52,500}}$ & $\underline{\underline{28,600}}$ & $\underline{\underline{25,800}}$ \\
\hline \multicolumn{5}{|l|}{ Outflow: } \\
\hline $\begin{array}{l}\text { Consumptive use by } \\
\text { vegetation }{ }^{1} \ldots \ldots \ldots \ldots \ldots \\
\text { Unmeasured ground-water } \\
\text { return flow to the } \\
\text { river }{ }^{2} \ldots \ldots \ldots \ldots \ldots \ldots\end{array}$ & 48,800 & 50,600 & 41,600 & 39,400 \\
\hline Total (rounded).... & $\underline{\underline{39.400}}$ & $\underline{\underline{52,500}}$ & $\underline{\underline{24,000}}$ & $\underline{\underline{23}, 200}$ \\
\hline Change in storage: & $\left({ }^{3}\right)$ & $\left({ }^{3}\right)$ & 4,600 & 2,600 \\
\hline
\end{tabular}

${ }^{1}$ From table 8.

${ }^{2}$ Unmeasured ground-water return flow to the river was calculated as inflow minus other outflows minus change in storage.

${ }^{3} \mathrm{Negligible.}$

A sensitivity analysis was done to determine the change in computed ground-water return flow to the river for a specified change in value of a primary variable. The sensitivity values for ground-water return flow (table 12) indicate that ground-water return flow is most sensitive to the diversion at Headgate Rock Dam, discharge from drainage ditches to the river, evapotranspiration by phreatophytes, the area of phreatophytes west of the divide, and irrigation requirements for alfalfa and cotton. The diversion and the discharge from drainage ditches are significant components in the calculation of consumptive use by vegetation; therefore, ground-water return flow is sensitive also to consumptive use by vegetation.

An area-weighted average of empirically determined evapotranspiration by species of phreatophytes was the only available estimate of evapotranspiration by phreatophytes. Additional work is needed to provide data by which estimates of evapotranspiration by phreatophytes would be equivalent in resolution to the evapotranspiration values for the various crops. Evapotranspiration by phreatophytes also needs to be varied to reflect year-to-year changes in weather conditions as well as year-to-year changes in depth to water. The estimate of ground-water return flow is sensitive to evapotranspiration by phreatophytes because phreatophytes cover 70 to 80 percent of the area drained by the river. 
South of Tyson Wash, none of the water diverted to irrigate croplands returns to the river. Ground water flows away from the river (fig. 14) and consumptive use by vegetation ranges from 1.9 to 3.6 times the amount of water diverted (tables 13 and 15). Consumptive use by crops is less than the diversion but any return flow from the applied water flows away from the river and into areas of phreatophytes where it is consumed. Additional water consumptively used by phreatophytes is obtained from ground water in the shallow aquifer, which is replaced by induced seepage from the river.

On the California side of the river, a relation similar to that south of Tyson Wash occurs; consumptive use by crops (table 16) is less than the diversion (table 2) but large quantities of phreatophytes consume more than eight times the diversion. Any return flow from the applied water is consumed by the phreatophytes. Phreatophytes obtain the rest of their water supply from ground water and induced seepage from the river into the aquifer.

\section{DIVERSIONS MINUS RETURN FLOWS}

In a decree by the U.S. Supreme Court (1964), the United States is required to account for the consumptive use of lower Colorado River water on a calendar-year basis. The quantity of water diverted from the river at Headgate Rock Dam is gaged. In 1981 additional water was pumped from the river to irrigate land about $1 \mathrm{mi}$ upstream from Palo verde Dam; beginning in 1982, this land was irrigated with water from the Headgate Rock Dam diversion. Water diverted at Headgate Rock Dam is applied to irrigated land north of Tyson Wash. Surface-water return flows are computed from measurements and (or) gaging-station records, and groundwater return flows are estimated by using the water-budget method as modified from Leake (1984). Estimated consumptive use of Colorado River water calculated as diversions minus return flows assumes that the source of all flow in the drainage ditches is the measured diversions mentioned above. Agriculture is the primary use of Colorado River water in Parker Valley, but some return flows moving through the alluvium are intercepted by domestic pumping and phreatophytes. Quantities of measured diversions, return flows, and consumptive use of river water calculated as diversions minus return flows for 1981 to 1984 for the area north of Tyson Wash are itemized in the following list:

\begin{tabular}{lrrrr} 
& \multicolumn{3}{c}{ Quantity, in acre-feet } \\
\cline { 2 - 5 } & $\underline{1981}$ & $\underline{1982}$ & $\underline{1983}$ & $\underline{1984}$ \\
Surface-water diversion & 609,600 & 566,300 & 539,500 & 584,800 \\
Surface-water return flow & 240,500 & 244,600 & 266,700 & 312,400 \\
$\begin{array}{l}\text { Ground-water return flow } \\
\text { Consumptive use (diversions }\end{array}$ & 0 & 1,900 & 0 & 0 \\
$\quad$ minus return flows) & 369,100 & 319,800 & 272,800 & 272,400
\end{tabular}

In the area south of Tyson Wash and on the California side of the river, all the measured diversion is presumed to be consumptively used, because there are no return flows. Any potential ground-water return flow 
is consumptively used by the phreatophytes. The consumptive use exceeds the diversion because the phreatophytes alone use more water than is diverted to the croplands. Phreatophytes transpire river water, which is obtained from the shallow alluvial aquifer through induced river seepage into the aquifer.

\section{COMPARISON OF CONSUMPTIVE-USE ESTIMATES}

The comparison of consumptive use by vegetation calculated from a water budget to consumptive use of river water calculated as diversions minus return flows helps to show that the method using measured diversions minus return flows may result in an underestimation of consumptive use of river water in Parker Valley. Consumptive use by vegetation calculated from a water budget is not equivalent to consumptive use of river water calculated as measured diversions minus return flows. Consumptive use by vegetation is a major part of the consumptive use of river water; however, the consumptive use by vegetation on the flood plain does not include the ground water pumped and consumptively used for domestic and municipal supplies. If total ground-water pumpage were consumed, the water-budget estimate of consumptive use would increase by that amount, and the difference between the two estimates of consumptive use also would increase by that amount.

The estimate of consumptive use of Colorado River water using measured diversions minus return flows was consistently lower-from 18 to 37 percent lower - than consumptive use by vegetation (fig. 21). The difference between the two estimates ranged year to year from 61,900 to 100,000 acre-ft. The differences were greatest during the years of high flow in the river suggesting a connection to the increase in river seepage, which moves through the alluvium and into the drainage ditches. Tributary runoff and ground-water inflows in the drainage ditches cannot be measured and were not considered part of the diversion; this may account for the differences in years when flow in the river is regulated to meet downstream requirements.

Consumptive use of Colorado River water calculated as measured diversions minus return flows was consistently low because this method does not include the effects caused by variations in tributary inflow or river stage. Average annual values of tributary surface-water and ground-water inflows were used in the water-budget calculations because rainfall is infrequent and produces short duration and extremely variable runoff that occurs only about once a year. Surface-water flows range from zero to many times the long-term annual average. Ground-water inflow to the shallow alluvial aquifer mixes with the water recharged from irrigation and is difficult to quantify (Owen-Joyce, 1987). In years of above-average precipitation that generate tributary runoff in excess of the average value used in these calculations, the tributary runoff flows into drainage ditches and is measured and credited as surface-water return flows. Tributary ground-water inflow also is captured in drainage ditches and measured as surface-water return flows. Changes in river stage affect the quantity of water moving through the aquifer that originates as seepage from the river. During periods of high river stage, larger quantities of river seepage result in increased bank storage, increased captured river 


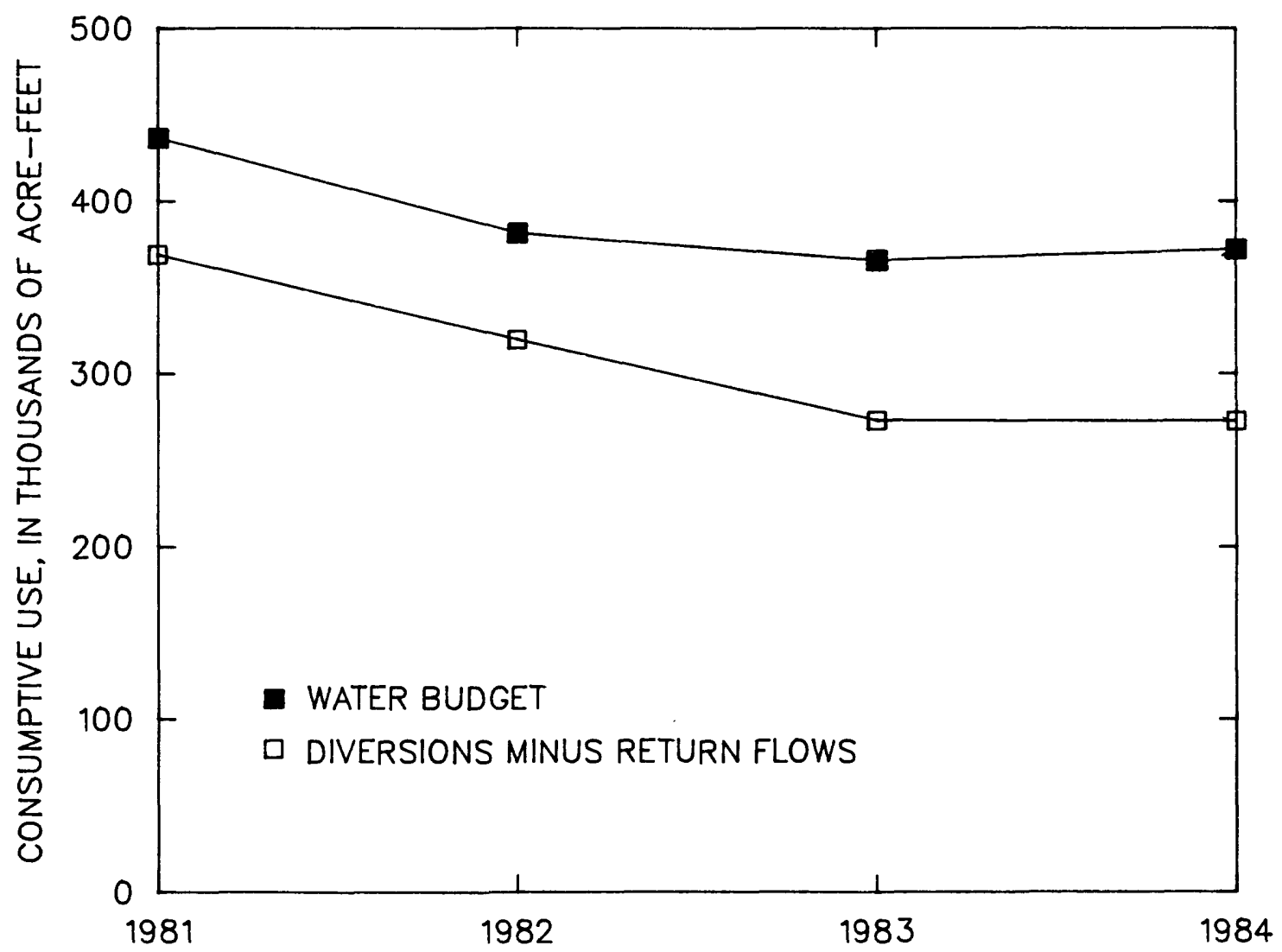

Figure 21.--Comparison of consumptive use by vegetation determined from a water budget and consumptive use of Colorado River water determined from diversions minus return flows in Parker Valley, Arizona, 1981-84.

seepage in the drainage ditches, and a backwater effect on irrigation return flow in the drainage ditches and in the aquifer along the drainage ditches. Captured river seepage in the drainage ditches is not accounted for in the diversion of Colorado River water but is measured and credited as surface-water return flows from that diversion. Overestimating surfacewater return flows results in underestimating the consumptive use of river water. The response time to changes in river stage that occur late in the year may be significant in delaying part of the effects into the next calendar year. These changes in ground-water storage are not accounted for in the calculation of measured diversions minus return flows.

\section{SUMMARY}

North of Tyson Wash, Parker Valley can be divided into two ground-water drainage areas, one where ground water drains into drainage ditches and another where ground water drains to the river. A ground-water 
divide between the river and the drainage ditch nearest the river separates the two drainage areas. Diversions and surface-water return flows are measured. Consumptive use by vegetation (crops and phreatophytes) can be estimated by using a water budget for the area drained by drainage ditches. Inflow components are (1) surface-water diversion, (2) effective precipitation, (3) ground-water inflow and tributary runoff from the area east of the flood plain, and (4) seepage from the river. Outflow components are (1) surface-water discharge to the river from drainage ditches, (2) consumptive use by vegetation, and (3) pumpage. Change in storage could not be calculated for the area drained by drainage ditches because water-level data were not available. Change in storage was assumed to be negligible as was shown in a similar study for Palo Verde Valley. Consumptive use per unit vegetated area from the area east of the divide was used to estimate consumptive use by vegetation for the vegetated area west of the divide. Consumptive use per unit vegetated area for the area north of Tyson Wash was used to estimate consumptive use by vegetation south of Tyson Wash and on the California side of the river. Total consumptive use by vegetation is the sum of consumptive use by vegetation east and west of the divide, south of Tyson Wash, and on the California side of the river.

Annual water budgets were used to determine consumptive use by vegetation and ground-water return flow from 1981 to 1984 . Consumptive use by vegetation in Parker Valley on the Arizona side of the river was 482,800 acre-ft in $1981,432,000$ acre-ft in 1982, 413,500 acre-ft in 1983, and 420,900 acre-ft in 1984. In 1984, consumptive use by vegetation in Parker Valley on the California side of the river was 45,400 acre-ft. Sensitivity analyses of the primary variables used in the computation of consumptive use by vegetation north of Tyson Wash show that variations in computed consumptive use by vegetation are most sensitive to two measured components - the diversion at Headgate Rock Dam and the discharge from drainage ditches to the river. Ground-water return flow was estimated to be 0 acre-ft in 1981, 1983, and 1984 and 1,900 acre-ft in 1982. Sensitivity analyses indicate that variations in computed grcund-water return flow to the river north of Tyson Wash are most sensitive to the diversion at Headgate Rock Dam, discharge from drainage ditches to the river, consumptive use by vegetation, evapotranspiration by phreatophytes, the area of phreatophytes west of the divide, and irrigation requirements for alfalfa and cotton. None of the diverted water returns to the river south of Tyson Wash and on the California side of the river. In these areas, consumptive use by phreatophytes exceeds the diversions. Phreatophytes intercept and use any return flows from the diversions and also use ground water, which is replaced with induced seepage from the river.

Maps that show annual average change in ground-water levels were used to calculate change in ground-water storage in the area drained by the river. Adjacent to the river, water-level changes were caused by changes in river stage. In the area east of Palo Verde drain, variations in the amount of irrigation caused water-level changes. From 1982 to 1984 , changes in water levels in the area drained by the river ranged from -0.40 to $3.94 \mathrm{ft}$. The change in storage was 4,600 acre-ft in 1983 and 2,600 acre-ft in 1984. Change in ground-water storage can be a significant component in a water budget to estimate ground-water return flow.

Two methods of estimating water use by vegetation were used and compared during this study. Whether consumptive use by vegetation was 
estimated with a water budget or evapotranspiration was estimated as the product of vegetated area and evapotranspiration, the relation between the two estimates remained within 2 percent from 1982 to 1984 in all three areas. In 1981 the two estimates were within 9 percent. Regardless of differences in year-to-year conditions, the percentage differences in the two estimates were within the measurement error of the two major measured components in the water budget. Sensitivity analyses support the correlation and indicate that the estimate of consumptive use by vegetation is dependent on the accuracy with which the diversion (within 5 percent) and surface-water return flows (within 10 to 15 percent) are measured.

In a comparison, estimates of evapotranspiration generally were higher than estimates of consumptive use by vegetation. Estimates of evapotranspiration were from 1 percent lower to 9 percent higher than estimates of consumptive use by vegetation for the area north of Tyson Wash. For 3 of the 4 years studied, the estimates of evapotranspiration were within 2 percent of the estimates of consumptive use by vegetation. South of Tyson Wash, estimates of evapotranspiration ranged from 3 percent lower to 8 percent higher than estimates of consumptive use by vegetation. On the California side of the river, the estimate of consumptive use by vegetation was 10 percent higher than the estimate of evapotranspiration.

Consumptive use of Colorado River water calculated as measured diversions minus surface-water and ground-water return flows was consistently lower than the estimate of consumptive use by vegetation. The effects caused by variations in tributary inflow and river stage were not considered in the calculation of diversions minus return flows. Estimates of consumptive use of Colorado River water were from 18 to 37 percent lower than estimates of consumptive use by vegetation. Water-budget estimates of consumptive use by vegetation that account for tributary inflow as an inflow component offset any tributary water in the drains that is measured as surface-water return flows. Tributary inflow captured in the drains is measured and credited as surface-water return flows from the diversion at Headgate Rock Dam in the diversion-minus-return-flows method. Captured river seepage in the drains is not accounted for in the diversion of Colorado River water but is measured and credited as surface-water return flows. Induced seepage from the river, which is consumptively used by phreatophytes, is not accounted for as a diversion.

\section{SELECTED REFERENCES}

Anderson, B.W., and Ohmart, R.D., 1976, Vegetation type maps of the lower Colorado River from Davis Dam to southerly international boundary: Phoenix, Arizona State University duplicated report, 4 p., 23 pls.

Blaney, H.F., and Criddle, W.D., 1950, Determining water requirements in irrigated areas from climatological and irrigation data: U.S. Department of Agriculture, Soil Conservation Service, Technical Paper $96,48 \mathrm{p}$.

Bookman-Edmonston Engineering, Inc., 1976, Reduction of salt loading to the Colorado River from Palo Verde Irrigation District: Glendale, California, Report prepared for U.S. Bureau of Reclamation, $75 \mathrm{p}$. 
Boyle Engineering Corp., 1976, Salinity control and irrigation system analysis, Colorado River Indian Reservation, Yuma County, Arizona: Phoenix, Report prepared for U.S. Bureau of Reclamation, 267 p.

Leake, S.A., 1984, A method for estimating ground-water return flow to the Colorado River in the Parker area, Arizona and California: U.S. Geological Survey Water-Resources Investigations Report 84-4229, $31 \mathrm{p}$.

Metzger, D.G., and Loeltz, O.J., 1973, Geohydrology of the Needles area, Arizona, California, and Nevada: U.S. Geological Survey Professional Paper 486-J, 54 p.

Metzger, D.G., Loeltz, O.J., and Irelan, Burdge, 1973, Geohydrology of the Parker-Blythe-Cibola area, Arizona and California: U.S. Geological Survey Professional Paper 486-G, 130 p.

National Climatic Data Center, 1980-84, Climatological data, Arizona: U.S. Department of Commerce (published monthly).

Owen-Joyce, S.J., 1984, A method for estimating ground-water return flow to the Colorado River in the Palo Verde-Cibola area, California and Arizona: U.S. Geological Survey Water-Resources Investigations Report 84-4236, 48 p.

1987, Estimates of average annual tributary inflow to the lower Colorado River, Hoover Dam to Mexico: U.S. Geological Survey Water-Resources Investigations Report 87-4078, 1 sheet.

Owen-Joyce, S.J., and Kimsey, S.L., 1987, Estimates of consumptive use and ground-water return flow using water budgets in Palo Verde Valley, California: U.S. Geological Survey Water-Resources Investigations Report 87-4070, 50 p.

Raymond, L.H., and Owen-Joyce, S.J., 1986, Estimates of consumptive use and evapotranspiration in Palo Verde Valley, 1981 and 1983, in Johnson, A.I., and Rango, A., eds., Remote Sensing Applications for Consumptive Use (Evapotranspiration): American Water Resources Association Monograph Series No. 6, p. 25-34.

1987, Comparison of estimates of evapotranspiration and consumptive use in Palo Verde Valley, California: U.S. Geological Survey Water-Resources Investigations Report 87-4071, 27 p.

Raymond, L.H., and Rezin, K.V., 1986, Evapotranspiration estimates using remote-sensing data, Parker and Palo Verde Valleys, Arizona and California: U.S. Geological Survey Open-File Report 86-67, 33 p.

Sellers, W.D., and Hi11, R.H., eds., 1974, Arizona C1imate 1931-1972: Tucson, University of Arizona Press, 616 p.

U.S. Bureau of Reclamation, 1982, Compilation of records in accordance with Article $V$ of the Decree of the Supreme Court of the United States in Arizona v. California dated March 9, 1964, calendar year 1981: U.S. Bureau of Reclamation duplicated report, $44 \mathrm{p}$. 
1984, Compilation of records in accordance with Article $V$ of the Decree of the Supreme Court of the United States in Arizona $v$. California dated March 9, 1964, calendar year 1982: U.S. Bureau of Reclamation duplicated report, $37 \mathrm{p}$.

1985, Compilation of records in accordance with Article $V$ of the Decree of the Supreme Court of the United States in Arizona $v$. California dated March 9, 1964, calendar year 1983: U.S. Bureau of Reclamation duplicated report, $35 \mathrm{p}$.

1986, Compilation of records in accordance with Article V of the Decree of the Supreme Court of the United States in Arizona v. California dated March 9, 1964, calendar year 1984: U.S. Bureau of Reclamation duplicated report, $34 \mathrm{p}$.

U.S. Supreme Court, 1964, State of Arizona, plaintiff v. State of California, et al., defendants: U.S. Supreme Court DecreeMarch 9, 1964, no. 8, origina1, 14 p. 